Prepared in cooperation with the Missouri Department of Transportation

\title{
Bathymetric and Velocimetric Surveys at Highway Bridges Crossing the Missouri River between Kansas City and St. Louis, Missouri, April-May 2013
}

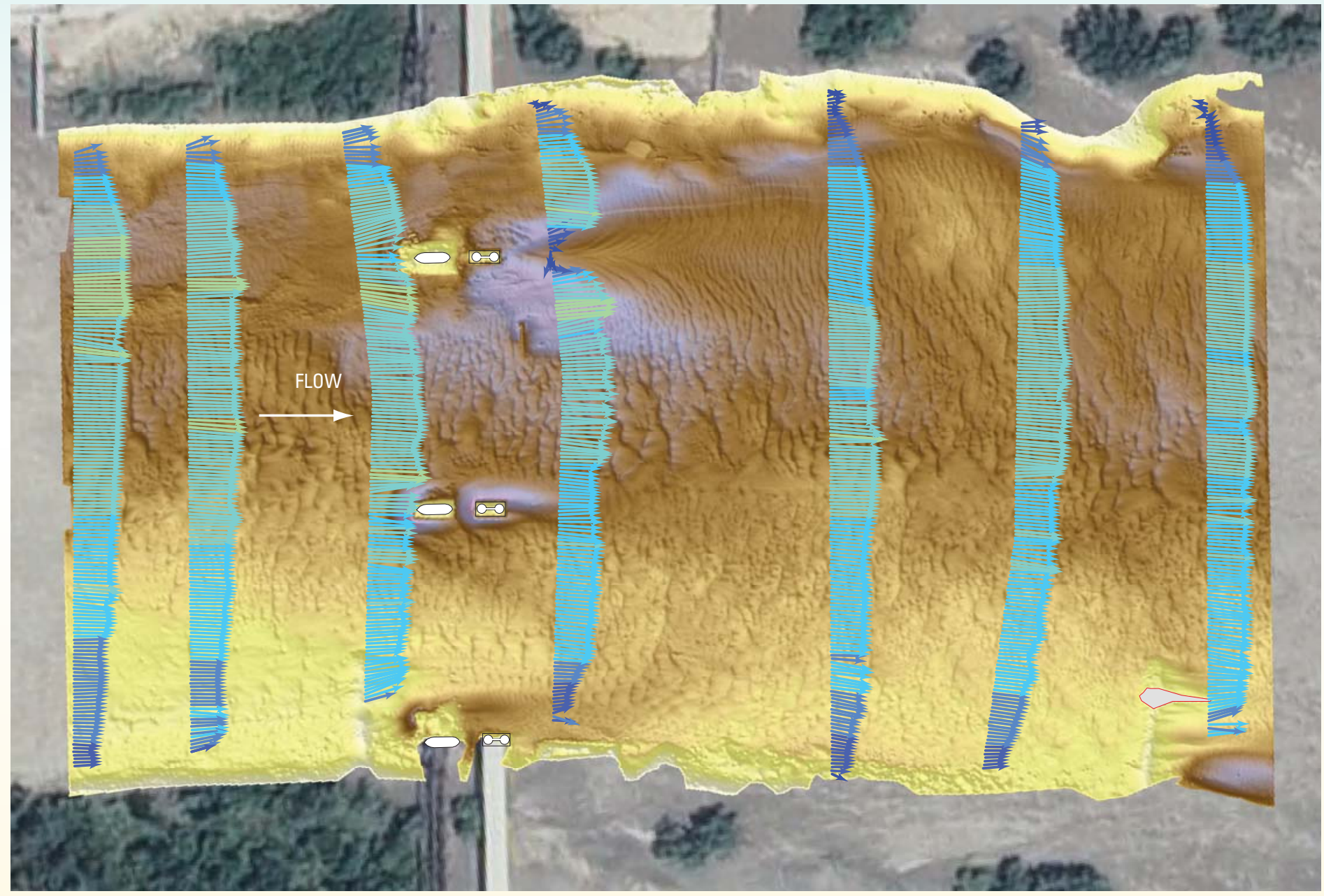

Scientific Investigations Report 2014-5116 
Front cover. Bathymetry and vertically averaged velocities of the Missouri River channel in the vicinity of structure G0069 on State Highway 240 at Glasgow, Missouri.

Back cover. Top: Visualizations of the channel bed and right (west) side of main channel pier 2 of structure G0069 on State Highway 240 and the upstream railroad bridge pier over the Missouri River at Glasgow, Missouri, as a $A$, point cloud, and $B$, shaded triangulated irregular network (TIN).

Bottom: The U.S. Geological Survey boat preparing for the bathymetric and velocimetric survey at structure A5910 on U.S. Highway 24 over the Missouri River at Waverly, Missouri, on April 25, 2013. 


\section{Bathymetric and Velocimetric Surveys at Highway Bridges Crossing the Missouri River between Kansas City and St. Louis, Missouri, April-May 2013}

By Richard J. Huizinga

Prepared in cooperation with the Missouri Department of Transportation

Scientific Investigations Report 2014-5116 


\title{
U.S. Department of the Interior SALLY JEWELL, Secretary
}

\section{U.S. Geological Survey Suzette M. Kimball, Acting Director}

\author{
U.S. Geological Survey, Reston, Virginia: 2014
}

For more information on the USGS - the Federal source for science about the Earth, its natural and living resources, natural hazards, and the environment, visit http://www.usgs.gov or call 1-888-ASK-USGS.

For an overview of USGS information products, including maps, imagery, and publications, visit http://www.usgs.gov/pubprod

To order this and other USGS information products, visit http://store.usgs.gov

Any use of trade, firm, or product names is for descriptive purposes only and does not imply endorsement by the U.S. Government.

Although this information product, for the most part, is in the public domain, it also may contain copyrighted materials as noted in the text. Permission to reproduce copyrighted items must be secured from the copyright owner.

Suggested citation:

Huizinga, R.J., 2014, Bathymetric and velocimetric surveys at highway bridges crossing the Missouri River between Kansas City and St. Louis, Missouri, April-May, 2013: U.S. Geological Survey Scientific Investigations Report 2014-5116, 79 p., http://dx.doi.org/10.3133/sir20145116.

ISSN 2328-0328 (online) 


\section{Contents}

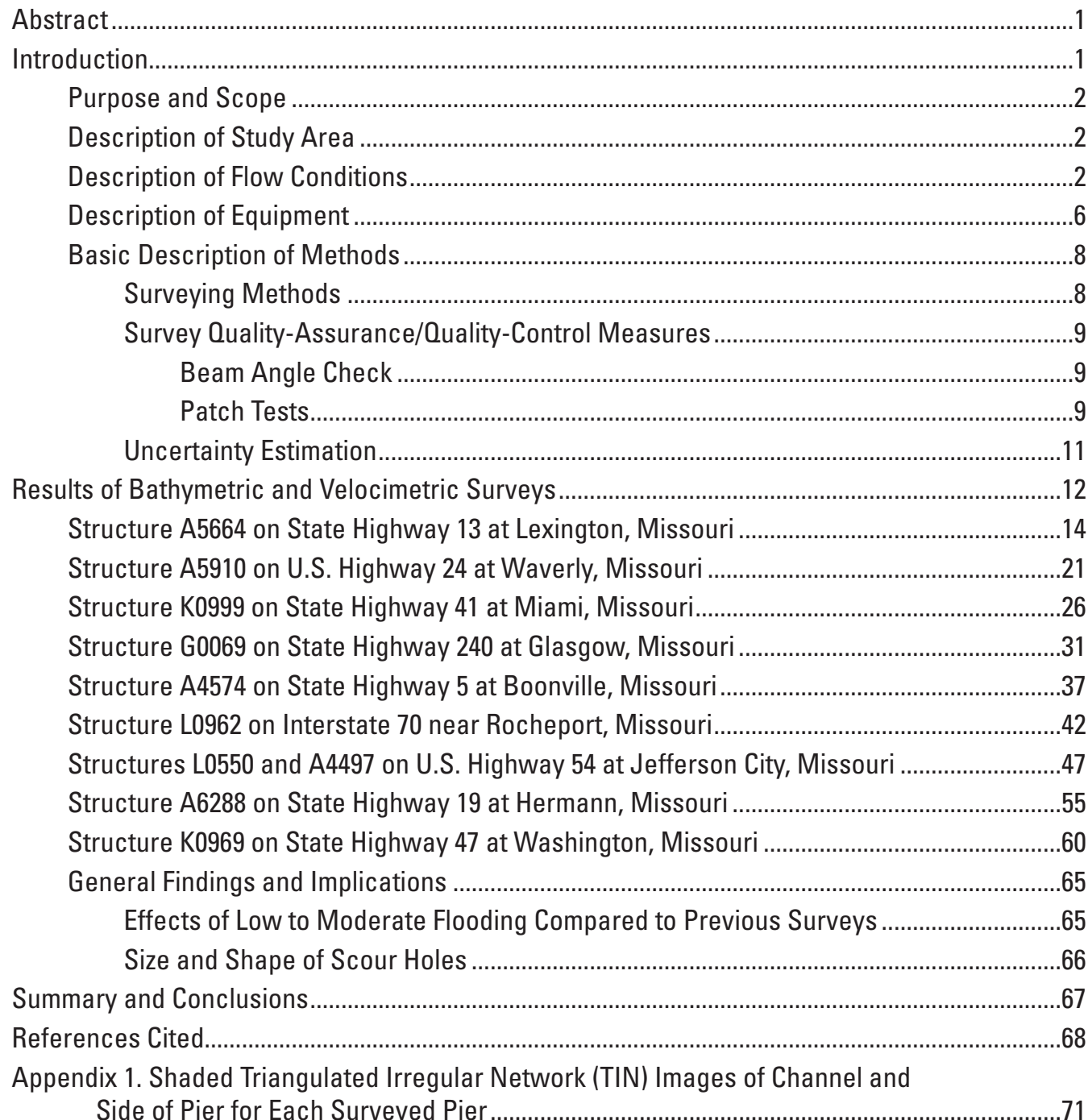

\section{Figures}

1. Map showing location of highway bridges across the Missouri River in and into Missouri, and bathymetric surveys on the Missouri River channel from April 22 through May 2, 2013

2. Graph showing unit values of discharge at selected streamflow-gaging stations in the study area on the Missouri River between Kansas City and St. Louis, Missouri, from April 17 through May 9, 2013.

3. Photographs showing the Teledyne RESON SeaBat ${ }^{\circledR} 7125-\mathrm{SV} 2$ multibeam echosounder, as viewed from the bottom, and mounted on the port side of the U.S. Geological Survey boat.

4. Illustration showing effects of timing offset for latency; and angular offsets for roll, pitch, and yaw on data from a multibeam echosounder. 
5. Map showing total propagated uncertainty of bathymetric data from the Missouri River channel in the vicinity of structure A6288 on Missouri Highway 19 at Hermann, Missouri

6. Map showing bathymetric survey of the Missouri River channel in the vicinity of structure A5664 on State Highway 13 at Lexington, Missouri.

7. Profile showing key features, substructural and superstructural details, and surveyed channel bed of structure A5664 on State Highway 13 over the Missouri River at Lexington, Missouri ......

8. Map showing difference between bathymetric surfaces created from surveys of the Missouri River channel in the vicinity of structure A5664 on State Highway 13 at Lexington, Missouri, on April 24, 2013, and July 20, 2011

9. Map showing bathymetry and vertically averaged velocities of the Missouri River channel in the vicinity of structure A5664 on State Highway 13 at Lexington, Missouri

10. Map showing bathymetric survey of the Missouri River channel in the vicinity of structure A5910 on U.S. Highway 24 at Waverly, Missouri..

11. Profile showing key features, substructural and superstructural details, and surveyed channel bed of structure A5910 on U.S. Highway 24 over the Missouri River at Waverly, Missouri.

12. Map showing difference between bathymetric surfaces created from surveys of the Missouri River channel in the vicinity of structure A5910 on U.S. Highway 24 at Waverly, Missouri, on April 25, 2013, and July 21, 2011.

13. Map showing bathymetry and vertically averaged velocities of the Missouri River channel in the vicinity of structure A5910 on U.S. Highway 24 at Waverly, Missouri....25

14. Map showing bathymetric survey of the Missouri River channel in the vicinity of structure K0999 on State Highway 41 at Miami, Missouri.

15. Profile showing key features, substructural and superstructural details, and surveyed channel bed of structure K0999 on State Highway 41 over the Missouri River at Miami, Missouri.

16. Map showing difference between bathymetric surfaces created from surveys of the Missouri River channel in the vicinity of structure K0999 on State Highway 41 at Miami, Missouri, on April 25, 2013, and July 21, 2011.

17. Map showing bathymetry and vertically averaged velocities of the Missouri River channel in the vicinity of structure K0999 on State Highway 41 at Miami, Missouri ......30

18. Map showing bathymetric survey of the Missouri River channel in the vicinity of structure G0069 on State Highway 240 at Glasgow, Missouri.

19. Profile showing key features, substructural and superstructural details, and surveyed channel bed of structure G0069 on State Highway 240 over the Missouri River at Glasgow, Missouri

20. Visualizations of the channel bed and right (west) side of main channel pier 2 of structure G0069 on State Highway 240 and the upstream railroad bridge pier over the Missouri River at Glasgow, Missouri, as a point cloud and shaded triangulated irregular network (TIN)

21. Map showing difference between bathymetric surfaces created from surveys of the Missouri River channel in the vicinity of structure G0069 on State Highway 240 at Glasgow, Missouri, on April 26, 2013, and July 22, 2011

22. Map showing bathymetry and vertically averaged velocities of the Missouri River channel in the vicinity of structure G0069 on State Highway 240 at Glasgow, Missouri..... 
23. Map showing bathymetric survey of the Missouri River channel in the vicinity of structure A4574 on State Highway 5 at Boonville, Missouri .

24. Profile showing key features, substructural and superstructural details, and surveyed channel bed of structure A4574 on State Highway 5 over the Missouri River at Boonville, Missouri .

25. Map showing difference between bathymetric surfaces created from surveys of the Missouri River channel in the vicinity of structure A4574 on State Highway 5 at Boonville, Missouri, on April 29, 2013, and July 25, 2011

26. Map showing bathymetry and vertically averaged velocities of the Missouri River channel in the vicinity of structure A4574 on State Highway 5 at Boonville, Missouri

27. Map showing bathymetric survey of the Missouri River channel in the vicinity of structure L0962 on Interstate 70 near Rocheport, Missouri.

28. Profile showing key features, substructural and superstructural details, and surveyed channel bed of structure L0962 on Interstate 70 over the Missouri River near Rocheport, Missouri

29. Map showing difference between bathymetric surfaces created from surveys of the Missouri River channel in the vicinity of structure L0962 on Interstate 70 near Rocheport, Missouri, on April 29, 2013, and July 26, 2011.

30. Map showing bathymetry and vertically averaged velocities of the Missouri River channel in the vicinity of structure L0962 on Interstate 70 near Rocheport, Missouri

31. Map showing bathymetric survey of the Missouri River channel in the vicinity of structures L0550 and A4497 on U.S. Highway 54 at Jefferson City, Missouri

32. Profile showing key features, substructural and superstructural details, and surveyed channel bed of structure L0550 on U.S. Highway 54 over the Missouri River at Jefferson City, Missouri...

33. Profile showing key features, substructural and superstructural details, and surveyed channel bed of structure A4497 on U.S. Highway 54 over the Missouri River at Jefferson City, Missouri...

34. Shaded triangulated irregular network visualization of the channel bed and right (southwest) side of main channel piers of structures L0550 and A4497 on U.S. Highway 54 over the Missouri River at Jefferson City, Missouri.

35. Graph showing water-surface and channel-bed elevations as recorded at the real-time scour monitors on the upstream nose of the upstream and downstream main channel piers of structures L0550 and A4497 on U.S. Highway 54 crossing the Missouri River at Jefferson City, Missouri, for the period November 1, 2010, to June 30, 2013.

36. Maps showing difference between bathymetric surfaces created from surveys of the Missouri River channel in the vicinity of structures L0550 and A4497 on U.S. Highway 54 at Jefferson City, Missouri, on April 20, 2013, and July 27, 2011, March 1, 2011, and January 26, 2010.

37. Map showing bathymetry and vertically averaged velocities of the Missouri River channel in the vicinity of structures L0550 and A4497 on U.S. Highway 54 at Jefferson City, Missouri...

38. Map showing bathymetric survey of the Missouri River channel in the vicinity of structure A6288 on State Highway 19 at Hermann, Missouri.

39. Profile showing key features, substructural and superstructural details, and surveyed channel bed of structure A6288 on State Highway 19 over the Missouri River at Hermann, Missouri 
40. Map showing difference between bathymetric surfaces created from surveys of the Missouri River channel in the vicinity of structure A6288 on State Highway 19 at Hermann, Missouri, on May 2, 2013, and July 28, 2011

41. Map showing bathymetry and vertically averaged velocities of the Missouri River channel in the vicinity of structure A6288 on State Highway 19 at

Hermann, Missouri...

42. Map showing bathymetric survey of the Missouri River channel in the vicinity of structure K0969 on State Highway 47 at Washington, Missouri.

43. Profile showing key features, substructural and superstructural details, and surveyed channel bed of structure K0969 on State Highway 47 over the Missouri River at Washington, Missouri.

44. Map showing difference between bathymetric surfaces created from surveys of the Missouri River channel in the vicinity of structure K0969 on State Highway 47 at Washington, Missouri, on April 22, 2013, and July 27, 2011

45. Map showing bathymetry and vertically averaged velocities of the Missouri River channel in the vicinity of structure K0969 on State Highway 47 at Washington, Missouri.

\section{Appendix Figures}

1-1. Shaded triangulated irregular network visualization of the channel bed and left (northwest) side, and right (southeast) side of main channel pier 21 of structure A5664 on State Highway 13 over the Missouri River at Lexington, Missouri

1-2. Shaded triangulated irregular network visualization of the channel bed and left (north) side, and right (south) side of main channel pier 11 of structure A5910 on U.S. Highway 24 over the Missouri River at Waverly, Missouri.

1-3. Shaded triangulated irregular network visualization of the channel bed and left (northwest) side, and right (southeast) side of main channel pier 5 of structure K0999 on State Highway 41 over the Missouri River at Miami, Missouri

1-4. Shaded triangulated irregular network visualization of the channel bed and left (east) side, and right (west) side of main channel pier 2; left (east) side, and right (west) side of main channel pier 3; and left (east) side of main channel pier 4 of structure G0069 on State Highway 240 over the Missouri River at Glasgow, Missouri.

1-5. Shaded triangulated irregular network visualization of the channel bed and right (south) side of main channel pier 8; left (north) side, and right (south) side of main channel pier 7; and, left (north) side, and right (south) side of main channel pier 6 of structure A4574 on State Highway 5 over the Missouri River at Boonville, Missouri.

1-6. Shaded triangulated irregular network visualization of the channel bed and left (northeast) side, and right (southwest) side of main channel pier 14 of structure L0962 on Interstate 70 over the Missouri River near Rocheport, Missouri

1-7. Shaded triangulated irregular network visualization of the channel bed and left (northeast) side, and right (southwest) side of main channel pier 4 of structures L0550 and A4497 on U.S. Highway 54 over the Missouri River at Jefferson City, Missouri. 
1-8. Shaded triangulated irregular network visualization of the channel bed and left (northwest) side, and right (southeast) side of main channel pier 5; and, left (northwest) side, and right (southeast) side of main channel pier 4 of structure A6288 on State Highway 19 over the Missouri River at Hermann, Missouri ..

1-9. Shaded triangulated irregular network visualization of the channel bed and left (northeast) side, and right (southwest) side of main channel pier 6; left (northeast) side, and right (southwest) side of main channel pier 5; and left (northeast) side, and F, right (southwest) side of main channel pier 4 of structure K0969 on State Highway 47 over the Missouri River at Washington, Missouri.

\section{Tables}

1. Highway bridges crossing the Missouri River, in and into Missouri, in downstream order.

2. Bridge and survey information, and selected channel-bed elevations from surveys on the Missouri River between Kansas City and St. Louis, Missouri, from April 22 through May 2, 2013

3. Results of a beam angle check from two check lines over a reference surface at Indian Lake near Cuba, Missouri, on September 4, 2012.

4. Patch test results from surveying on the Missouri River between Kansas City and St. Louis, Missouri

5. Total propagated uncertainty results for bathymetric data at a 1.64-feet grid spacing from surveys on the Missouri River between Kansas City and St. Louis, Missouri, from April 22 through May 2, 2013.

6. Results near piers from surveys on the Missouri River between Kansas City and St. Louis from April 22 through May 2, 2013

7. Summary information and bathymetric surface difference statistics from surveys on the Missouri River between Kansas City and St. Louis from April 22 through May 2, 2013, and previous surveys

\section{Conversion Factors}

Inch/Pound to SI

\begin{tabular}{lcl}
\hline \multicolumn{1}{c}{ Multiply } & By & \multicolumn{1}{c}{ To obtain } \\
\hline & Length & \\
\hline foot $(\mathrm{ft})$ & 0.3048 & meter $(\mathrm{m})$ \\
mile $(\mathrm{mi})$ & 1.609 & kilometer $(\mathrm{km})$ \\
\hline & Flow rate & \\
\hline foot per second $(\mathrm{ft} / \mathrm{s})$ & 0.3048 & meter per second $(\mathrm{m} / \mathrm{s})$ \\
cubic foot per second $\left(\mathrm{ft}^{3} / \mathrm{s}\right)$ & 0.02832 & cubic meter per second $\left(\mathrm{m}^{3} / \mathrm{s}\right)$ \\
\hline
\end{tabular}

Vertical coordinate information is referenced to the North American Vertical Datum of 1988 (NAVD 88).

Horizontal coordinate information is referenced to the North American Datum of 1983 (NAD 83).

In this report, the words "left" and "right" generally refer to directions that would be reported by an observer facing downstream. 


\section{Abbreviations}

ADCP acoustic Doppler current profiler

CUBE combined uncertainty bathymetric estimator

GIS geographic information system

GNSS global navigation satellite system

IMU inertial motion unit

MBES multibeam echosounder (the sonar system)

MBMS multibeam echosounder mapping system (the sonar, navigation, and data acquisition system)

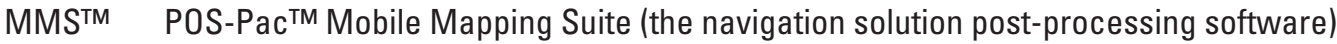

MoDOT Missouri Department of Transportation

NAVD 88 North American Vertical Datum of 1988

POS MV Position Orientation Solution for Marine Vessels (the navigation system)

RM river mile

RTK real-time kinematic (a type of differential correction for navigation with GNSS)

SBET standard best estimate of travel (a post-processed navigation solution)

TIN triangulated irregular network

USGS U.S. Geological Survey

VRS virtual real-time station network (a cellular network maintained by MoDOT that provides differential corrections for navigation with GNSS) 


\title{
Bathymetric and Velocimetric Surveys at Highway Bridges Crossing the Missouri River between Kansas City and St. Louis, Missouri, April-May 2013
}

\author{
By Richard J. Huizinga
}

\section{Abstract}

Bathymetric and velocimetric data were collected by the U.S. Geological Survey, in cooperation with the Missouri Department of Transportation, in the vicinity of 10 bridges at 9 highway crossings of the Missouri River between Lexington and Washington, Missouri, from April 22 through May 2, 2013. A multibeam echosounder mapping system was used to obtain channel-bed elevations for river reaches ranging from 1,640 to 1,840 feet longitudinally and extending laterally across the active channel between banks and spur dikes in the Missouri River during low- to moderate-flow conditions. These bathymetric surveys indicate the channel conditions at the time of the surveys and provide characteristics of scour holes that may be useful in the development of predictive guidelines or equations for scour holes. These data also may be useful to the Missouri Department of Transportation to assess the bridges for stability and integrity issues with respect to bridge scour during floods.

Bathymetric data were collected around every pier that was in water, except those at the edge of water or in very shallow water (less than about 6 feet). Scour holes were present at most piers for which bathymetry could be obtained, except at piers on channel banks, near or embedded in lateral or longitudinal spur dikes, and on exposed bedrock outcrops. Scour holes observed at the surveyed bridges were examined with respect to depth and shape. Although exposure of parts of foundational support elements was observed at several piers, at most sites the exposure likely can be considered minimal compared to the overall substructure that remains buried in channel-bed material; however, there were several notable exceptions where the bed material thickness between the bottom of the scour hole and bedrock was less than 6 feet. Such substantial exposure of usually buried substructural elements may warrant special observation in future flood events.

Previous bathymetric surveys had been done at all of the sites in this study during the flood of 2011. Comparisons between bathymetric surfaces from the previous surveys and those of this study generally indicate a consistent increase in the elevation of the bed and decrease in the size of scour holes at these sites, both likely caused by a substantial decrease in discharge and water-surface elevation compared to the 2011 surveys at most sites. However, multiple surveys at one of the sites indicate that the flow condition is not the sole variable in the determination of the size of scour holes at sites with a dual bridge configuration. Furthermore, another site had a smaller and shallower scour hole even though the discharge in this study was slightly greater than in 2011. Pier size, nose shape, and alignment to flow also had a substantial effect on the size of the scour hole observed.

\section{Introduction}

Scour in alluvial channels is the removal of channel bed and bank material by flowing water, and is the leading cause of bridge failures in the United States (Richardson and Davis, 2001). Scour at a bridge site is the result of short- and longterm geomorphic processes and the local effects caused by elements of the structure in or adjacent to the waterway (Richardson and Davis, 2001; Huizinga and Rydlund, 2004). Because the effects of scour can be severe and dangerous, bridges and other structures over waterways are routinely assessed and inspected. Scour processes can be exacerbated during highflow conditions.

The Missouri Department of Transportation (MoDOT) is responsible for most of the transportation infrastructure in the State. A part of this responsibility is fulfilled through periodic inspections of highway structures, including bridges that span waterways. At most of these structures, all or most of the structure can be fully inspected from land or from personnel lift trucks deployed from the roadway of the structure; however, for structures over primary waterways, such as the Missouri River, inspection of the part of the bridge that is underwater requires a different approach.

The U.S. Geological Survey (USGS), in cooperation with MoDOT, began assessing scour at waterway crossings throughout the state in 1991 (Huizinga and Rydlund, 2004). In 2007, the USGS, in cooperation with MoDOT, began determining channel bathymetry and monitoring bridges for scour 
using single-beam echosounders and a multibeam echosounder mapping system (Rydlund, 2009; Huizinga, 2010, 2011, 2013; Huizinga and others, 2010). In particular, the multibeam mapping system has proven to be a useful tool not only in determining channel bathymetry, but also in providing a medium- to high-resolution representation of bridge structural elements below the water line. In 2010 the USGS, in cooperation with MoDOT, began collecting bathymetric data at various highway bridges across primary waterways in Missouri. In March 2010, 9 highway bridges at 7 crossings over the Missouri River in Kansas City, Mo., were assessed using the multibeam mapping system (Huizinga, 2010), and in October 2010, 12 highway bridges at 7 crossings over the Missouri and Mississippi Rivers near St. Louis, Mo., were assessed (Huizinga, 2011). During high-flow conditions in June-August 2011, many of the highway bridges and several of the railroad bridges along the entirety of the Missouri River downstream from Montana were assessed (Huizinga, 2012; Densmore and others, 2013; Dietsch and others, 2014), including the 37 highway bridges that span the Missouri River in and into Missouri.

This study encompasses the more routine surveys at the highway bridges across the Missouri River in the middle of Missouri (fig. 1) - those referred to in Huizinga (2012) as being "between Kansas City and St. Louis"- that entails 10 bridges at 9 crossings (table 1). One railroad bridge also was surveyed as part of this study because of its proximity to the highway bridge at Glasgow, Mo., but will be discussed only incidentally in this report.

\section{Purpose and Scope}

The purpose of this report is to document the results of bathymetric and velocimetric surveys of the Missouri River channel in the vicinity of 10 highway bridges at 9 crossings of the river in the middle part of Missouri using a multibeam echosounder mapping system (MBMS) and an acoustic Doppler current profiler (ADCP; table 1). Equipment and methods used and results obtained are described. The results obtained from the bathymetric and velocimetric surveys of the channel indicate the channel-bed conditions at the time of the surveys and provide characteristics of scour holes that may be useful in developing predictive guidelines or equations for scour holes. These data also may be used by MoDOT to assess the bridges for stability and integrity issues with respect to bridge scour. Comparison of results to prior surveys (Huizinga, 2012) also are provided.

\section{Description of Study Area}

The overall study area for this report is 250 miles (mi) of the Lower Missouri River in the middle part of Missouri, between Kansas City and St. Louis, Mo. (fig. 1). From Kansas City, the Missouri River flows generally eastward to the greater St. Louis area, joining the Mississippi River north of downtown St. Louis, Mo. (fig. 1). All of the highway crossings on the Missouri River between Lexington and Washington, Mo., were examined as part of this study. The site numbering sequence used in Huizinga (2012) will be used in this report for consistency and comparability.

\section{Description of Flow Conditions}

The Missouri River was transitioning from moderateto low-flow conditions when the sites were surveyed from April 22 through May 2, 2013 (fig. 2). A flood pulse was observed at USGS streamflow-gaging stations (hereinafter referred to as "streamgages") on the Missouri River upstream from the study area beginning on April 17 (fig. 2), and forecasted weather conditions indicated that the pulse might last several weeks. It is possible to "chase" many flood pulses as they move downstream, such that sites surveyed in succession moving downstream can be caught near the peak discharge at the site; however, federal budget constraints, difficulties in mobilizing, and bouts of adverse weather prevented an effective application of this technique for these surveys.

The downstream-most site, structure K0969 on State Highway 47 at Washington, Mo. (site 22, fig. 1), was surveyed first on April 22. The discharge on the Missouri was approximately 232,000 cubic feet per second $\left(\mathrm{ft}^{3} / \mathrm{s}\right)$, as obtained from the rating curve for the streamgage at Hermann, Mo. (station 06934500) (figs. 1 and 2; U.S. Geological Survey, 2014), but was approximately $245,000 \mathrm{ft}^{3} / \mathrm{s}$ as measured at the site (table 2). This discharge range has a daily exceedance between 24 to 27 percent (U.S. Geological Survey, 2003), and is near the 50-percent annual exceedance probability (2-year recurrence interval) flood discharge of $250,000 \mathrm{ft}^{3} / \mathrm{s}$ at this site (U.S. Army Corps of Engineers, 2004a, plate E-20).

By contrast, the last site, structure A6288 on State Highway 19 at Hermann, Mo. (site 21, fig. 1), was surveyed on May 2, and discharge on the Missouri was approximately $105,000 \mathrm{ft}^{3} / \mathrm{s}$ as obtained from the rating curve for the streamgage at Hermann, Mo. (fig. 2), and approximately $108,000 \mathrm{ft}^{3} / \mathrm{s}$ as measured during the survey (table 2). This discharge range has a daily exceedance between 67 to 69 percent (U.S. Geological Survey, 2003), and is near the 95-percent annual exceedance probability (1.05-year recurrence interval) flood discharge of 111,000 ft $\mathrm{ft}^{3} / \mathrm{s}$ at this site (U.S. Army Corps of Engineers, 2004a, Plate E-20).

Similarly, the upstream-most sites [structure A5664 on State Highway 13 at Lexington, Mo. (site 14), structure A5910 on U.S. Highway 24 at Waverly, Mo. (site 15), and structure K0999 on State Route 41 at Miami, Mo. (site 16)] were surveyed when discharge on the Missouri ranged from 41,100 to $44,600 \mathrm{ft}^{3} / \mathrm{s}$ as measured during the survey (table 2). This discharge range has a daily exceedance greater than 95 percent (U.S. Geological Survey, 2003), and is well below the 99-percent annual exceedance probability (1.01-year recurrence interval) flood discharge of $66,100 \mathrm{ft}^{3} / \mathrm{s}$ at these sites (U.S. Army Corps of Engineers, 2004a, Plate E-20). 


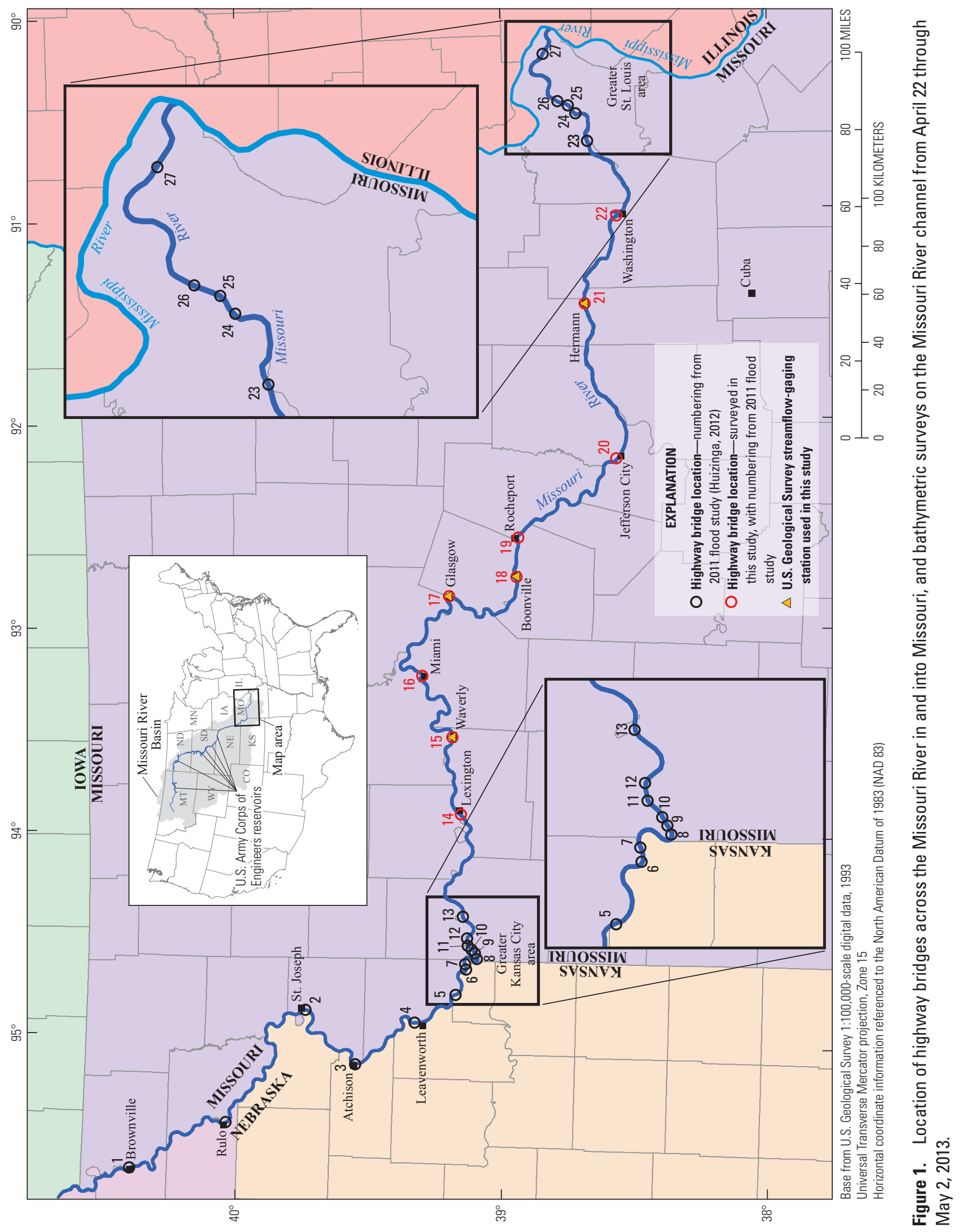




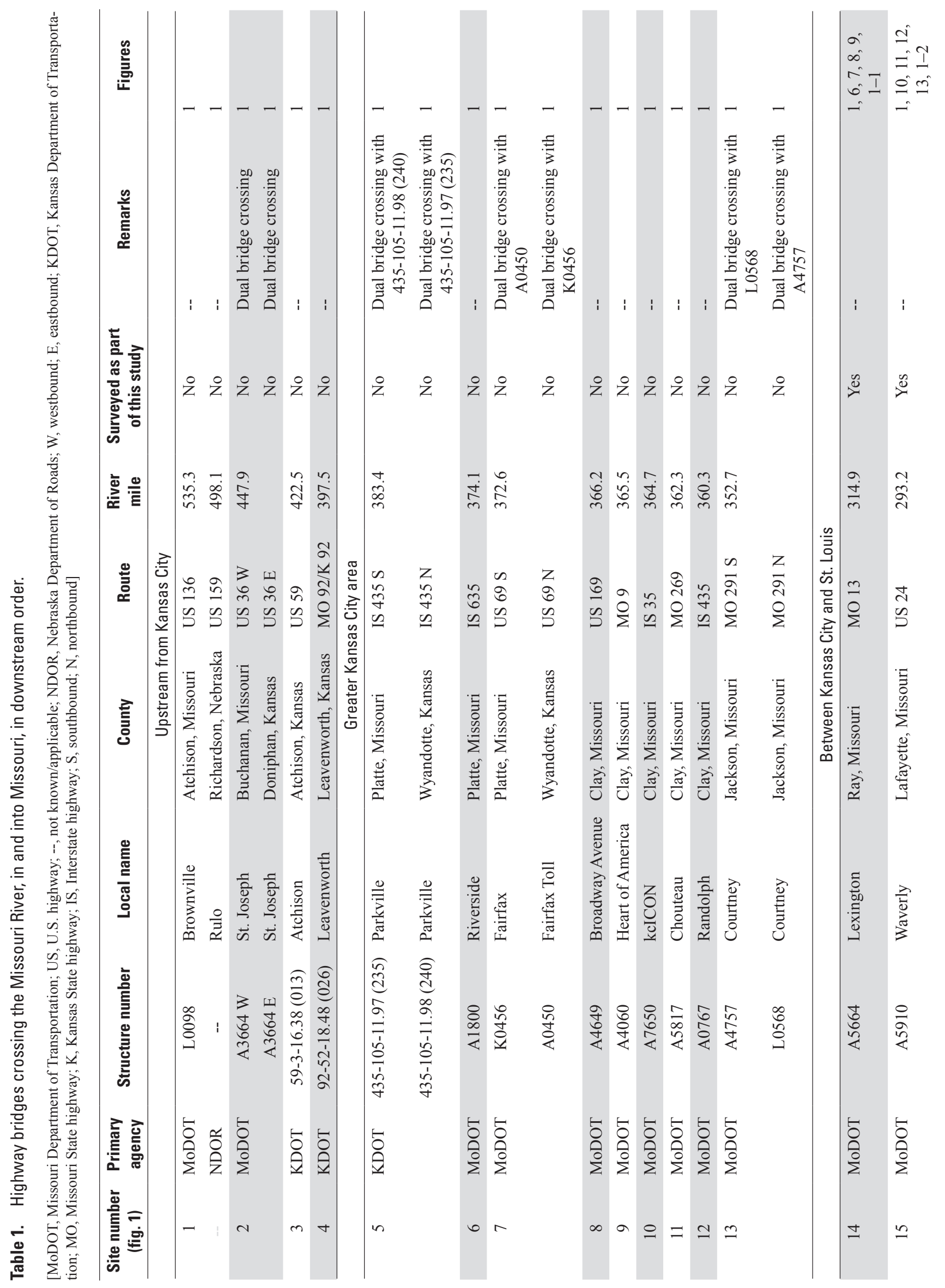




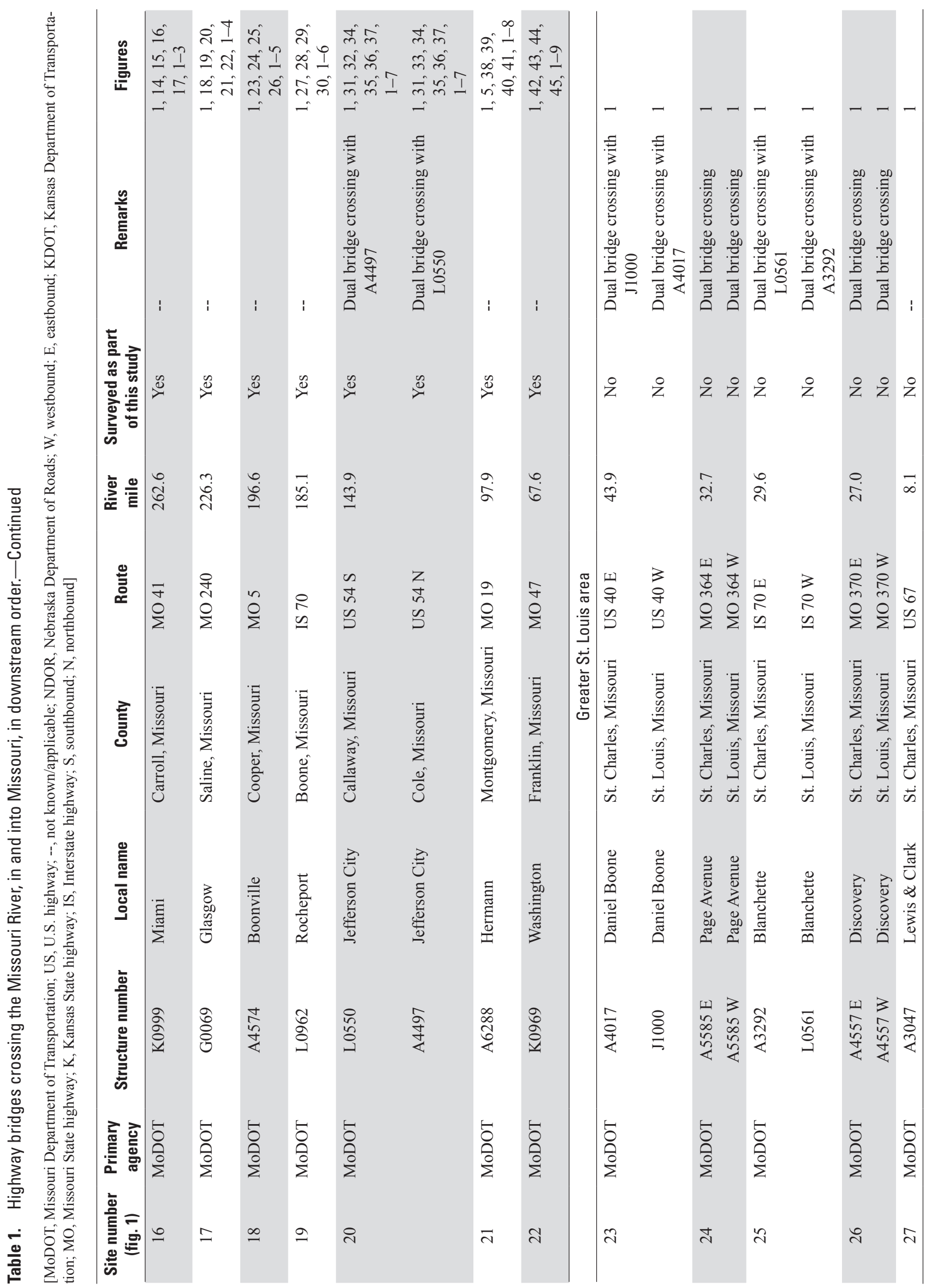




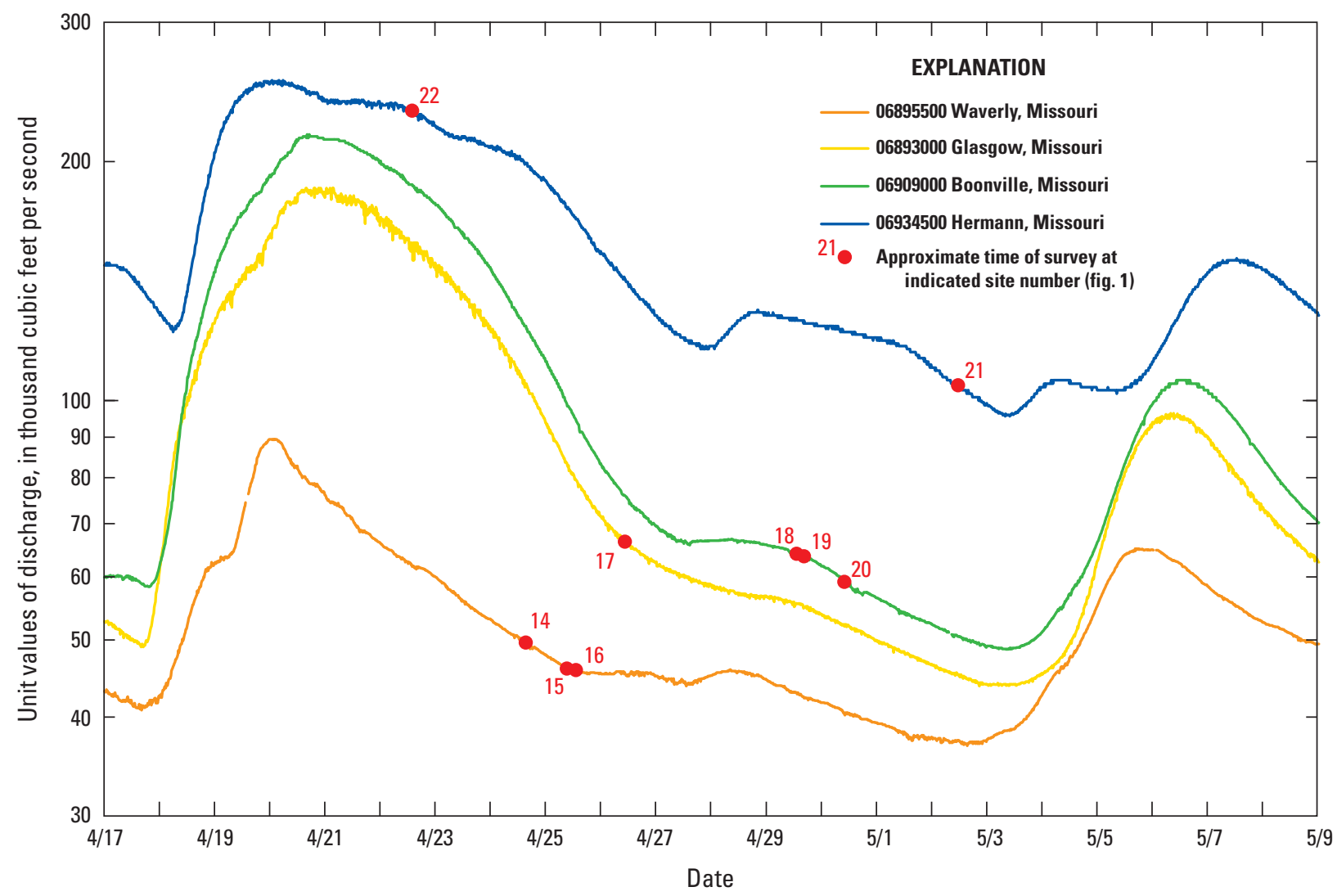

Figure 2. Unit values of discharge (15-minute interval) at selected streamflow-gaging stations in the study area on the Missouri River between Kansas City and St. Louis, Missouri, from April 17 through May 9, 2013 (U.S Geological Survey, 2014).

With the exception of the first site surveyed, all of the sites were surveyed well after the peak of the flood pulse at the respective site, per the hydrographs from selected streamgages in the study area (fig. 2).

\section{Description of Equipment}

The bathymetry of the Missouri River at each of the bridges was determined using a high-resolution MBMS. The various components of the MBMS used for this study are described in reports about studies on the Missouri and Mississippi Rivers in Missouri (Huizinga, 2010, 2011, 2012, 2013; Huizinga and others, 2010) and on the Missouri and Yellowstone Rivers in North Dakota (Densmore and others, 2013). The survey methods used to obtain the data were similar to these previous studies, as were the measures used to ensure data quality. A brief description of the equipment follows; a complete description of the various system components and methods used in this study is available in the previous reports by Huizinga (2010), Huizinga and others (2010), and Densmore and others (2013).
An MBMS is an integration of several individual components: the multibeam echosounder (MBES), a navigation and motion-sensing system, and a data-collection and -processing computer. The MBES that was used is the Teledyne RESON SeaBat ${ }^{\mathbb{B}}$ 7125-SV2 (fig. 3), operated at a frequency of 400 kilohertz $(\mathrm{kHz})$. The SeaBat ${ }^{\circledR} 7125$-SV2 is an updated version of the SeaBat ${ }^{\mathbb{B}} 7125$ used in the earliest previous studies (Huizinga, 2010, 2011; Huizinga and others, 2010) with similar features and functions, but having a more streamlined sonar head, and stiffer, more compact head tilt bracket (fig. 3). The navigation and motion-sensing system that was used is the Applanix Position Orientation Solution for Marine Vessels (POS MVTM) WaveMaster system (hereinafter referred to as "the POS"). The navigation system locates the MBES in threedimensional space, and the motion-sensing system measures the heave, pitch, roll, and heading of the vessel (and, thereby, the MBES) to accurately position the data received by the MBES. A cellular network link to the Virtual Real-time Station (VRS) network (established and maintained by MoDOT, available through registration at http://gpsweb.modot.mo.gov/) was used to provide the real-time kinematic (RTK) differential corrections to the POS for the navigation and tide solution during the survey. 
Table 2. Bridge and survey information, and selected channel-bed elevations from surveys on the Missouri River between Kansas City and St. Louis, Missouri, from April 22 through May 2, 2013.

[MoDOT, Missouri Department of Transportation; ADCP, acoustic Doppler current profiler; $\mathrm{ft} / \mathrm{s}$, cubic feet per second; ft, feet; MO, State highway; US, U.S. highway; IS, Interstate highway; all elevations are in feet above the North American Vertical Datum of 1988]

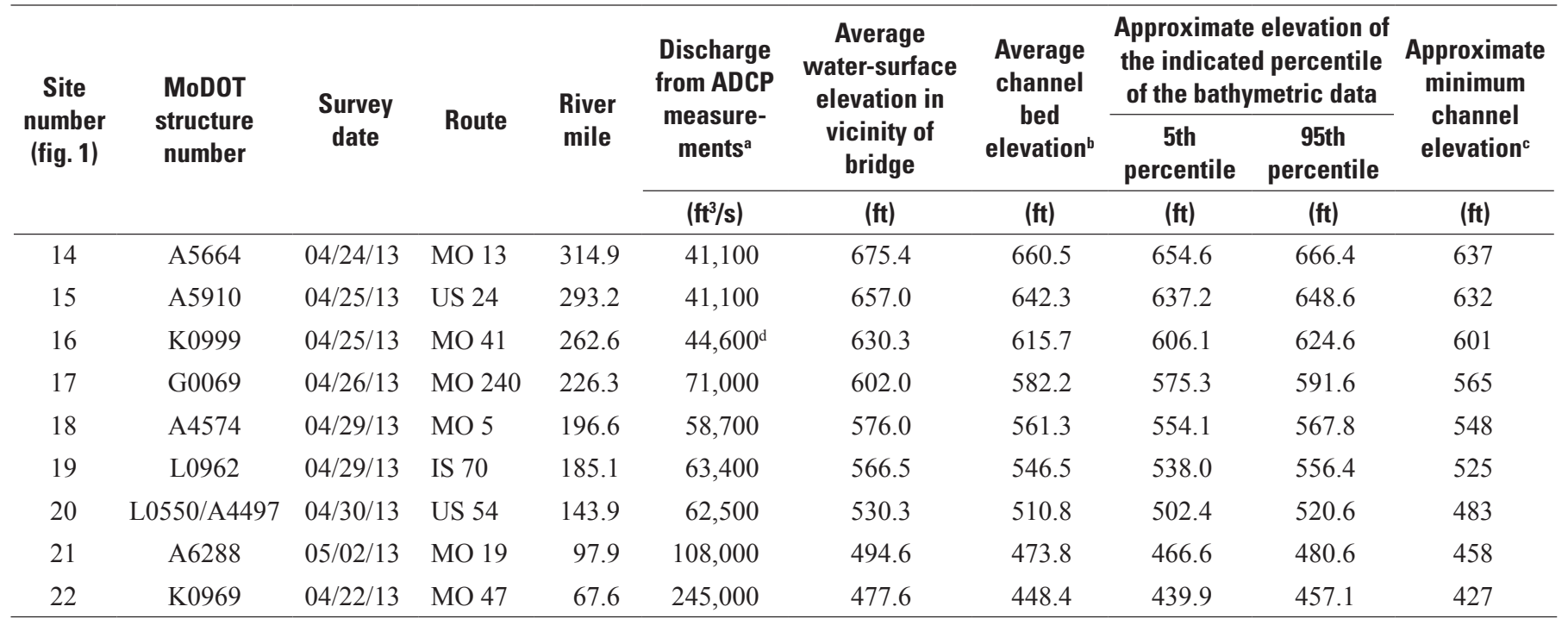

aThe average discharge obtained while making the various velocity transects.

${ }^{\mathrm{b}}$ The statistical average of the surveyed channel-bed elevations.

'The minimum channel-bed elevation, not necessarily in any scour holes near the bridge.

dThis site had a large area of estimated flow on the left side of the channel that might have skewed the discharge results higher than the discharge at the upstream streamflow-gaging station at Waverly (fig. 2).
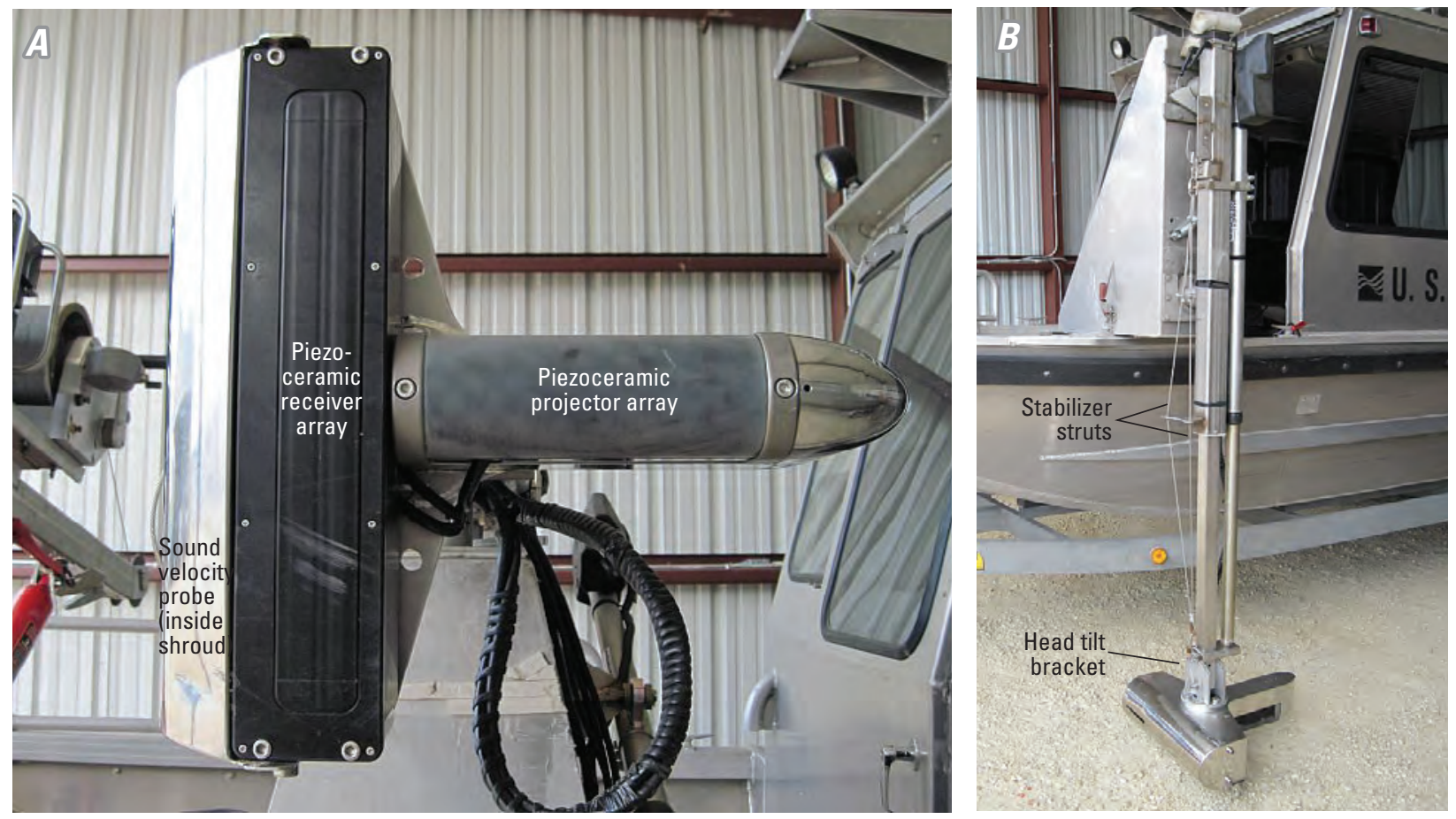

Figure 3. The Teledyne RESON SeaBat ${ }^{\circledR} 7125$-SV2 multibeam echosounder, as viewed, $A$, from the bottom, and $B$, mounted on the port side of the U.S. Geological Survey boat. 
The bridge structure blocked a part of or the whole signal from the Global Navigation Satellite System (GNSS) constellation of satellites when the survey vessel was near or under a bridge. The blocked signal resulted in a GNSS outage that had the potential to degrade the positional accuracy of the vessel until such time as an RTK-fixed navigation solution was re-acquired; however, as in nearly all the previous studies of bathymetry at bridge sites in Missouri (Huizinga, 2010, 2011, 2012, 2013), the navigation information from the survey was post-processed using the POS-Pac ${ }^{\mathrm{TM}}$ Mobile Mapping Suite $\left(\mathrm{MMS}^{\mathrm{TM}}\right)$ software (Applanix Corporation, 2009), which provided tools to identify and compensate for sensor and environmental errors, and computed an optimally blended navigation solution from the GNSS and inertial motion unit (IMU) raw data. The blended navigation solution (called a "standard best-estimate of travel" or "SBET" file), generated by post-processing the navigation data, was applied to the whole survey at a given bridge to minimize the effects of the GNSS outages while surveying under the bridges.

The data from the MBES, and navigation and motionsensing components, were processed and integrated into a cohesive dataset for cleanup and visualization. A computer onboard the survey boat ran the HYPACK ${ }^{\circledR} / \mathrm{HYSWEEP}^{\circledR}$ data acquisition software (HYPACK, Inc., 2011) that was used to prepare for the bathymetric surveys and collect the survey data. After completing the surveys, the acquired depth data were further processed to remove data spikes and other spurious points in the multibeam swath trace, georeferenced using the navigation and position solution data from the SBET file from POS-Pac ${ }^{\mathrm{TM}} \mathrm{MMS}^{\mathrm{TM}}$, and visualized in $\mathrm{HYPACK}^{\circledR} /$ HYSWEEP ${ }^{\circledR}$ as a triangulated irregular network (TIN) surface or a point cloud. The georeferenced data were output to a comma-delimited file, either having no data reduction or filtered and reduced to a $1.64-$ foot $^{1}(\mathrm{ft})$ data resolution. These comma-delimited data were compiled into a geographic information system (GIS) database for each site using the ArcGIS package (Environmental Systems Research Institute, 2013).

Information about the velocity of the river at various points throughout each study reach were obtained by means of an ADCP, as was done in the studies by Huizinga and others (2010), and refined in later studies by Huizinga $(2012,2013)$. A Sontek RiverSurveyor ${ }^{\circledR}$ M9 ADCP operating at $1,000 \mathrm{kHz}$ was used to obtain velocities at depth increments, or "bins," ranging from 0.07 to $3.28 \mathrm{ft}$ (varying, depending on total depth) throughout the water column. The RiverSurveyor ${ }^{\circledR}$ M9 operates in depths from 1 to $131 \mathrm{ft}$ and determines the velocity of the water by measuring the Doppler shift of an acoustic signal reflected from various particles suspended in the water (Mueller and Wagner, 2009). By measuring the Doppler shift in four different beam directions, the velocity of the water in each bin can be determined in three dimensions.

\footnotetext{
${ }^{1}$ Data were collected, processed, and output in SI units, and converted to foot-pound units for presentation in the report at the request and for the convenience of the cooperator. A distance of 1.64 feet corresponds to 0.5 meter.
}

\section{Basic Description of Methods}

The methods used to acquire and assure the collection of quality data were the same as those used in previous studies using the MBES (Huizinga, 2010, 2011, 2012, 2013; Huizinga and others, 2010), and the reader is referred to those reports for the details of the methods used. A brief summary of - and differences from - these methods are highlighted below.

\section{Surveying Methods}

The size of the surveyed area at each site was dictated somewhat by the flow conditions. Because of the low to moderate flow conditions on the Missouri River during the survey dates (April 22-May 2, 2013), many of the lateral and longitudinal spur dikes were not submerged and made it difficult or impossible to survey from bank to bank as had been done in the previous study during the 2011 flood (Huizinga, 2012). Generally, the surveyed areas extended across the active channel between longitudinal spur dikes or banks on one side of the channel to the shallows in the vicinity of the spur dikes on the opposite side, as had been done in the previous study in St. Louis, Mo., during 2010 (Huizinga, 2011). The surveyed areas were approximately $1,640 \mathrm{ft}$ long in the direction of flow, positioned so that the surveyed highway bridges were approximately one-third to one-half of the total length from the upstream boundary, and used approximately the same upstream and downstream boundaries as were used in the 2011 flood study (Huizinga, 2012). The upstream and downstream boundaries of the surveyed areas were assumed to be beyond the hydraulic effect of the bridge structures.

As in previous studies, bathymetric data were obtained along longitudinal transect lines, and each survey was designed so that there was overlap of the survey swaths to attempt to ensure complete coverage of the channel bed and minimize sonic "shadows." Substantial overlap was achieved for many of the surveyed swaths, except in shallow areas near the channel banks or spur dikes and near debris rafts. To minimize data acquisition times in the shallows, data gaps were left between the swaths. The presence of debris rafts made surveying difficult in some areas. Areas near the bridge piers and along the banks also were surveyed in an upstream direction with the MBES head tilted at either 30 degrees to port or starboard to increase the acquisition of bathymetric data in the shallow areas, and higher on the banks and the sides of the piers. To limit damage to the MBES head, most of the very shallow areas (less than about $6 \mathrm{ft}$ of water depth) were not surveyed.

After completion of the bathymetric survey with the MBMS at a given site, the velocity data were obtained with the ADCP on seven lateral transects across the channel within the study area. The distance between the velocity transect lines generally was about $260 \mathrm{ft}$. Three transects were upstream and four transects were downstream from the bridge in question. 
Each transect line was traversed in each direction across the river. The reported velocity values are the average from the two traverses.

\section{Survey Quality-Assurance/Quality-Control Measures}

A quality-assurance plan has been established for discharge measurements using ADCPs that includes several instrument diagnostic checks and calibrations. These standard operating procedures were followed when acquiring the velocity profile data for these surveys. For a detailed discussion of these procedures, see Oberg and others (2005).

For the MBMS, the principal quality-assurance measures were assessed in real time during the survey. The MBMS operator continuously assessed the quality of the collected data during the survey by making visual observations of across-track swaths (such as convex, concave, or skewed bed returns in flat, smooth bottoms), noting data quality flags and alarms from the MBES and the POS, and noting comparisons between adjacent overlapping swaths. In addition to the realtime quality-assurance assessments during the survey, beam angle checks and a suite of patch tests were executed to ensure quality data were acquired from the MBMS.

\section{Beam Angle Check}

A beam angle check is used to determine the accuracy of the depth readings obtained by the outer beams [greater than 25 degrees from nadir (vertical)] of the MBES (U.S. Army Corps of Engineers, 2004b), which may change with time as a result of inaccurate sound velocities, physical configuration changes, and overall depth being surveyed. The HYPACK ${ }^{\circledR /}$ HYSWEEP $^{\circledR}$ software has a utility that develops a statistical assessment of the quality of the outer beams compared to a reference surface (HYPACK, Inc., 2011). On September 4, 2012, a reference surface was created for a part of Indian Lake near Cuba, Mo. (fig. 1), and check lines were run across the reference surface. The results of this beam angle check (table 3) were within the recommended performance standards used by the U.S. Army Corps of Engineers for hydrographic surveys for all angles (U.S. Army Corps of Engineers, 2004b), permitting the use of the full sonar swath.

Ideally, the average depth of the reference surface used in the beam angle check would be greater than or equal to the depth in the area being surveyed. Unfortunately, the depth of the Missouri River in each study reach generally was impossible to estimate before each survey because of the dynamic nature of the channel bed and flow conditions. The average depth of the reference surface (about $30 \mathrm{ft}$ ) was greater than the average depth (14.6-29.2 ft) observed in all of the surveys (table 2). As described under the "Surveying Methods" sections earlier in this report, areas having depths greater than the average depths generally had substantial overlap of the surveyed swath with adjacent swaths. Data from the outer beams in these areas were able to be either verified or removed to mitigate any detrimental effects caused by beam angle inaccuracies.

\section{Patch Tests}

Patch tests are a series of dynamic calibration tests that are used to check for subtle variations in the orientation and timing of the MBES with respect to the POS and real-world coordinates. The patch tests are used to determine timing offsets caused by latency between the MBES and the POS, and angular offsets to roll, pitch, and yaw caused by the alignment of the transducer head (fig. 4). These offsets are assumed to be constants for a given survey, barring an event that causes the mount to change, such as striking a submerged object. The offsets determined in the patch test are applied when processing the data collected during a given survey.

In early studies using the MBMS, patch tests were done every day of surveying (Huizinga, 2010, 2011), and offset values remained almost constant, except when notable events occurred that caused the mount to bend (see table 4 in Huizinga, 2010). Given the relative consistency of the offset values observed in the early studies, the additional time required to obtain and process patch test data every day was deemed unwarranted. Therefore, in studies since 2011 (Huizinga, 2012), patch tests have been performed less frequently, and in

Table 3. Results of a beam angle check from two check lines over a reference surface at Indian Lake near Cuba, Missouri, on September 4, 2012.

$[<$, less than; --, no data $]$

\begin{tabular}{ccccc}
\hline $\begin{array}{c}\text { Beam } \\
\text { angle limit } \\
\text { (degrees) }\end{array}$ & $\begin{array}{c}\text { Maximum } \\
\text { outlier } \\
\text { (feet) }\end{array}$ & $\begin{array}{c}\text { Mean } \\
\text { difference } \\
\text { (feet) }\end{array}$ & $\begin{array}{c}\text { Standard } \\
\text { deviation } \\
\text { (feet) }\end{array}$ & $\begin{array}{c}\text { 95-percent } \\
\text { confidence } \\
\text { (feet) }\end{array}$ \\
\hline 20 & 0.82 & 0.13 & 0.16 & 0.30 \\
25 & 0.82 & 0.13 & 0.16 & 0.30 \\
30 & 0.82 & 0.13 & 0.16 & 0.30 \\
35 & 0.82 & 0.10 & 0.16 & 0.30 \\
40 & 0.82 & 0.10 & 0.16 & 0.30 \\
45 & 0.82 & 0.10 & 0.16 & 0.30 \\
50 & 0.82 & 0.10 & 0.16 & 0.30 \\
55 & 0.82 & 0.10 & 0.13 & 0.30 \\
60 & 0.82 & 0.10 & 0.13 & 0.30 \\
65 & 0.82 & 0.13 & 0.16 & 0.30 \\
70 & 0.82 & 0.16 & 0.16 & 0.33 \\
75 & 0.82 & 0.16 & 0.16 & 0.33 \\
\hline \multicolumn{5}{|c|}{ Performance standards ${ }^{\mathrm{a}}$} \\
\hline
\end{tabular}

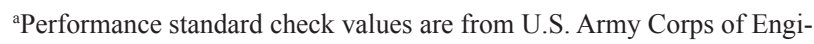
neers (2004b), table 3-1. 


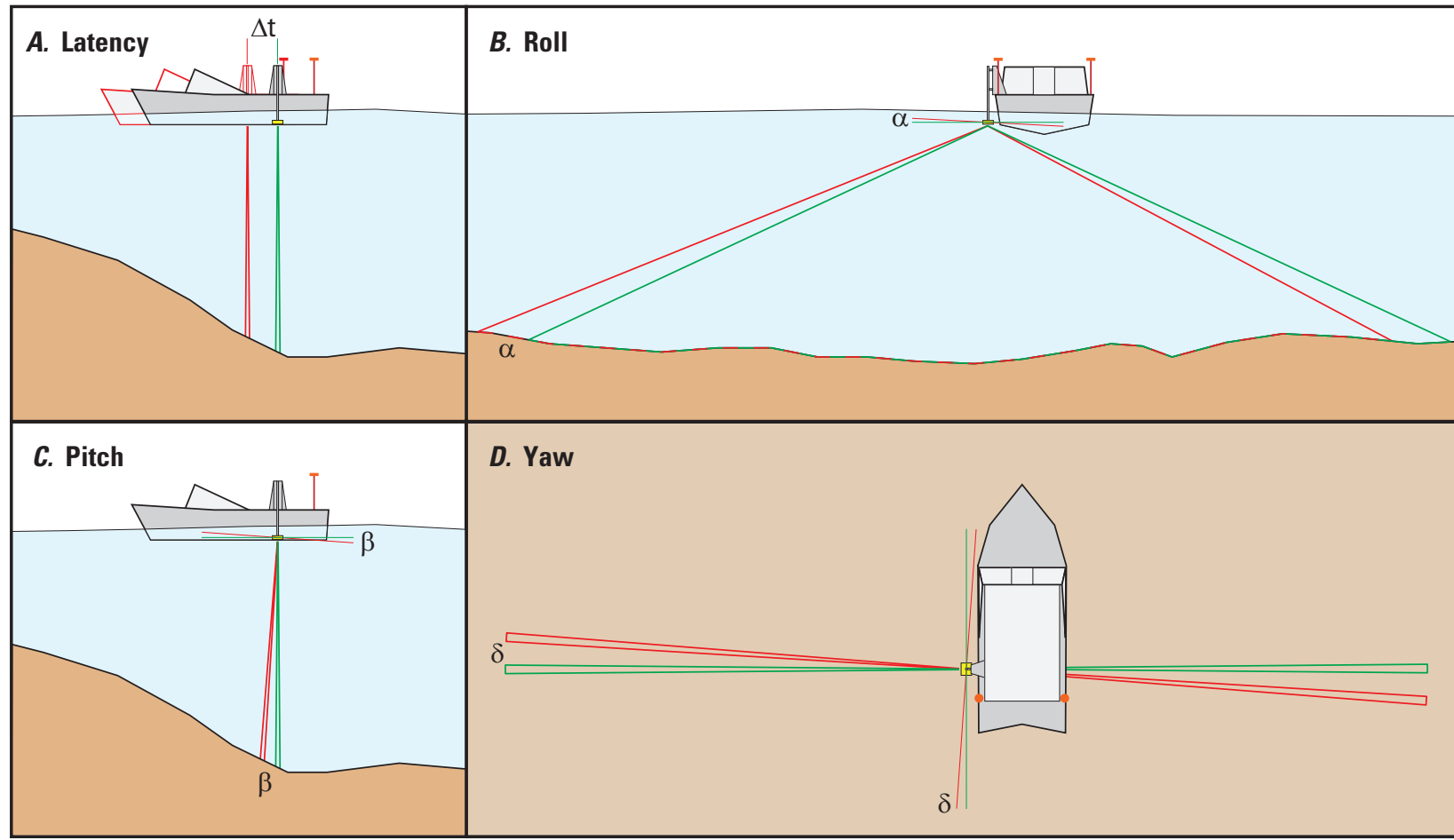

EXPLANATION

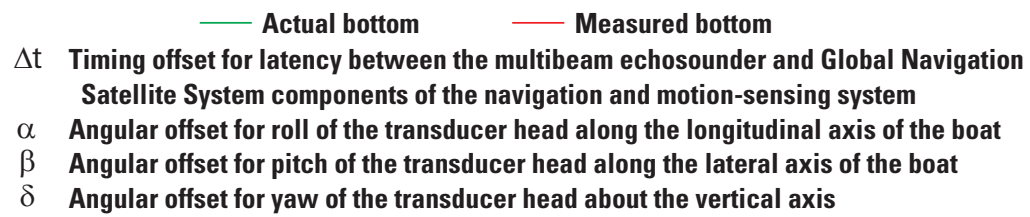

Figure 4. Effects of $A$, timing offset for latency; and angular offsets for $B$, roll; $C$, pitch; and $D$, yaw on data from a multibeam echosounder.

the current study, patch tests were performed twice (table 4): once before the surveys at Indian Lake near Cuba, Mo. (fig. 1), and again after the MBES unit struck a spur dike while surveying at structure A5664 on State Highway 13 at Lexington, Mo. (site 14; fig. 1), on April 24, 2013, causing the mount to bend.

In the bathymetry surveys during the 2011 summer flood, Huizinga (2012) noticed data artifacts indicative of flexure of the pole on which the sonar head is deployed. The flexure resulted in variable pitch of the sonar head based on the speed of the boat and sonar head relative to the water (the pole flexes rearward more when the boat is traveling upstream against the current than when the boat is traveling downstream with the current, resulting in differing pitch values). Stabilizer struts were added to the pole (fig. $3 B$ ), and these effects appear to have been mitigated in later studies (Huizinga, 2013; Richard Huizinga, unpub. data, 2014). Artifacts do not appear in the data from the surveys in the current study.

For this study, there was no measured timing offset (table $4 ; \Delta \mathrm{t}=0$, fig. 4 ), which is consistent with latency test results for this boat and similar equipment configuration used in other surveys (Huizinga, 2010, 2011, 2012, 2013, 2014; Huizinga and others, 2010; Richard Huizinga, unpub. data, 2014).

The measured angular offset for roll with the sonar head untilted (a head tilt of "none" in table 4) changed from -2.60 degrees to -2.90 degrees between the first and second patch tests (table 4), whereas the measured angular offset for pitch changed from -2.50 degrees to -1.50 degrees between the first and second patch tests (table 4). The changes in these offsets likely are the result of striking a spur dike that caused the mount to bend during the survey at structure A5664 on State Route 13 near Lexington, Mo. The measured angular offset for yaw also was affected, changing from 0.70 degrees to 2.20 degrees between the first and second patch tests (table 4). The offset values for roll, pitch, and yaw with the sonar head tilted 30 degrees to port and 30 degrees to starboard (" $30 \mathrm{deg}$ port" and "30 deg stbd," respectively, in table 4) show similar changes before and after striking the spur dike. It was noted in Huizinga (2010) that a sensitivity analysis of the four offsets implied that the ultimate position of surveyed points in threedimensional space was least sensitive to the angular offset 
Table 4. Patch test results from surveying on the Missouri River between Kansas City and St. Louis, Missouri.

[sec, seconds; deg, degrees; stbd, starboard]

\begin{tabular}{ccccccc}
\hline $\begin{array}{c}\text { Date of } \\
\text { test }\end{array}$ & $\begin{array}{c}\text { Timing offset } \\
\text { (sec) }\end{array}$ & $\begin{array}{c}\text { Angular offset } \\
\text { for roll } \\
\text { (deg) }\end{array}$ & $\begin{array}{c}\text { Angular offset } \\
\text { for pitch } \\
\text { (deg) }\end{array}$ & $\begin{array}{c}\text { Angular offset } \\
\text { for yaw } \\
\text { (deg) }\end{array}$ & Head tilt & Location \\
\hline $04 / 16 / 13$ & 0 & -2.60 & -2.50 & 0.70 & none & Indian Lake near Cuba, Missouri \\
$04 / 16 / 13$ & 0 & -32.75 & -1.90 & 0.70 & 30 deg stbd & Indian Lake near Cuba, Missouri \\
$04 / 16 / 13$ & 0 & 27.60 & -2.50 & 0.70 & 30 deg port & Indian Lake near Cuba, Missouri \\
$04 / 25 / 13$ & 0 & -2.90 & -1.50 & 2.20 & none & Missouri River at Miami, Missouri \\
$04 / 26 / 13$ & 0 & -33.20 & -1.50 & 2.20 & 30 deg stbd & Missouri River at Glasgow, Missouri \\
$04 / 26 / 13$ & 0 & 26.90 & -1.50 & 2.20 & 30 deg port & Missouri River at Glasgow, Missouri \\
\hline
\end{tabular}

for yaw, whereas it was most sensitive to the angular offset for roll.

The bathymetric data were processed to apply the offsets determined from the patch tests, and to remove data spikes and other spurious points in the multibeam swaths through the use of automatic filters and manual editing. The bathymetric data were then projected to a three-dimensional grid at a resolution of $1.64 \mathrm{ft}$. The bathymetric data were used to generate a gridded raster surface of the channel bed in the vicinity of each bridge (hereinafter referred to as a "bathymetric surface") using ArcGIS.

\section{Uncertainty Estimation}

To estimate the uncertainty in the surveys, the Combined Uncertainty Bathymetric Estimator (CUBE) method (Calder and Mayer, 2003), as implemented in the HYPACK ${ }^{\circledR} /$ HYSWEEP ${ }^{\circledR}$ software (HYPACK, Inc., 2011), was used to estimate total propagated uncertainty (TPU) for the bathymetric surface of each survey area. The CUBE method allows all random system component uncertainties and resolution effects to be combined and propagated through the data processing steps, which provides a robust estimate of the spatial distribution of possible uncertainty within the survey area (Czuba and others, 2011). Thus, the TPU of a point is a measure of the accuracy to be expected for such a point when all relevant error sources are taken into account (Czuba and others, 2011). Statistics of TPU for each of the survey areas are shown in table 5, and an example of the spatial distribution of TPU typically observed in the survey data is shown in figure 5 for the bathymetric data at structure A6288 on Missouri Highway 19 at Hermann, Mo.
The largest TPU in this group of Missouri River surveys was about $3.87 \mathrm{ft}$ (table 5); however, as noted in previous studies, TPU values of this magnitude typically occurred near high-relief features, such as the front or side of a pier footing (fig. 5). Most of the TPU values (more than 88 percent) were less than $1.00 \mathrm{ft}$ (table 5). Larger TPU values occur near moderate-relief features (banks, spur dikes, rock riprap and outcrops, and scour holes near piers; fig. 5). Occasionally, these larger TPU values also occurred in the outermost beam parts of the multibeam swath in the overlap with an adjacent swath, particularly when the MBES head was tilted for the survey lines along the banks (fig. 5). Overlapping adjacent swaths in the channel thalweg, the line of maximum depth in the channel, also can display larger TPU values because substantial bed movement can occur between survey passes, but this phenomenon was not observed at Hermann, Mo. (fig. 5). In contrast, the area around the piers with additional tilted head survey lines and the area of overlap between adjacent swaths display smaller values of TPU at Hermann, Mo. (fig. 5). Nearly one-half (49.8 percent or more) of the channel bed at the five upstream-most sites had TPU values of $0.50 \mathrm{ft}$ or less (table 5). The tops of bridge substructural elements (pier footings and seal courses) typically had TPU values of $0.50 \mathrm{ft}$ or less.

The survey at structure A6288 on Missouri Highway 19 at Hermann, Mo., had the highest mean and median values of TPU, as well as generally the lowest percentage of bathymetry points that were less than the various TPU value cutoffs (table 5). There were no substantial impediments to flow or surveying at this site and the survey was obtained with smooth longitudinal swathes (fig. 5), and that was the case at nearly all of the sites surveyed as part of this study. The magnitude and distribution of TPU values observed at this site are representative of those observed at all of the other surveyed sites. 
Table 5. Total propagated uncertainty results for bathymetric data at a 1.64-feet grid spacing from surveys on the Missouri River between Kansas City and St. Louis, Missouri, from April 22 through May 2, 2013.

[MoDOT, Missouri Department of Transportation; ft, feet]

\begin{tabular}{|c|c|c|c|c|c|c|c|c|c|}
\hline \multirow{2}{*}{$\begin{array}{c}\text { Site } \\
\text { number } \\
\text { (fig. 1) }\end{array}$} & \multirow{2}{*}{$\begin{array}{c}\text { MoDOT } \\
\text { structure } \\
\text { number }\end{array}$} & \multirow{2}{*}{$\begin{array}{l}\text { Maximum } \\
\text { value of } \\
\text { uncertainty } \\
\text { (ft) }\end{array}$} & \multirow{2}{*}{$\begin{array}{l}\text { Mean value } \\
\text { of uncer- } \\
\text { tainty } \\
\text { (ft) }\end{array}$} & \multirow{2}{*}{$\begin{array}{c}\text { Median } \\
\text { value of } \\
\text { uncertainty } \\
\text { (ft) }\end{array}$} & \multirow{2}{*}{$\begin{array}{c}\text { Standard } \\
\text { deviation of } \\
\text { uncertainty } \\
\text { (ft) }\end{array}$} & \multicolumn{4}{|c|}{$\begin{array}{l}\text { Percent of bathymetry points with } \\
\text { uncertainty value less than }\end{array}$} \\
\hline & & & & & & $2.00 \mathrm{ft}$ & $1.00 \mathrm{ft}$ & $0.50 \mathrm{ft}$ & $0.25 \mathrm{ft}$ \\
\hline 14 & A5664 & 3.58 & 0.57 & 0.49 & 0.43 & 97.3 & 93.5 & 61.2 & 1.3 \\
\hline 15 & A5910 & 3.44 & 0.66 & 0.52 & 0.51 & 96.0 & 88.7 & 49.8 & 0.3 \\
\hline 16 & K0999 & 3.48 & 0.63 & 0.49 & 0.54 & 95.1 & 88.5 & 54.7 & 6.5 \\
\hline 17 & G0069 & 3.58 & 0.61 & 0.49 & 0.49 & 96.4 & 91.3 & 55.5 & 0.1 \\
\hline 18 & A4574 & 3.51 & 0.63 & 0.49 & 0.52 & 95.7 & 90.9 & 56.4 & 0.2 \\
\hline 19 & L0962 & 3.64 & 0.67 & 0.56 & 0.44 & 97.0 & 91.7 & 32.0 & 0.2 \\
\hline 20 & L0550/A4497 & 3.77 & 0.63 & 0.52 & 0.43 & 97.0 & 91.6 & 42.4 & 1.0 \\
\hline 21 & A6288 & 3.58 & 0.71 & 0.59 & 0.47 & 96.5 & 89.6 & 25.6 & 0.3 \\
\hline 22 & K0969 & 3.87 & 0.71 & 0.59 & 0.47 & 96.6 & 90.7 & 27.8 & 0.2 \\
\hline
\end{tabular}

\section{Results of Bathymetric and Velocimetric Surveys}

The site-specific results for each bridge are discussed in the following sections starting with the upstream-most bridge site and progressing downstream, followed by a discussion of general findings that are not specific to a particular site. The range of bed elevations described as "the channel-bed elevations" for each survey was based on statistical analysis of the bathymetry data at each site, and covers the percentile range from 5 to 95 percent of the data. Because the surveys generally were limited to the active channel between banks and spur dikes, and excluded overbank areas, this percentile range generally covered the channel bed but excluded the banks and localized high or low spots, such as spur dikes or scour holes near piers. All elevation data were referenced to the North American Vertical Datum of 1988 (NAVD 88).

For consistency with earlier studies, dune sizes are described in general terms for each of the bridge sites using the categories set by Huizinga (2012) for the discussion of bathymetry during the 2011 flood. In this report, small dunes and ripples are those that are less than $5 \mathrm{ft}$ high from crest to trough, medium dunes are those that are 5 to $10 \mathrm{ft}$ high, large dunes are those that are 10 to $15 \mathrm{ft}$ high, and very large dunes are those that are $15 \mathrm{ft}$ or more in height. The reader is advised that these ranges are different than those used by Richardson and Davis (2001; wherein a "small" dune is 2 to $10 \mathrm{ft} \mathrm{high,}$ "medium" is 10 to $30 \mathrm{ft}$ high, and "large" is greater than $30 \mathrm{ft}$ high), but are used herein to provide more descriptive definition of the dune sizes.

All of the bridge sites were the subject of previous bathymetric surveys (Huizinga, 2012), and may have had a Level II bridge scour assessment (Lagasse and others, 1991; Huizinga and Rydlund, 2004). A map showing the change in channel-bed elevation is included for each site, and data from the previous survey is included in the cross-section plot for that bridge. If a Level II assessment was performed at the site, the cross section of the channel on the downstream side of the bridge obtained during the Level II assessment is included on the cross-section plot for that bridge.

When discussing the vertically averaged velocity values obtained during the surveys in the sections that follow, neighboring vectors having random variations in direction and magnitude were taken as an indication of turbulence in the transect. Conversely, neighboring vectors having gradual and systematic variations were taken as an indication of uniform flow in the transect.

Shaded triangulated irregular network (TIN) images were prepared of the channel and side of pier for each surveyed pier. These visualizations are shown in the appendix figures 1-1 to $1-9$. 


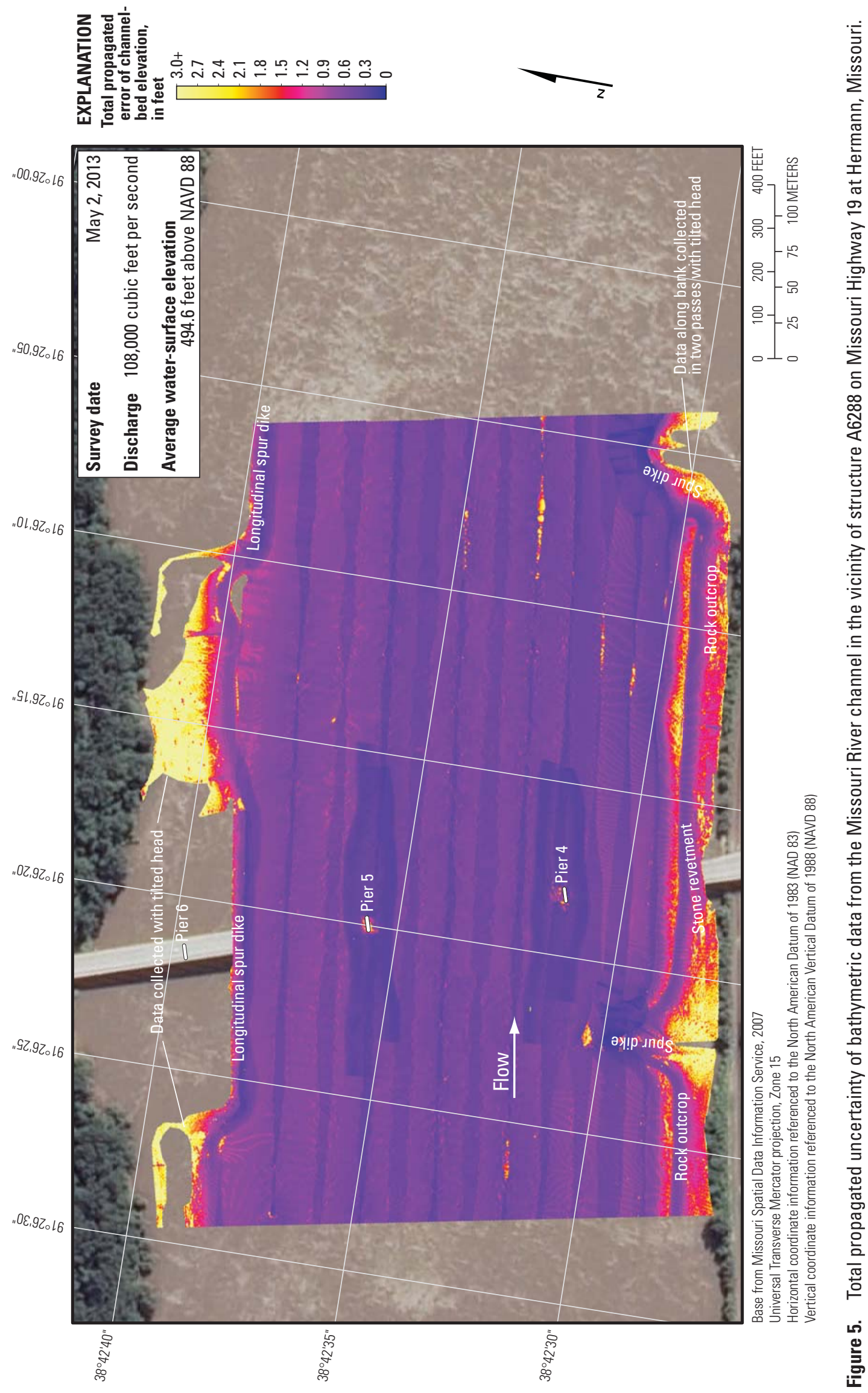




\section{Structure A5664 on State Highway 13 at Lexington, Missouri}

Structure A5664 (site 14) on State Highway 13 crosses the Missouri River at river mile (RM) 314.9 at Lexington, Mo., east of Kansas City, Mo. (fig. 1; table 1). The site was surveyed on April 24, 2013, and the average water-surface elevation of the river in the survey area, determined by the RTK GNSS tide solution, was $675.4 \mathrm{ft}$ (table 2). Discharge on the Missouri River was about $41,100 \mathrm{ft}^{3} / \mathrm{s}$ during the survey (table 2).

The survey area was about 1,640 ft long and about $800 \mathrm{ft}$ wide, extending from the left (north) bank to about $150 \mathrm{ft}$ to the right of the tips of the spur dikes on the right (south) side of the main channel (fig. 6). The upstream end of the survey area was about $670 \mathrm{ft}$ upstream from the centerline of structure A5664, and pier 21 and 22 were in the water and away from the banks (fig. 6); however, pier 22 was in shallow water (fig. 6). The channel-bed elevations ranged from about 655 to $666 \mathrm{ft}$ for most of the surveyed area ( 5 to 95 percentile range of the bathymetric data), except in the vicinity of the spur dikes on the right (south) bank (fig. 6; table 2). The channel bed between the left bank and the spur dikes was filled with small and medium dune features, and small dunes and ripples were present in the area between the spur dikes on the right side of the channel (fig. 6). Large scour holes were present downstream from the spur dikes on the right side (fig. 6).

The minor scour hole in the vicinity of main channel pier 21 was difficult to discern from nearby dunes and ripples (fig. 6). Information from bridge plans indicates that piers 21 and 22 are founded on shafts drilled 28 to $50 \mathrm{ft}$ into bedrock, having about $52 \mathrm{ft}$ of bed material between the channel bottom and bedrock at pier 21, and about $31 \mathrm{ft}$ of material at pier 22 (fig. 7; table 6). The surveyed bed generally was higher along the upstream bridge face than the original ground line in 1999 from bridge plans and the previous multibeam survey on July 20, 2011, with 5 to $10 \mathrm{ft}$ of deposition between the left bank and pier 21 , and 5 to $15 \mathrm{ft}$ of deposition between piers 21 and 22 (fig. 7).

The difference between the bathymetric surfaces from the surveys on April 24, 2013, and July 20, 2011 (fig. 8), indicates substantial deposition of as much as $15 \mathrm{ft}$ has occurred throughout the channel, but having small areas of scour near the tips of the spur dikes on the right (south) side of the channel. The mean difference between the July 2011 and April 2013 bathymetric surfaces $(4.35 \mathrm{ft}$; table 7$)$ indicates moderate to substantial deposition overall, as evident in the difference map (fig. 8). There was as much as $15 \mathrm{ft}$ of deposition on the right bank downstream from the spur dikes, and as much as $20 \mathrm{ft}$ of scour near the tips of the spur dikes (fig. 8). About $5 \mathrm{ft}$ of deposition was observed on the stone revetment on the left bank (fig. 8).

The vertically averaged velocity vectors indicate mostly uniform flow throughout most of the channel, ranging from about 3 to $5 \mathrm{ft} / \mathrm{s}$, except downstream from the spur dikes on the right bank (fig. 9). Minimal to moderate turbulence was observed at several transects (fig. 9), likely as a result of flow disturbances caused by the spur dikes. The bridge piers were aligned with flow, with no evident turbulence downstream from pier 21 (fig. 9), similar to what had been observed in 2013.

\section{Structure A5664 on State Highway 13 at Lexington, Missouri.}




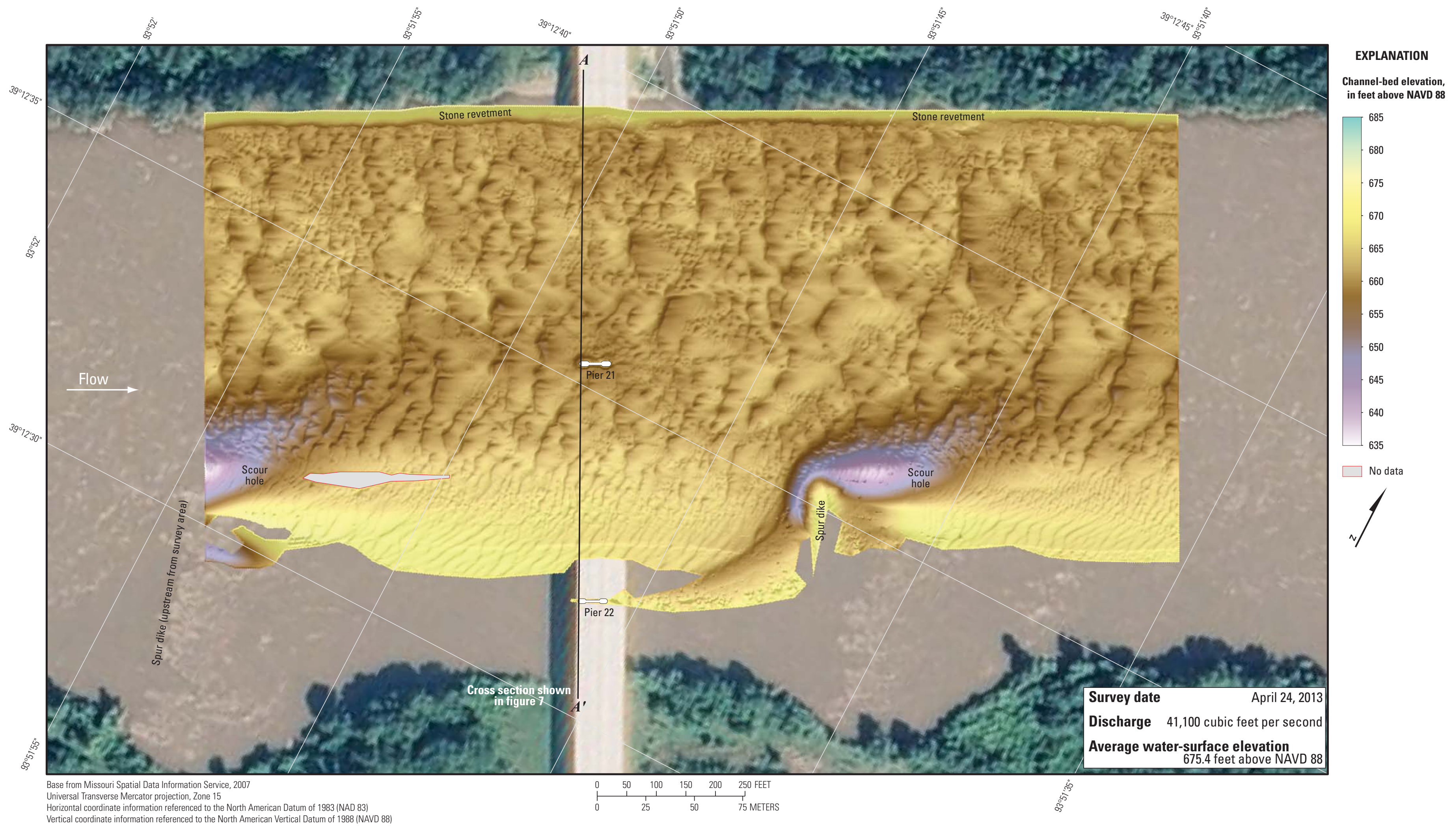

Figure 6. Bathymetric survey of the Missouri River channel in the vicinity of structure A5664 on State Highway 13 at Lexington, Missouri. 


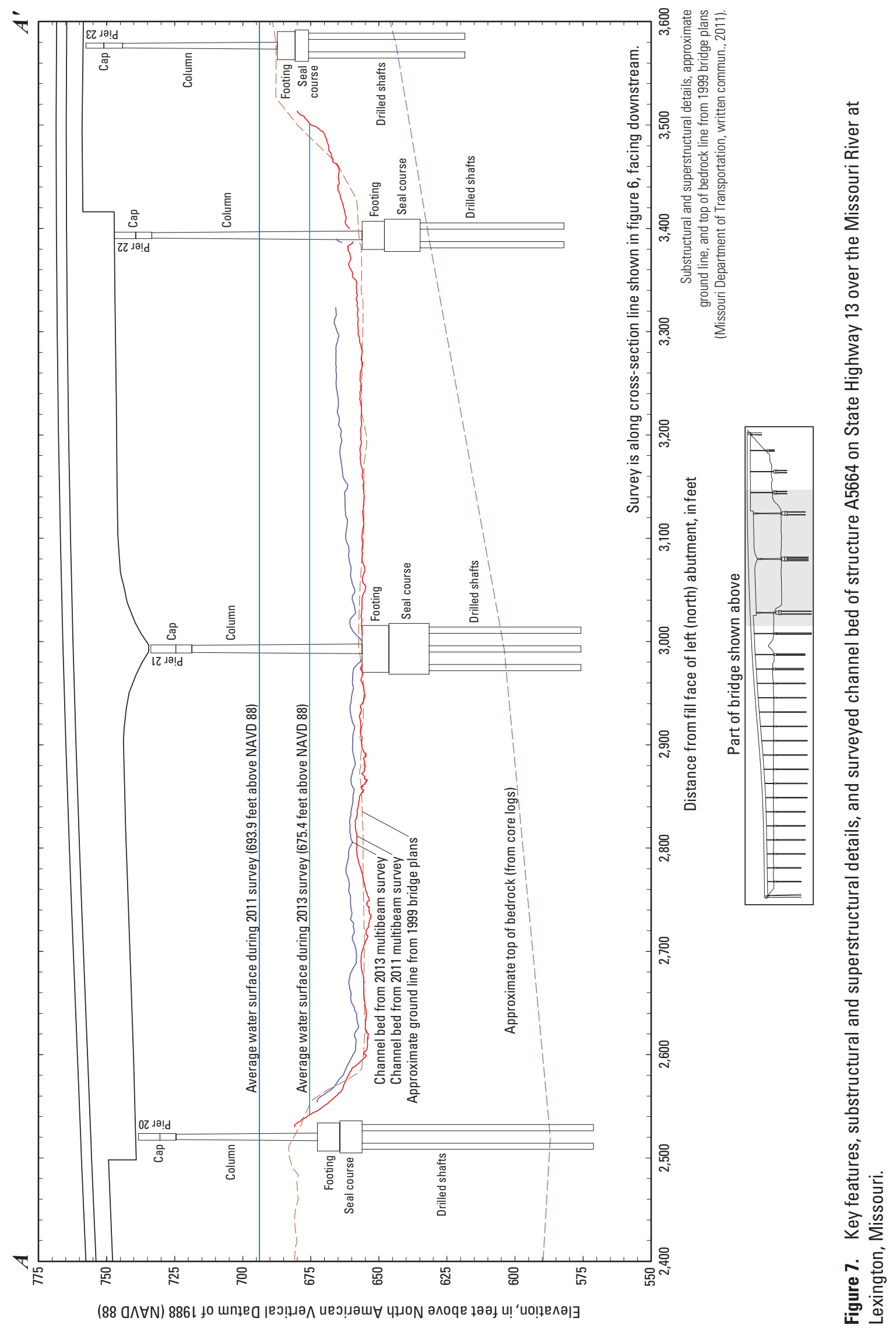



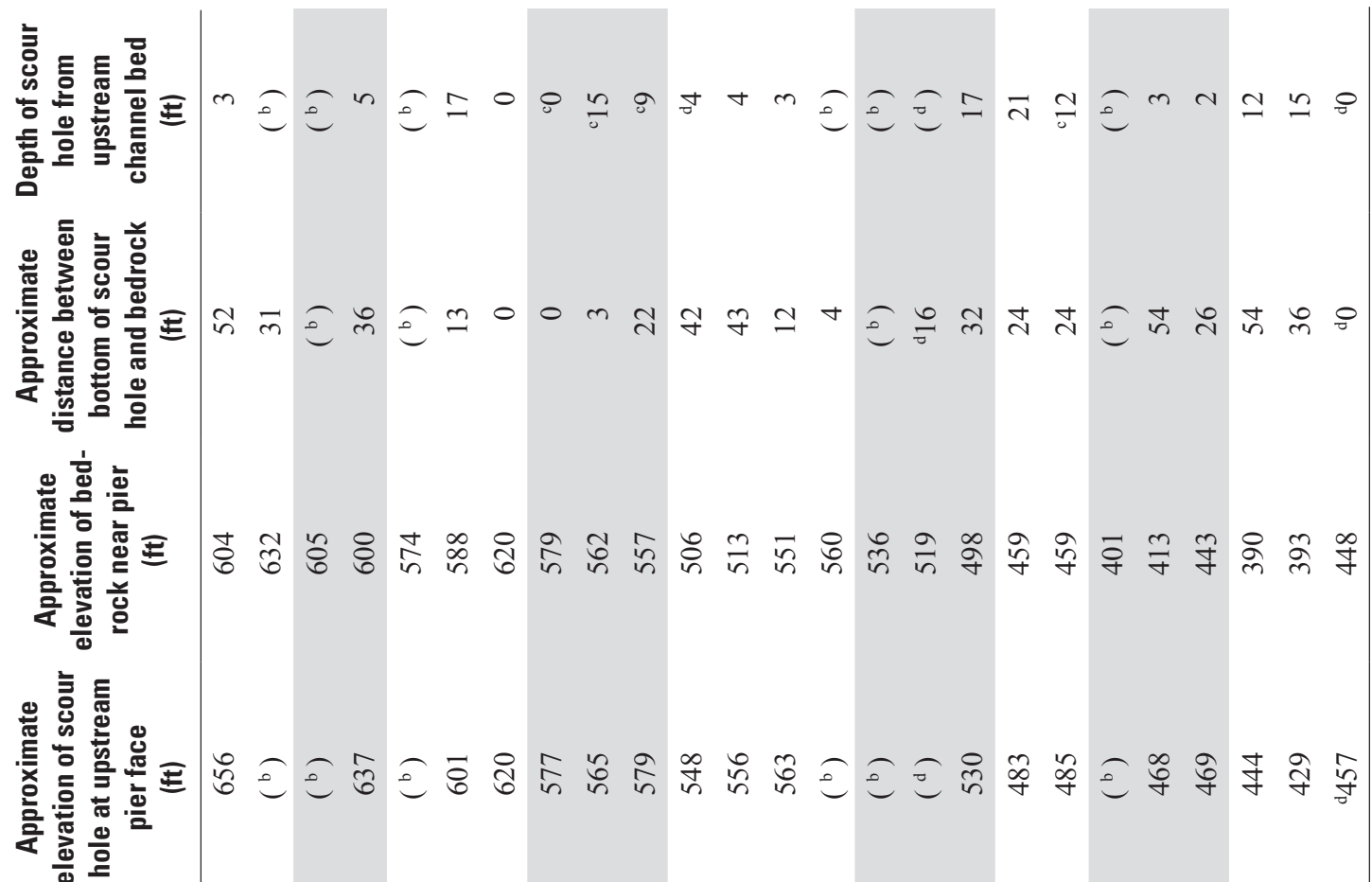

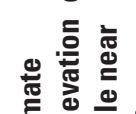

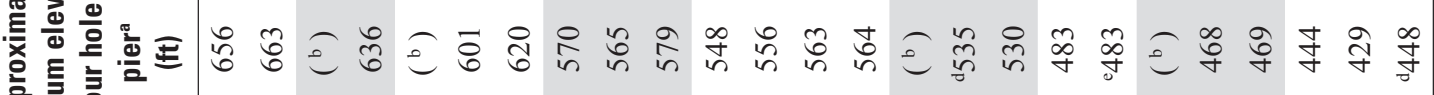

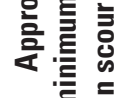

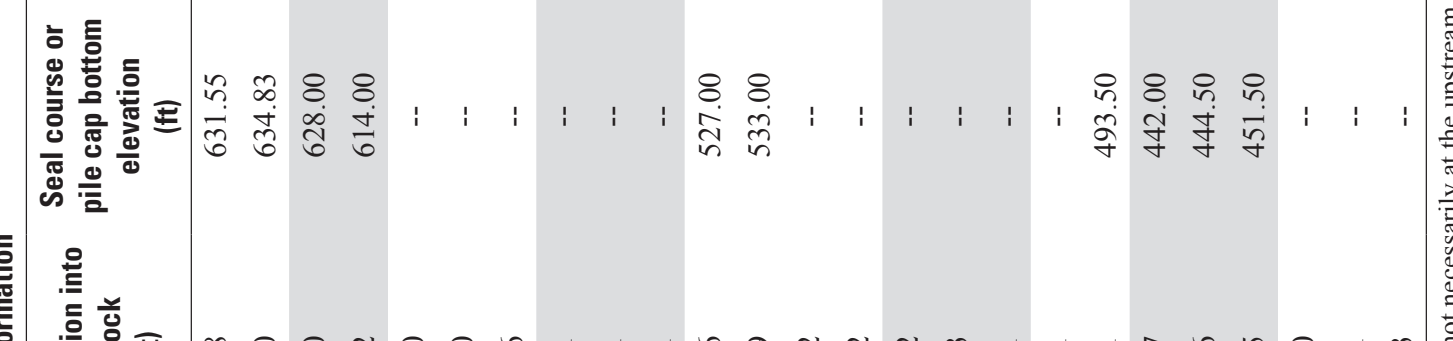

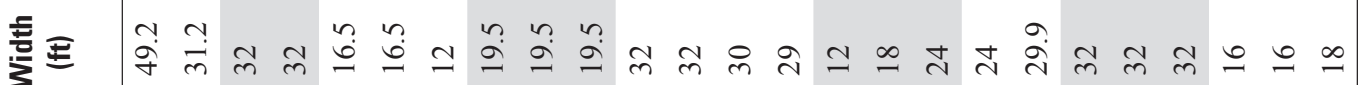




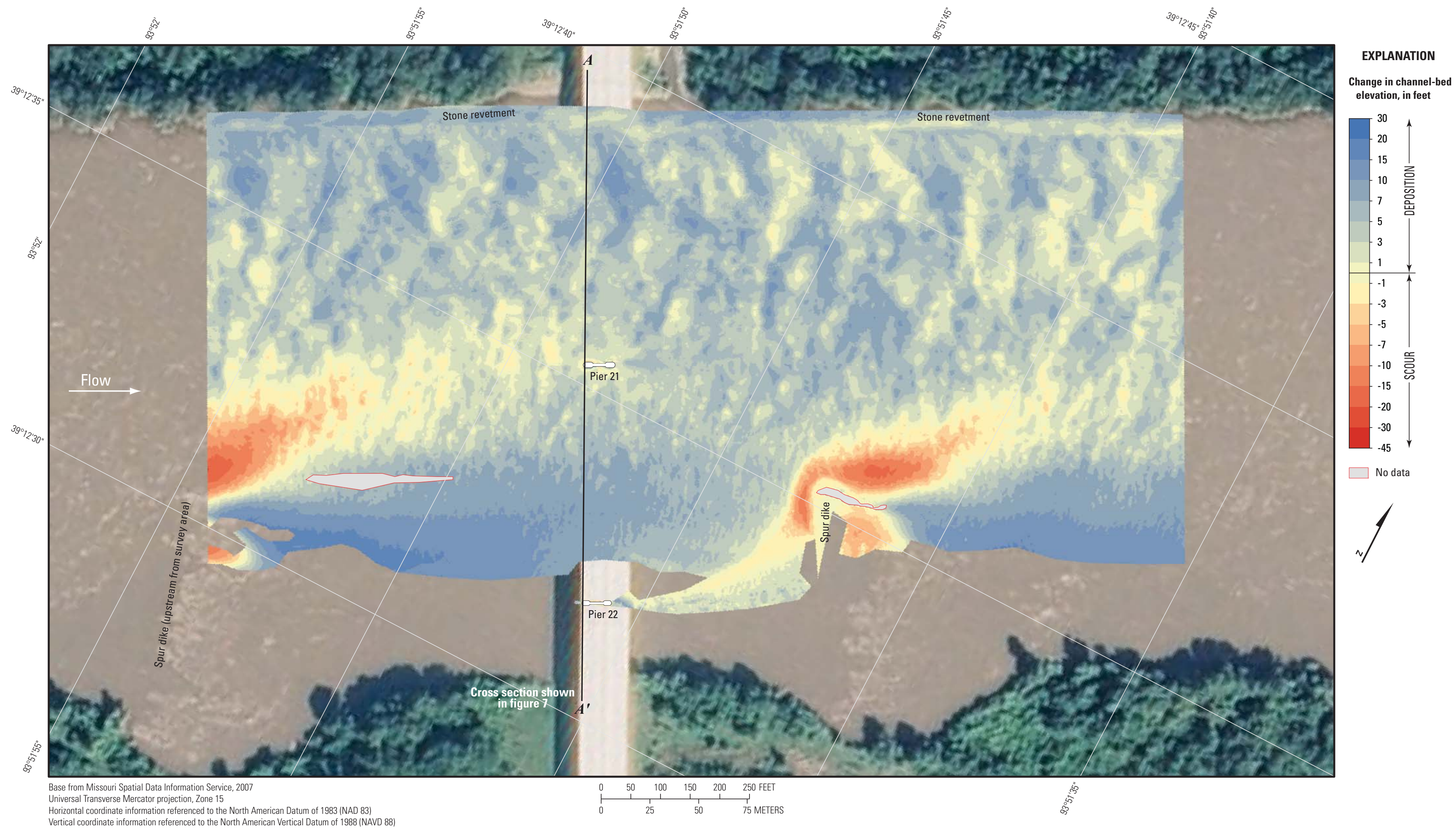

Figure 8. Difference between bathymetric surfaces created from surveys of the Missouri River channel in the vicinity of structure A5664 on State Highway 13 at Lexington, Missouri, on April 24, 2013, and July 20, 2011. 


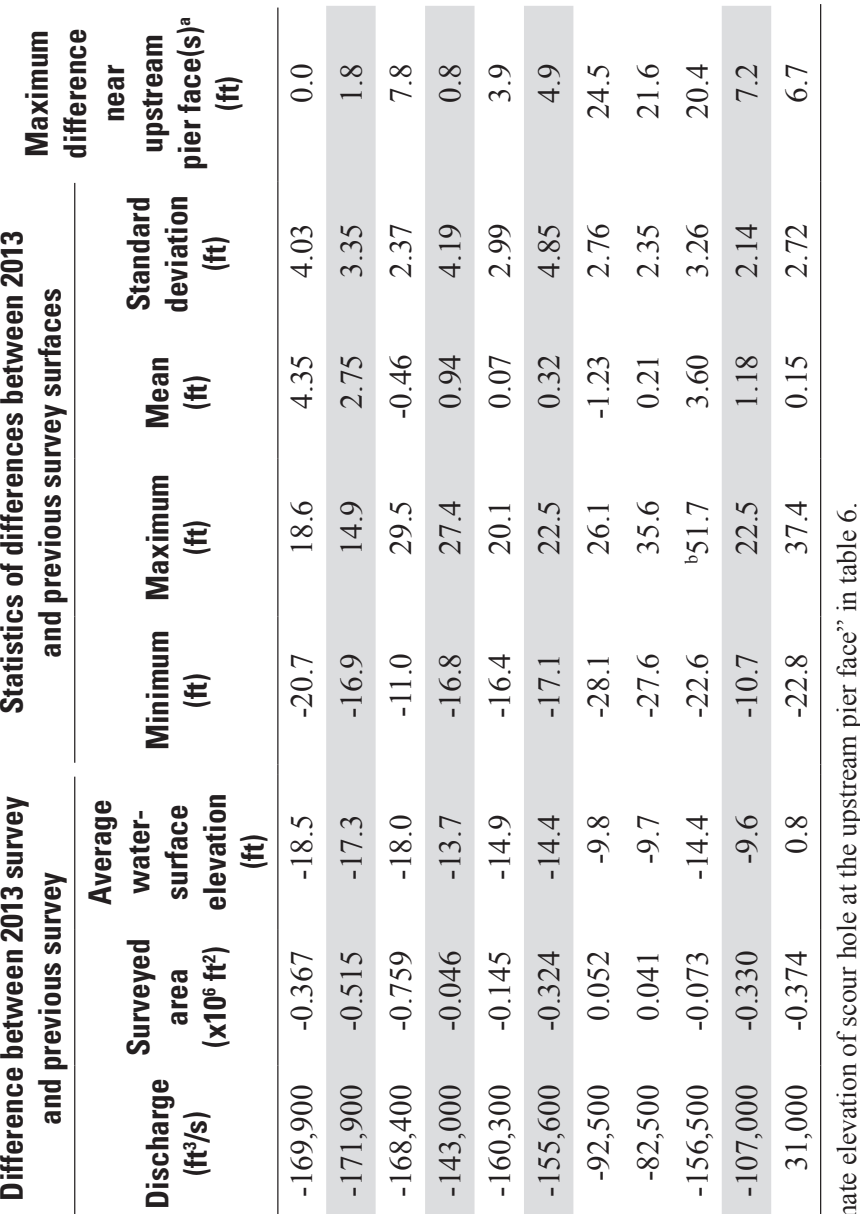

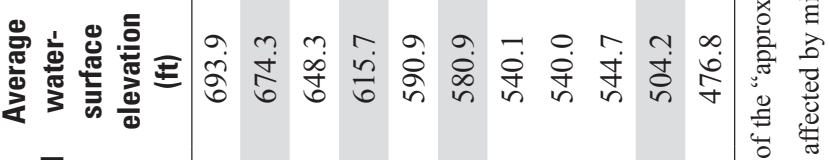

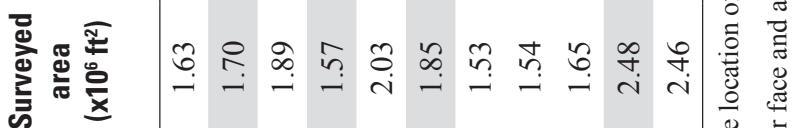




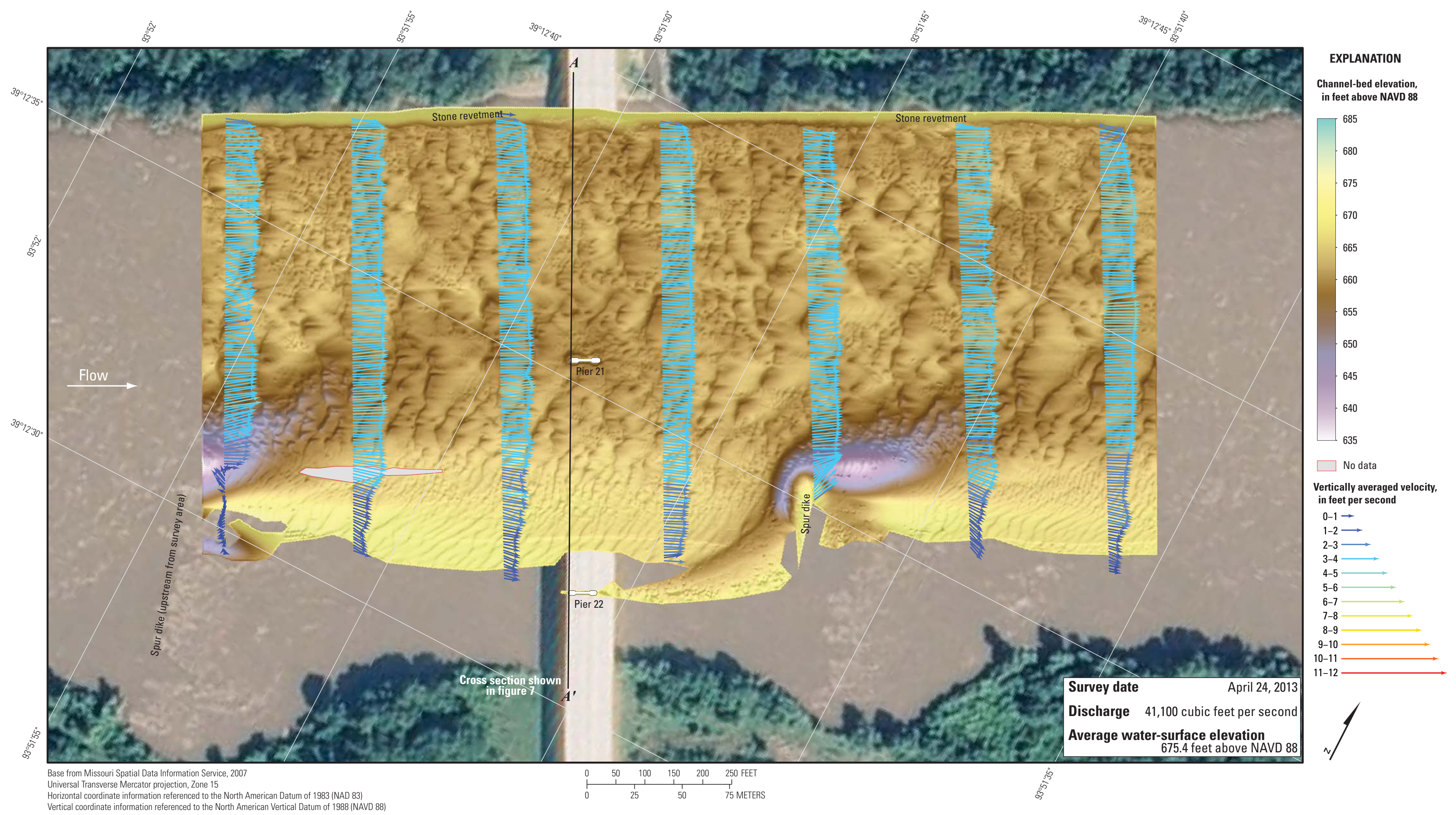

Figure 9. Bathymetry and vertically averaged velocities of the Missouri River channel in the vicinity of structure A5664 on State Highway 13 at Lexington, Missouri. 


\section{Structure A5910 on U.S. Highway 24 at Waverly, Missouri}

Structure A5910 (site 15) on U.S. Highway 24 crosses the Missouri River at RM 293.2 at Waverly, Mo., east of Lexington and Kansas City, Mo. (fig. 1; table 1). The site was surveyed on April 25, 2013, and the average water-surface elevation of the river in the survey area, determined by the RTK GNSS tide solution, was $657.0 \mathrm{ft}$ (table 2). Discharge on the Missouri River was about 41,100 $\mathrm{ft}^{3} / \mathrm{s}$ during the survey (table 2).

The survey area was about 1,640 ft long and about $765 \mathrm{ft}$ wide, extending from about $125 \mathrm{ft}$ to the left of the tips of the spur dikes on the left (north) bank to the right (south) bank in the main channel (fig. 10). The upstream end of the survey area was about $650 \mathrm{ft}$ upstream from the centerline of structure A5910, and piers 10 and 11 were in the water and away from the banks (fig. 10); however, pier 10 was in shallow water (fig. 10). The channel-bed elevations ranged from about 637 to $649 \mathrm{ft}$ for most of the surveyed area (5 to 95 percentile range of the bathymetric data), except in the vicinity of the upstream spur dike on the left bank (fig. 10; table 2). A shallow thalweg was present along the right bank throughout the reach, and numerous medium and small dunes and ripples were present throughout the channel (fig. 10).

The minor scour hole near pier 10 was difficult to discern from nearby dunes and ripples (figs. 10 and 11). Information from bridge plans indicates that piers 10 and 11 are founded on shafts drilled 30 to $42 \mathrm{ft}$ into bedrock, having about $36 \mathrm{ft}$ of bed material between the bottom of the scour hole and bedrock at pier 11 (fig. 11; table 6). The surveyed bed generally was higher along the upstream bridge face than the original ground line in 1999 from bridge plans and the previous multibeam survey on July 20, 2011, with 5 to $10 \mathrm{ft}$ of deposition to the left of pier 11, and 5 to $15 \mathrm{ft}$ of deposition between piers 11 and the right bank (fig. 11).

The difference between the surveys on April 25, 2013, and July 21, 2011 (fig. 12), indicates moderate deposition of as much as $15 \mathrm{ft}$ has occurred particularly in the thalweg along the right bank, with small areas of scour near the tip and downstream from the spur dike on the upstream left side of the channel. The mean difference between the July 2011 and April 2013 bathymetric surfaces ( $2.75 \mathrm{ft}$; table 7$)$ indicates moderate deposition overall, as evident in the difference map (fig. 12). The series of large dunes evident in the July 2011 survey is indicated by a series of alternating scour and deposition patches along the left side of the channel (fig. 12). As much as $20 \mathrm{ft}$ of scour was observed near the upstream spur dike (fig. 12). No deposition was observed on the stone revetment or the longitudinal spur dike on the right bank (fig. 12).

The vertically averaged velocity vectors indicate mostly uniform flow throughout most of the channel, with velocities ranging from about 3 to $5 \mathrm{ft} / \mathrm{s}$ (fig. 13), except downstream from the upstream spur dike on the left bank. Minimal turbulence was observed in the channel, except for local flow deflection and reversal near the tip of the upstream spur dike (fig. 13). The bridge piers were aligned with flow, with no evident turbulence downstream from pier 11 (fig. 13), similar to what had been observed in 2013 .

Structure A5910 on U.S. Highway 24 at Waverly, Missouri. 


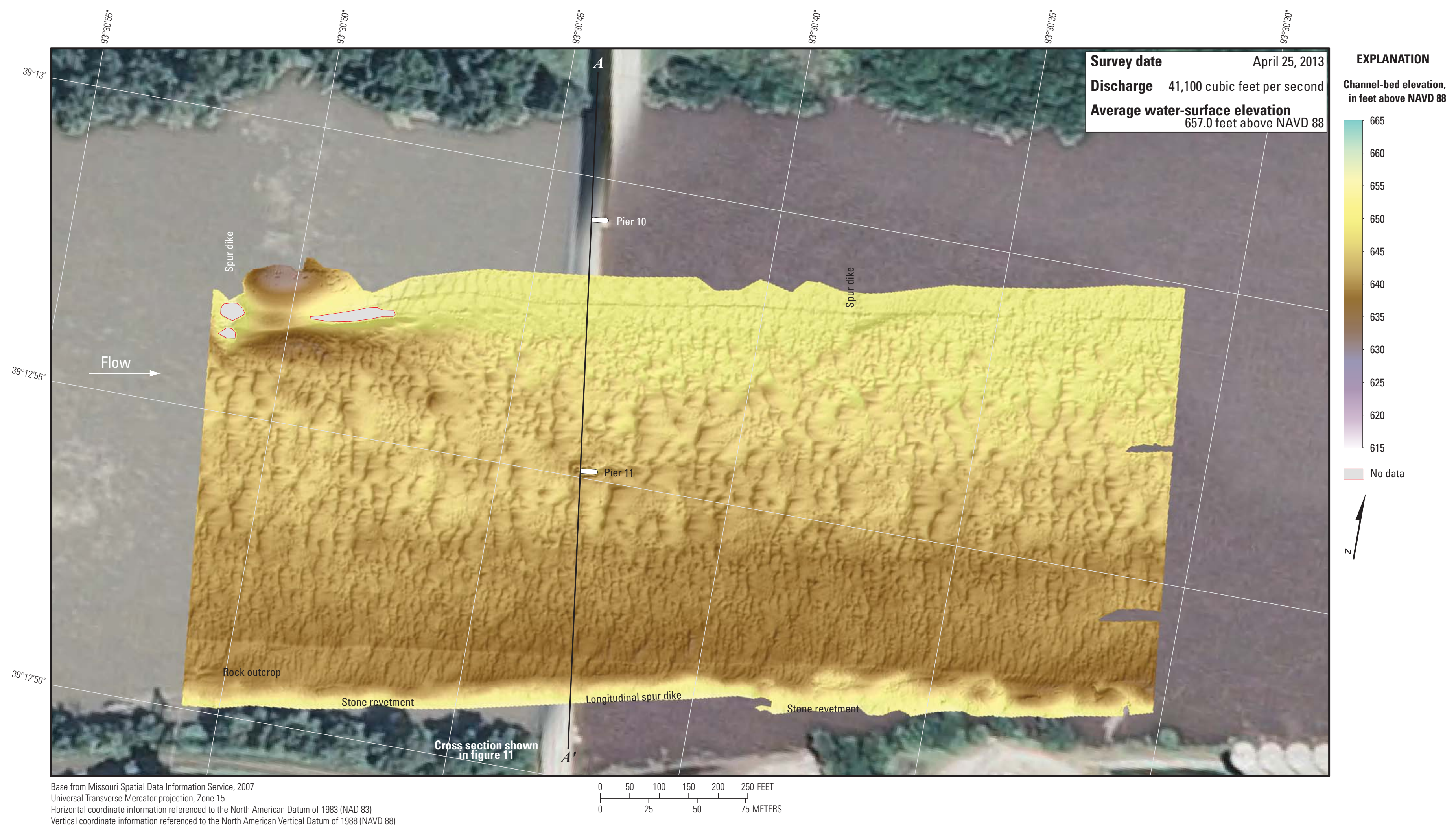

Figure 10. Bathymetric survey of the Missouri River channel in the vicinity of structure A5910 on U.S. Highway 24 at Waverly, Missouri. 


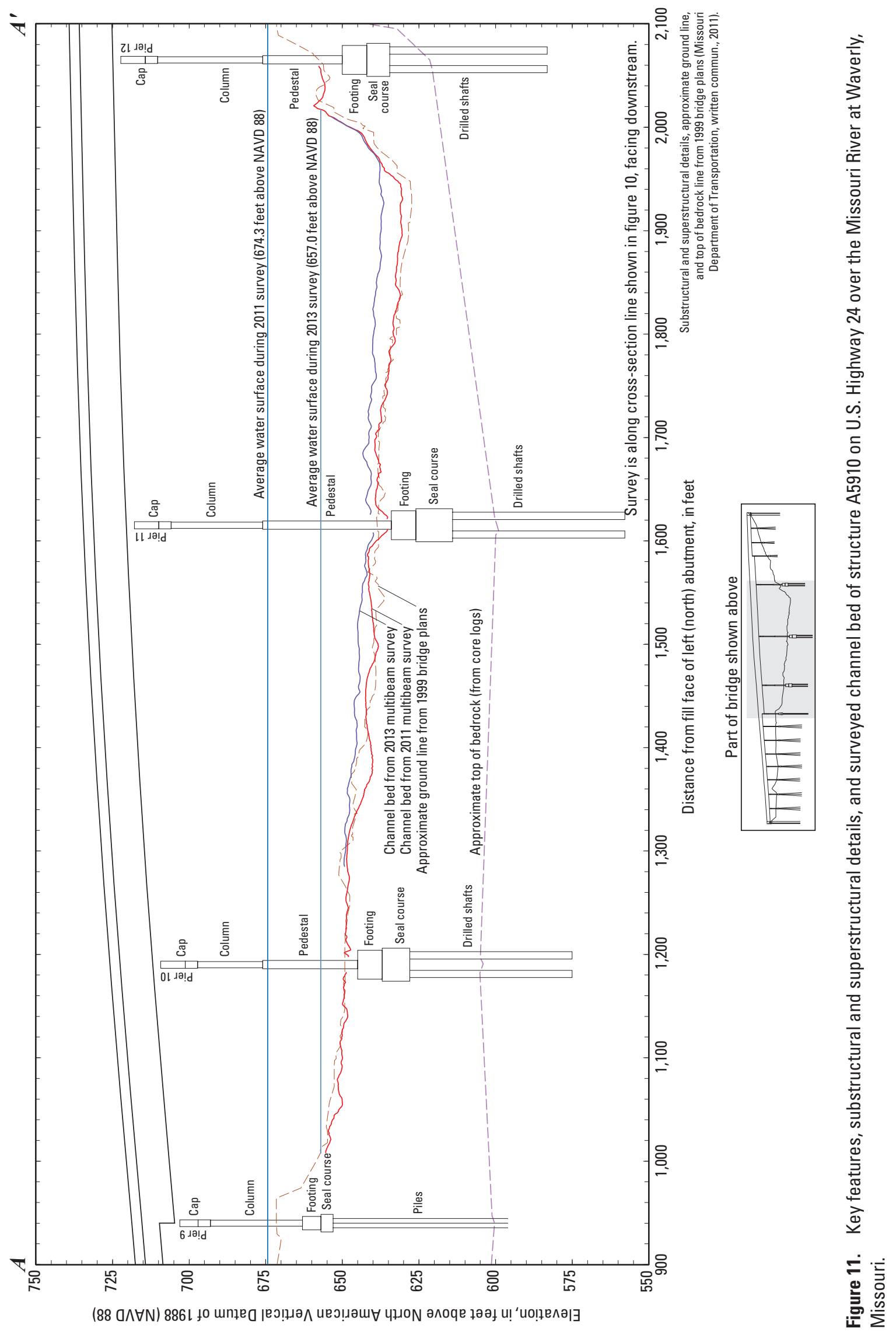




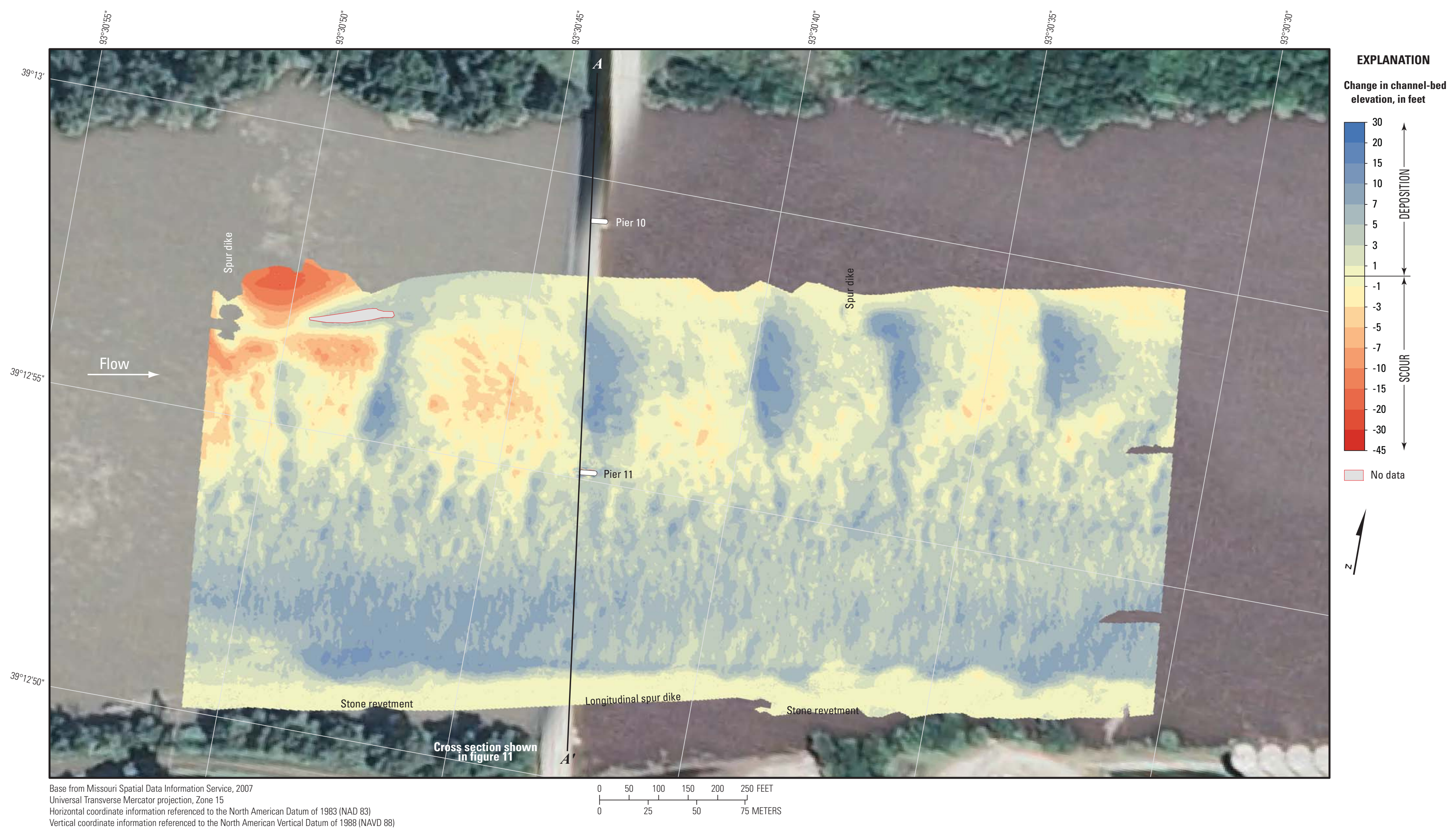

Figure 12. Difference between bathymetric surfaces created from surveys of the Missouri River channel in the vicinity of structure A5910 on U.S. Highway 24 at Waverly, Missouri, on April 25, 2013, and July 21, 2011. 


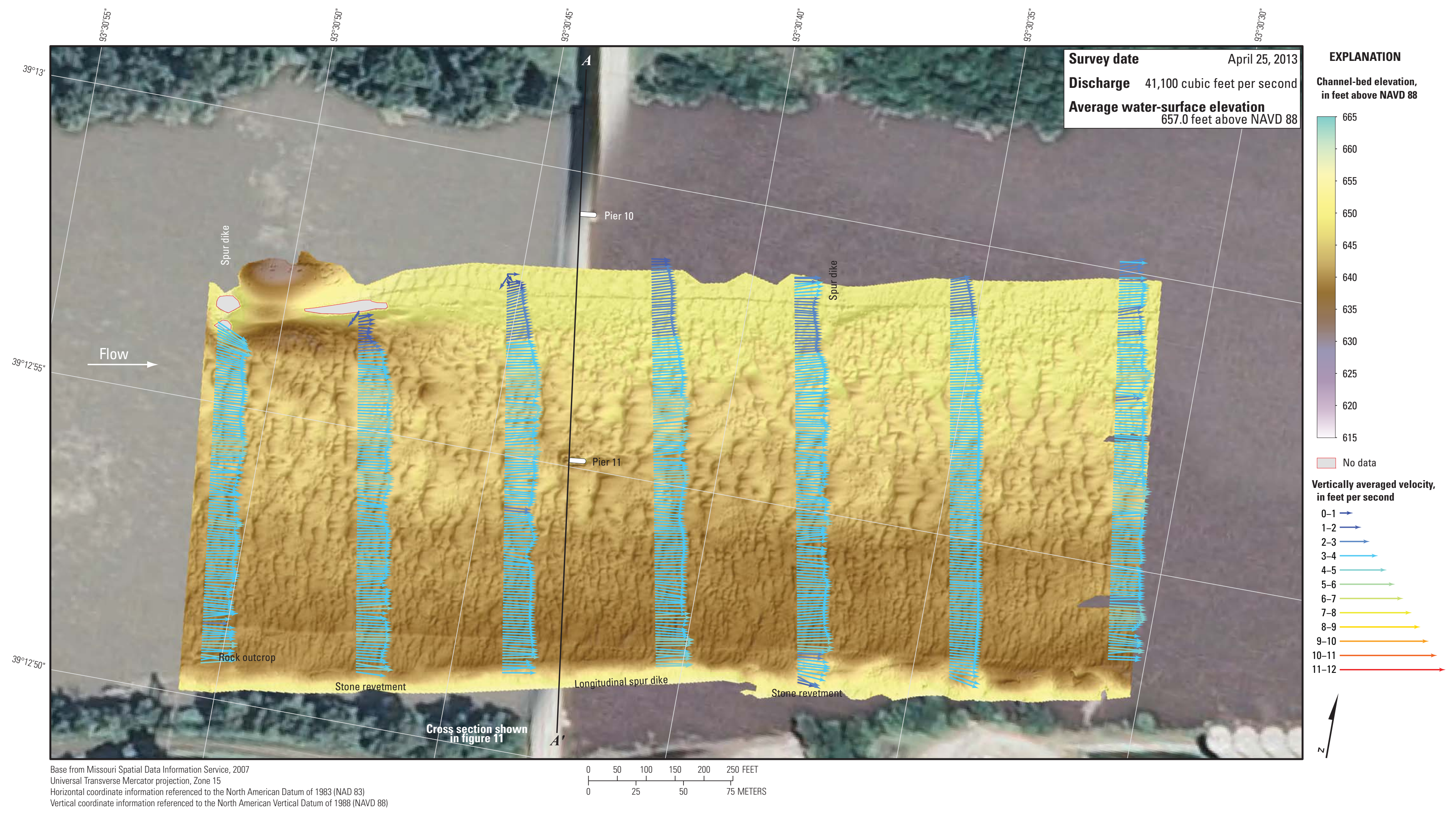

Figure 13. Bathymetry and vertically averaged velocities of the Missouri River channel in the vicinity of structure A5910 on U.S. Highway 24 at Waverly, Missouri. 


\section{Structure K0999 on State Highway 41 at Miami, Missouri}

Structure K0999 (site 16) on State Highway 41 crosses the Missouri River at RM 262.6 at Miami, Mo., east of Waverly and Kansas City, Mo. (fig. 1, table 1). The site was surveyed on April 25, 2013, and the average water-surface elevation of the river in the survey area, determined by the RTK GNSS tide solution, was $630.3 \mathrm{ft}$ (table 2). Discharge on the Missouri River was about 44,600 $\mathrm{ft}^{3} / \mathrm{s}$ during the survey, but this value may be skewed high by a large area of estimated discharge on the left side of the channel (table 2).

The survey area was about 1,640 ft long, and about $720 \mathrm{ft}$ wide, extending from a shallow area along the left side of the main channel about $400 \mathrm{ft}$ from the left (north) bank to the right (south) bank in the main channel (fig. 14). The upstream end of the survey area was about $625 \mathrm{ft}$ upstream from the centerline of structure K0999, and piers 4 through 6 were in the water and away from the banks (fig. 14); however, pier 6 was in the shallow water on the left side of the channel (fig. 14). The channel-bed elevations ranged from about 606 to $625 \mathrm{ft}$ for most of the surveyed area (5 to 95 percentile range of the bathymetric data), except in the channel thalweg along the right bank that reached a minimum channel-bed elevation of about $601 \mathrm{ft}$ (fig. 14; table 2). The thalweg was about 15 to $20 \mathrm{ft}$ deeper than the channel bed on the left side (fig. 14). A substantial area of exposed bedrock was present on the right bank, and a few medium dune features were detected in the thalweg along the interface with the exposed bedrock, along with numerous small dunes and ripples present throughout the rest of the channel (fig. 14).

A moderate scour hole was observed in the vicinity of pier 5 , and had a minimum channel-bed elevation of about $601 \mathrm{ft}$ (figs. 14, 15; table 6). Information from bridge plans indicates that pier 5 is a caisson founded on bedrock, having about $13 \mathrm{ft}$ of bed material between the bottom of the scour hole and bedrock at pier 5 (fig. 15; table 6). Pier 4 is founded on a footing on bedrock according to bridge plans (fig. 15; table 6), and no scour hole was observed near the pier (fig. 14). The surveyed bed along the cross section generally was about $5 \mathrm{ft}$ lower than the previous multibeam survey in 2011, except near the piers, making it more similar to the ground line from the Level II bridge scour assessment in 2002 (Huizinga, 2004; fig. 15). The approximate top-of-bedrock line from bridge plans confirms that the fluvial material near the right bank has washed away, exposing the bedrock along the thalweg (fig. 15). In modern construction, bridge substructural elements usually are pinned or socketed to bedrock (American Association of State Highway Transportation Officials, 2012; Brown and others, 2010), but full exposure of usually buried substructural elements warrants special consideration and observation.

The difference between the surveys on April 25, 2013, and July 21, 2011 (fig. 16), indicates a rough balance between scour and deposition throughout the channel. The mean difference between the July 2011 and April 2013 bathymetric surfaces (-0.46 ft; table 7) indicates mild deposition overall, as evident in the difference map (fig. 16). In the difference map, the appearance of substantial deposition or scour near the piers results from minor horizontal positional variances between the surveys (fig. 16); however, there was almost $8 \mathrm{ft}$ of deposition in the scour hole near pier 5 (fig. 16). The series of large dunes evident in the July 2011 survey is indicated by a series of alternating scour and deposition patches along the middle of the survey (fig. 16). Little to no deposition was observed on the stone revetment on the right bank (fig. 16).

The vertically averaged velocity vectors indicate mostly uniform flow throughout the channel, with velocities ranging from about 3 to $7 \mathrm{ft} / \mathrm{s}$ (fig. 17). Velocities were greater in the thalweg, and lower in the shallow area on the left side of the channel (fig. 17). Moderate turbulence and flow reversal was observed downstream from the longitudinal spur dike on the downstream right bank (fig. 17), and flow was deflected towards the right in the upstream reach, likely affected by the spur dike there (fig. 17). The bridge piers were aligned with flow, with no evident turbulence downstream from any pier (fig. 17).

Structure K0999 on State Highway 41 at Miami, Missouri. 


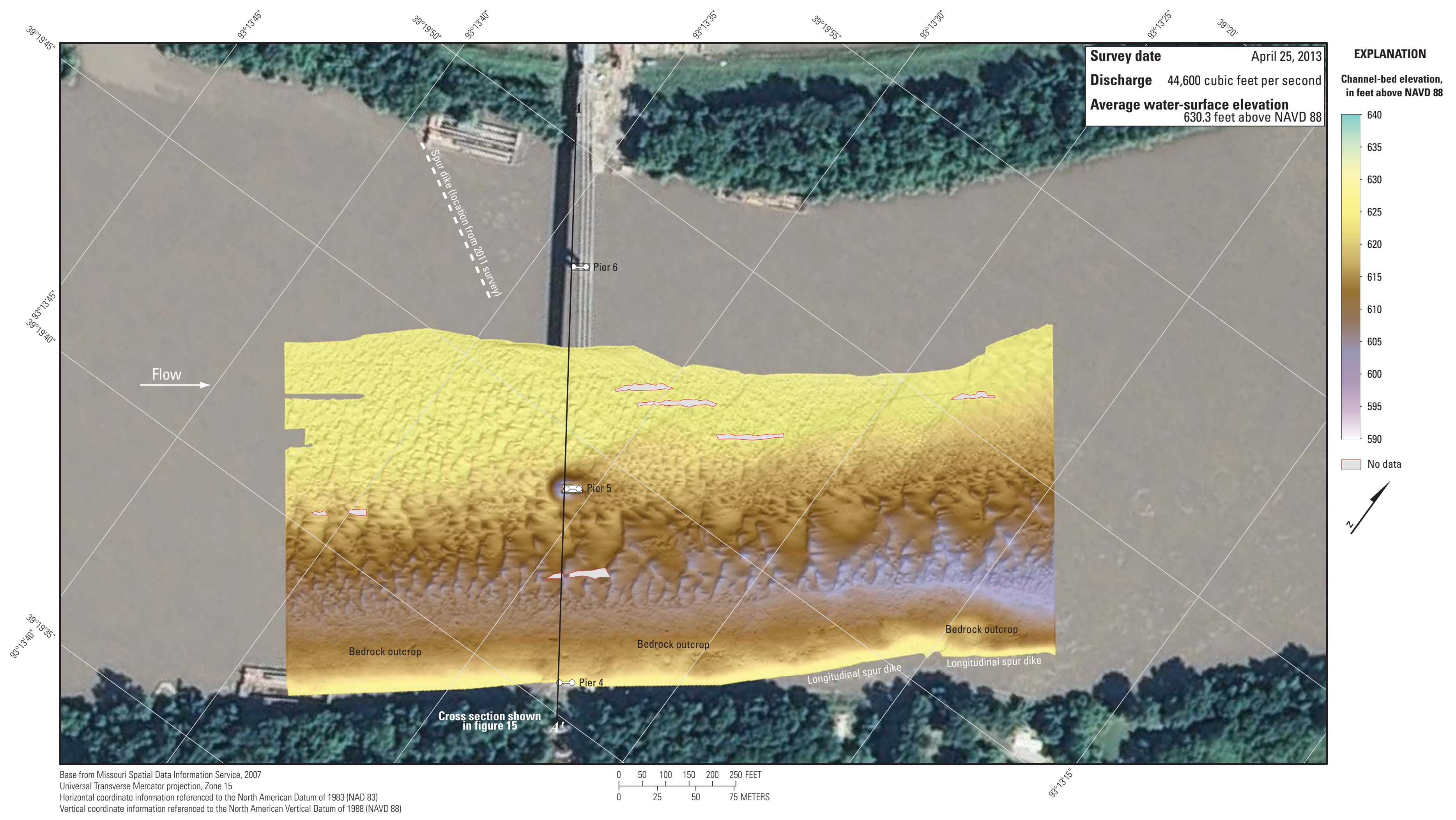

Figure 14. Bathymetric survey of the Missouri River channel in the vicinity of structure K0999 on State Highway 41 at Miami, Missouri. 


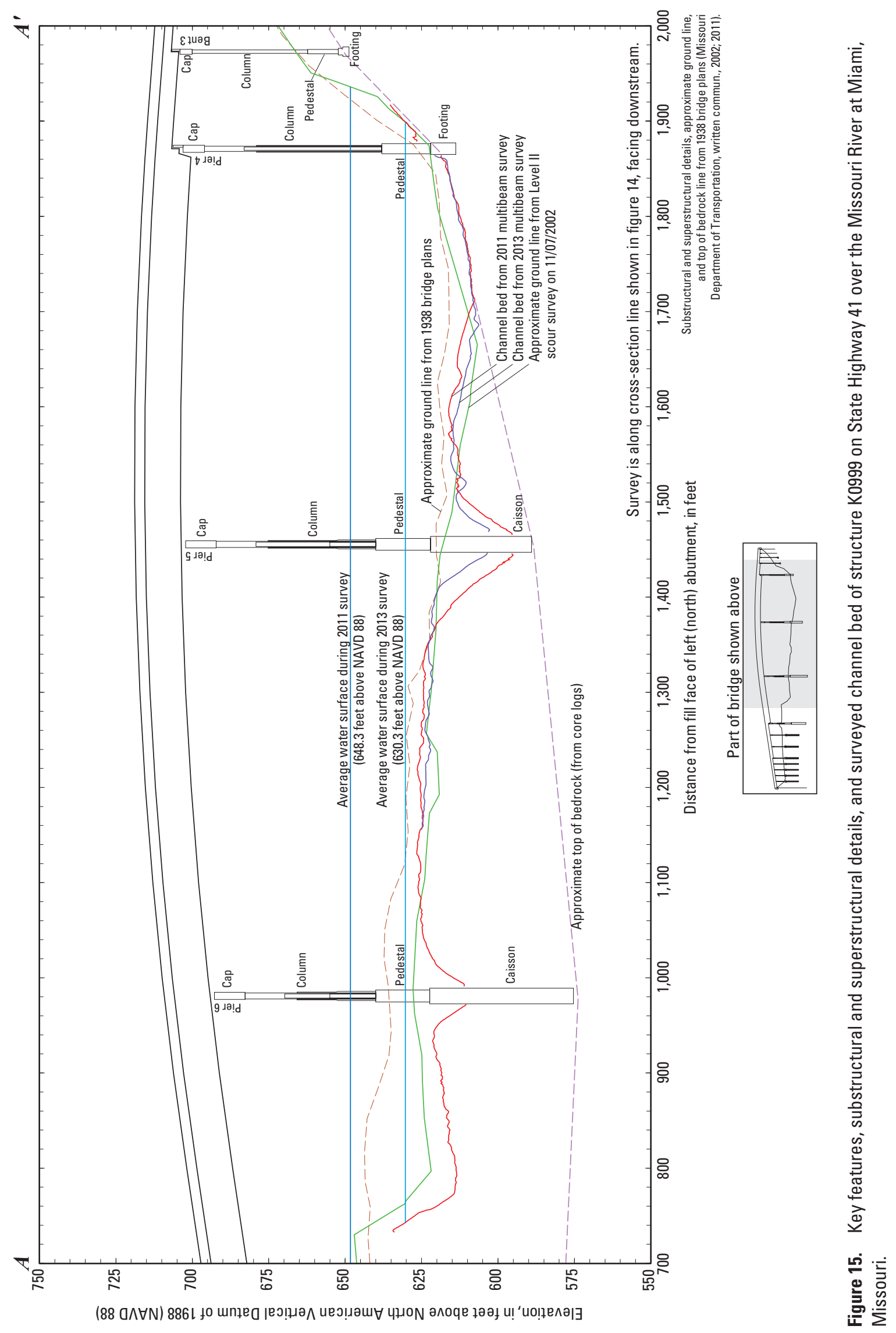




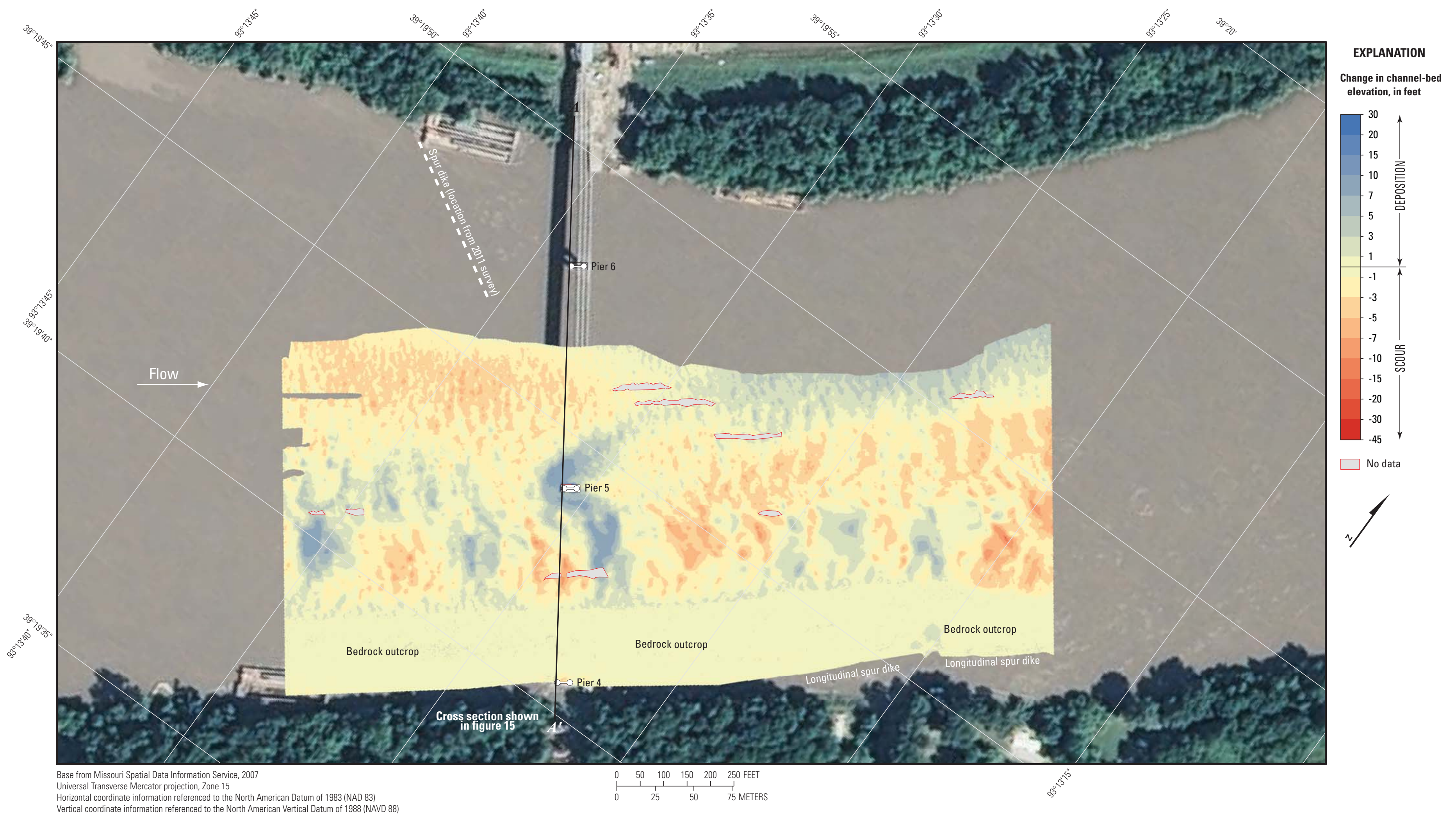

Figure 16. Difference between bathymetric surfaces created from surveys of the Missouri River channel in the vicinity of structure K0999 on State Highway 41 at Miami, Missouri, on April 25, 2013 , and July 21, 2011. 


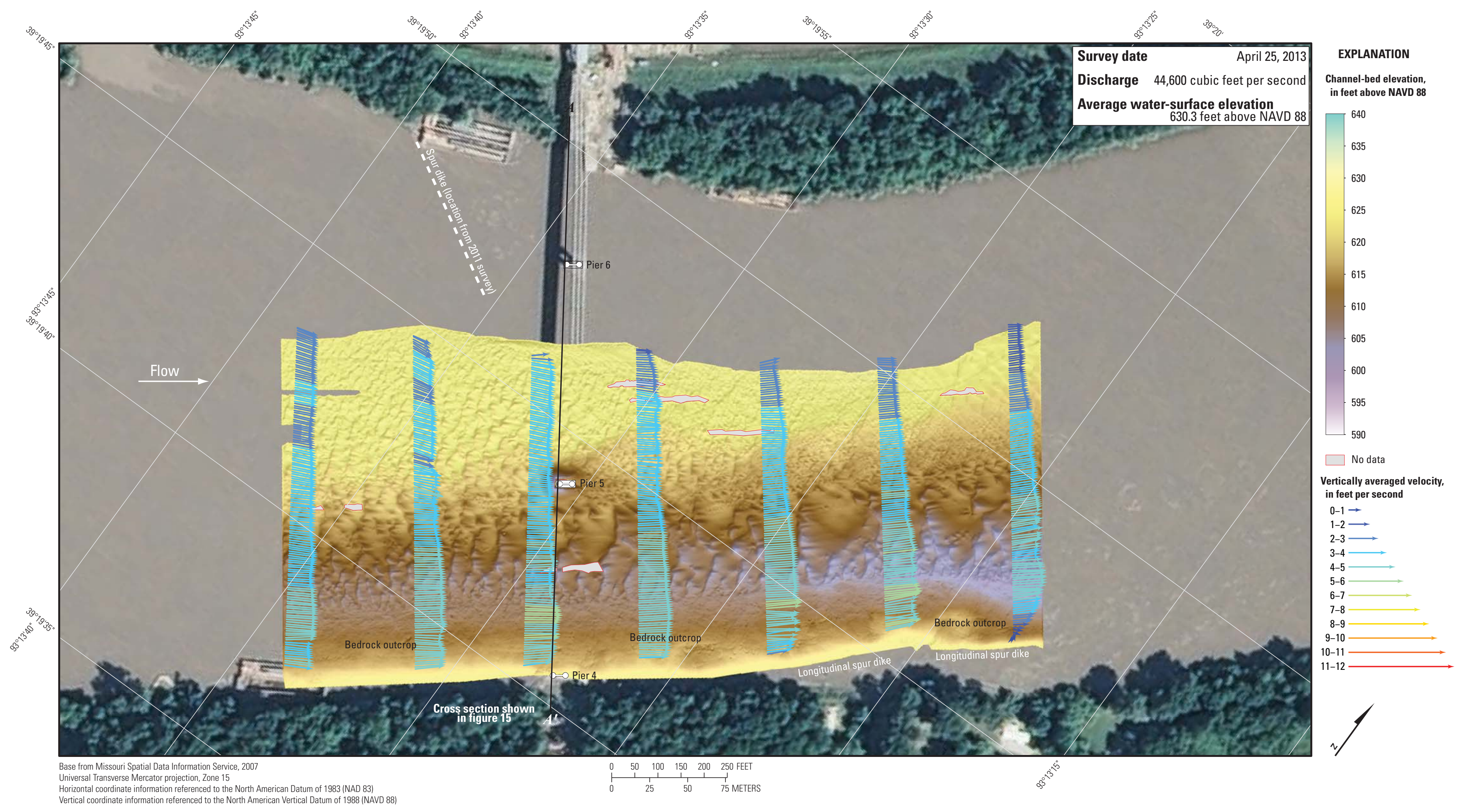

Figure 17. Bathymetry and vertically averaged velocities of the Missouri River channel in the vicinity of structure K0999 on State Highway 41 at Miami, Missouri. 


\section{Structure G0069 on State Highway 240 at Glasgow, Missouri}

Structure G0069 (site 17) on State Highway 240 crosses the Missouri River at RM 226.3 at Glasgow, Mo., southeast of Miami, and about halfway between Kansas City and St. Louis, Mo. (fig. 1; table 1). The site was surveyed on April 26, 2013, and the average water-surface elevation of the river in the survey area, determined by the RTK GNSS tide solution, was $602.0 \mathrm{ft}$ (table 2). Discharge on the Missouri River was about $71,000 \mathrm{ft}^{3} / \mathrm{s}$ during the survey (table 2). Structure G0069 is immediately downstream from a railroad bridge (fig. 18).

The survey area was about 1,640 ft long and about $900 \mathrm{ft}$ wide, extending essentially from bank to bank in the main channel (fig. 18). The upstream end of the survey area was about $590 \mathrm{ft}$ upstream from the centerline of structure G0069, and piers 2, 3, and 4 were in the water and away from the banks (fig. 18). The channel-bed elevations ranged from about 575 to $592 \mathrm{ft}$ for most of the surveyed area ( 5 to 95 percentile range of the bathymetric data), except near the piers and the banks (fig. 18; table 2). A well-defined thalweg along the upstream left (east) bank was constrained by a substantial area of exposed bedrock in the upstream reach, but widened and became less defined in the downstream reach (fig. 18). The thalweg was about 15 to $17 \mathrm{ft}$ deeper than the channel bed on the right (west) side in the upstream reach (fig. 18). Two small spur dikes, and a sunken barge observed during the 2011 survey, were present on the right bank (fig. 18). Numerous small dunes and ripples were present throughout the channel, except near the exposed bedrock (fig. 18).

No scour hole was observed near pier 2 (fig. 18), which is founded on a footing on bedrock according to bridge plans (fig. 19; table 6); however, point cloud and shaded TIN visualizations of the multibeam depth points obtained during the survey near pier 2 indicates the magnitude of the exposure of the bridge and railroad bridge piers (fig. 20). The ground line from the bathymetric survey indicated that the right side of the footing may be undermined, but the details of the footing of pier 2 in the bridge plans for structure G0069 are not sufficient to tell if it was entrenched in the bedrock in any way, particularly if the top of the bedrock was not level (figs. 18, 19). In modern construction, bridge substructural elements usually are pinned or socketed to bedrock (American Association of State Highway Transportation Officials, 2012; Brown and others, 2010), but full exposure of usually buried substructural elements warrants special consideration and observation, particularly at an older bridge such as structure G0069 (built in 1922). The footing of pier 2 does not appear to be undermined in the visualizations, although the upstream railroad bridge pier footing has apparent undermining at the upstream right corner (fig. 20).

\footnotetext{
Structure G0069 on State Highway 240 at Glasgow, Missouri.
}

Scour holes were observed near main channel piers 3 and 4. In the vicinity of main channel pier 3 (fig. 18), a substantial scour hole had a minimum channel-bed elevation of about $565 \mathrm{ft}$ (table 6), which is about $15 \mathrm{ft}$ below the average channel bed immediately upstream from the pier (figs. 18 and 19; table 6). A moderate scour hole was observed in the vicinity of main channel pier 4, having a minimum channel-bed elevation of about $579 \mathrm{ft}$ (figs. 18 and 19; table 6). Information from bridge plans indicates that piers 3 and 4 are caissons founded on bedrock, having only about $3 \mathrm{ft}$ of bed material between the bottom of the scour hole and bedrock at pier 3, and about $22 \mathrm{ft}$ of material at pier 4 (fig. 19; table 6). The scour observed near all of the highway bridge piers was substantially affected by the upstream railroad bridge piers. The surveyed bed was 5 to $10 \mathrm{ft}$ lower than the previous multibeam survey in 2011 between piers 2 and 3, except near the piers, and 5 to $10 \mathrm{ft}$ higher than the previous survey between piers 3 and 4, making it more similar to the ground line from the Level II bridge scour assessment in 2002 (fig. 19). The approximate top-ofbedrock line from bridge plans confirms that the fluvial material near the left bank has washed away, exposing the bedrock along the thalweg (fig. 19).

The difference between the surveys on April 26, 2013, and July 22, 2011 (fig. 21), indicates substantial deposition of as much as $20 \mathrm{ft}$ has occurred particularly in the thalweg along the downstream left bank. Additional moderate deposition of as much as $10 \mathrm{ft}$ has occurred along the right side of the upstream channel, with moderate scour in the downstream middle channel (fig. 21). The mean difference between the July 2011 and April 2013 bathymetric surfaces $(0.94 \mathrm{ft}$; table 7) indicates minor deposition overall, as evident in the difference map (fig. 21). The series of large dunes evident in the July 2011 survey is indicated by a series of alternating scour and deposition patches along the middle of the upstream channel (fig. 21). As much as $15 \mathrm{ft}$ of scour was observed downstream from the downstream spur dike (fig. 21). A minimal amount of deposition was observed on the bedrock outcrop and stone revetment along the left bank (fig. 21). In the difference map, the appearance of substantial deposition or scour near the piers results from minor horizontal positional variances between the surveys (fig. 21).

The vertically averaged velocity vectors indicate slight to moderate turbulence throughout most of the channel, with velocities ranging from about 3 to $7 \mathrm{ft} / \mathrm{s}$ (fig. 22). Velocities were greater in the thalweg and lower in the shallow area on the right (west) side of the upstream channel, whereas the velocities were more uniform in the downstream channel where the thalweg was less defined (fig. 22). Turbulence, caused by local disturbances from the piers and spur dikes in the reach, was observed at various places in the channel (fig. 22). A substantial debris raft on the upstream nose of the railroad bridge pier upstream from pier 2 caused the velocity vectors to flare around that pier (fig. 22). 


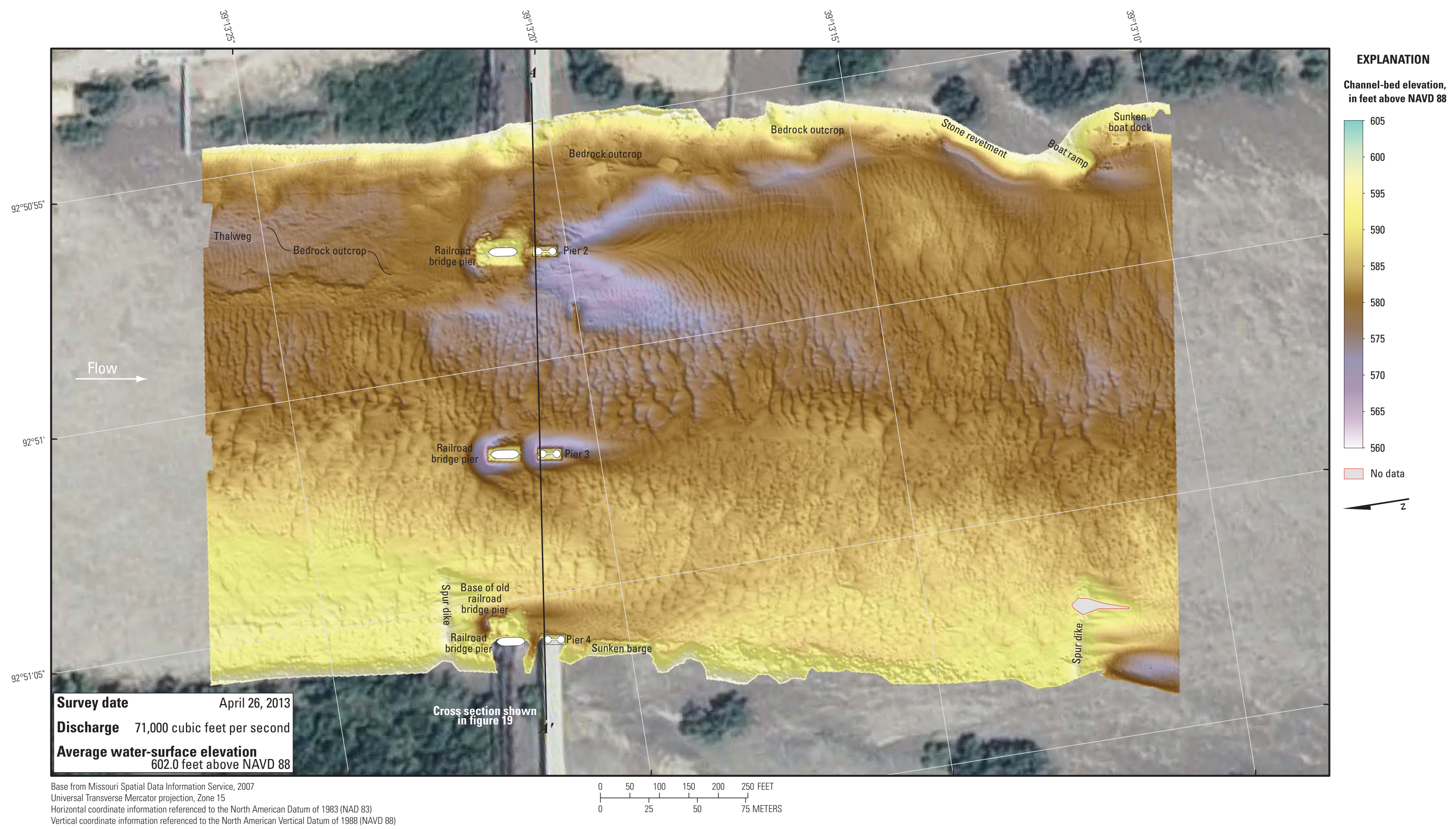

Figure 18. Bathymetric survey of the Missouri River channel in the vicinity of structure G0069 on State Highway 240 at Glasgow, Missouri. 


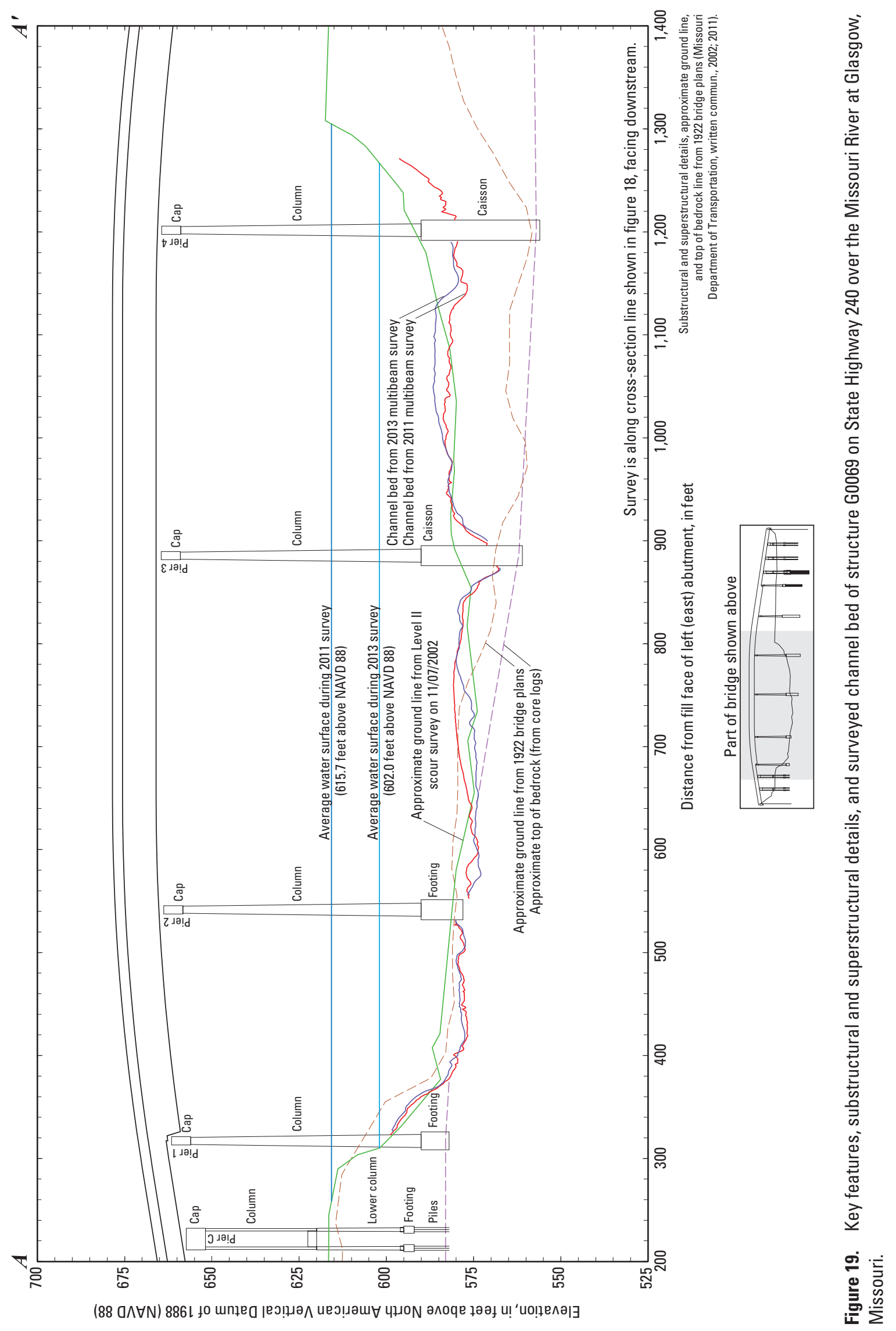



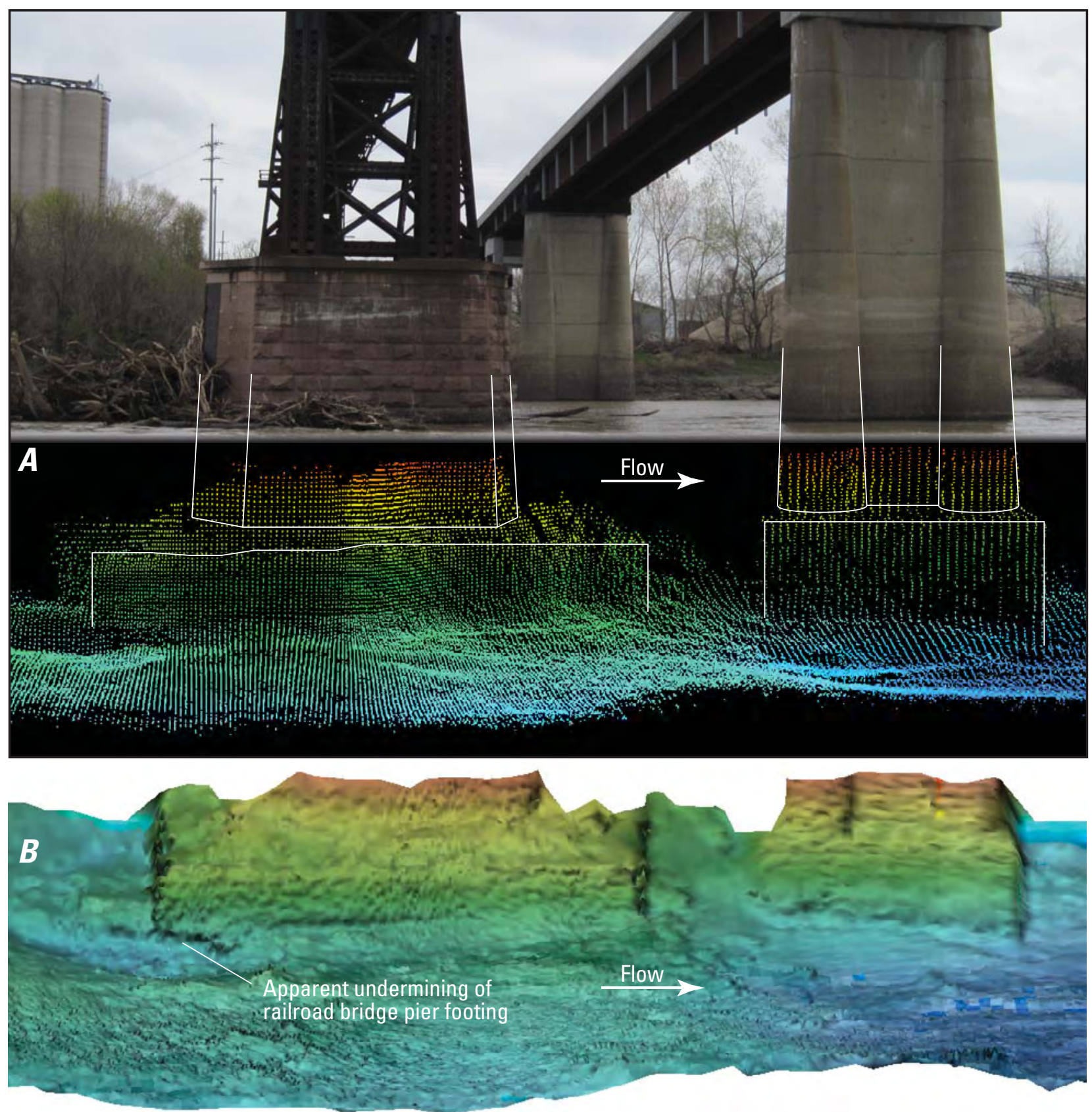

EXPLANATION

Elevation of point, in feet

above the North American

Vertical Datum of 1988

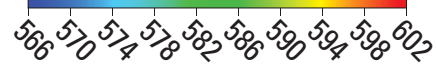

Figure 20. Visualizations of the channel bed and right (west) side of main channel pier 2 of structure $\mathrm{G} 0069$ on State Highway 240 and the upstream railroad bridge pier over the Missouri River at Glasgow, Missouri, as a $A$, point cloud, and $B$, shaded triangulated irregular network (TIN). 


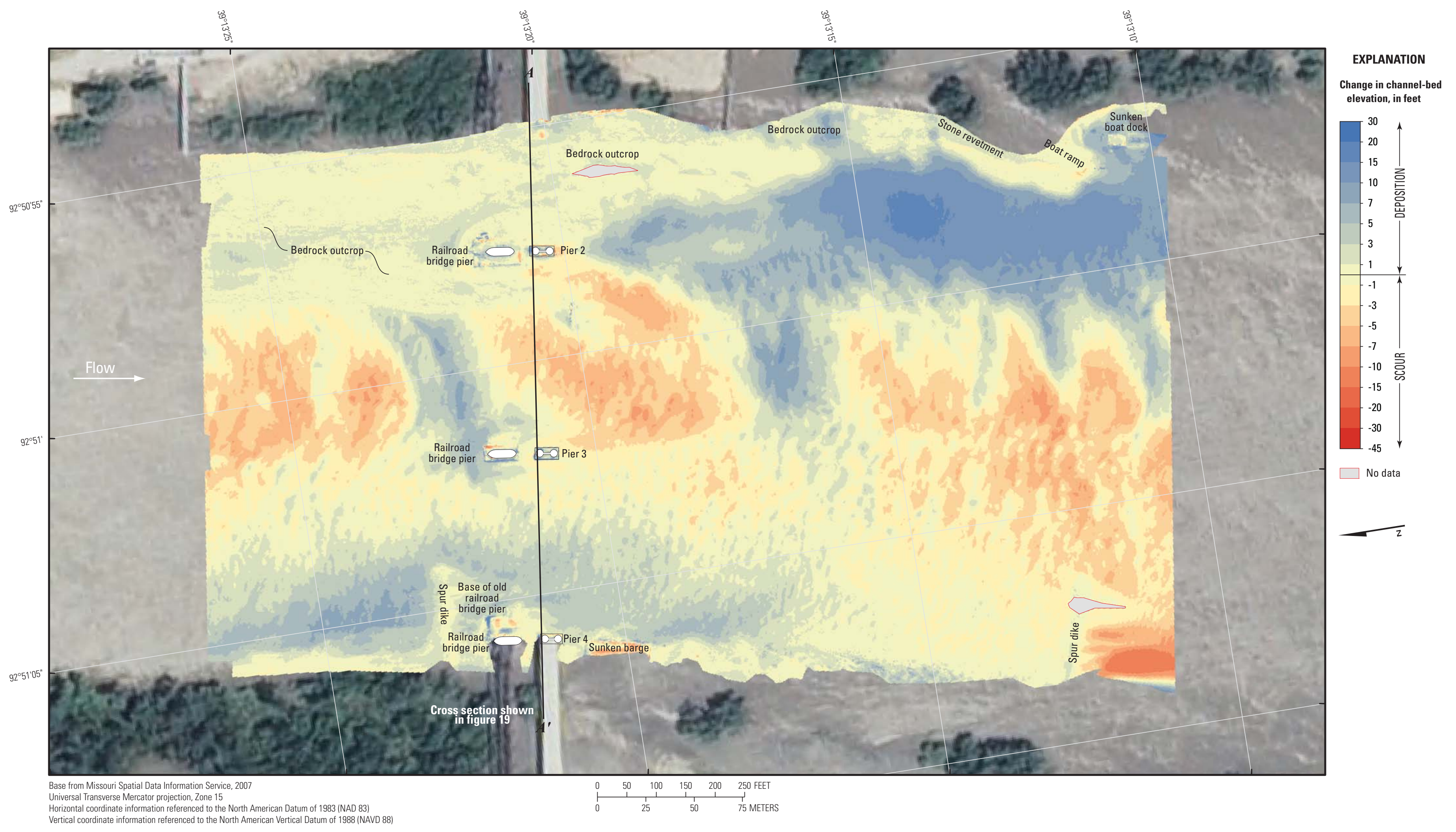

Figure 21. Difference between bathymetric surfaces created from surveys of the Missouri River channel in the vicinity of structure G0069 on State Highway 240 at Glasgow, Missouri, on April 26, 2013, and July 22, 2011. 


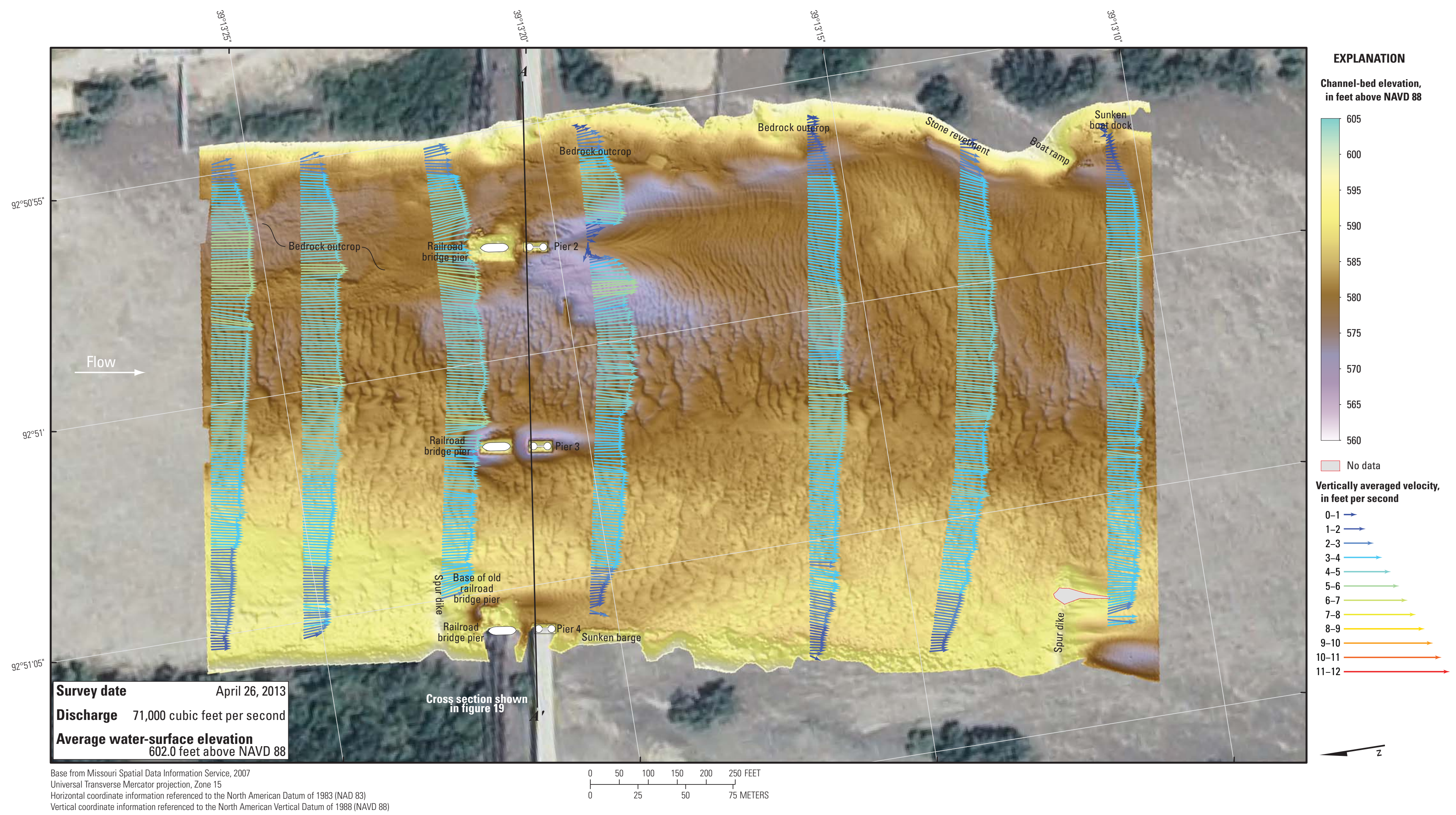

Figure 22. Bathymetry and vertically averaged velocities of the Missouri River channel in the vicinity of structure G0069 on State Highway 240 at Glasgow, Missouri. 


\section{Structure A4574 on State Highway 5 at Boonville, Missouri}

Structure A4574 (site 18) on State Highway 5 crosses the Missouri River at RM 196.6 at Boonville, Mo., south of Glasgow and about halfway between Kansas City and St. Louis, Mo. (fig. 1; table 1). The site was surveyed on April 29, 2013, and the average water-surface elevation of the river in the survey area, determined by the RTK GNSS tide solution, was $576.0 \mathrm{ft}$ (table 2). Discharge on the Missouri River was about 58,700 $\mathrm{ft}^{3} / \mathrm{s}$ during the survey (table 2).

The survey area was about 1,640 ft long and about $1,150 \mathrm{ft}$ wide, extending from the inside of the longitudinal spur dikes and stone revetment on the left (north) bank to a shallow area along the right (south) bank in the main channel (fig. 23). The upstream end of the survey area was about $620 \mathrm{ft}$ upstream from the centerline of structure A4574 (fig. 23), and piers 5 through 8 were in the water, although piers 5 and 8 were on the extreme edges of the surveyed area (fig. 23). The channel-bed elevations ranged from about 554 to $568 \mathrm{ft}$ for most of the surveyed area ( 5 to 95 percentile range of the bathymetric data), except in the channel thalweg along the left bank where the local minimum channel-bed elevation was $548 \mathrm{ft}$ (fig. 23; table 2). Numerous small dunes and ripples were present throughout the channel (fig. 23).

Minor scour holes were observed near the central main channel piers 6 and 7 . In the vicinity of main channel pier 7 (fig. 23), the scour hole had a minimum channel-bed elevation of about $556 \mathrm{ft}$ (table 6), about $23 \mathrm{ft}$ above the elevation of the bottom of the pier seal course of $533.00 \mathrm{ft}$ (fig. 24; table 6). The minor scour hole near pier 6 (fig. 23) had a minimum channel-bed elevation of about $563 \mathrm{ft}$ (table 6). Both scour holes were difficult to discern from nearby dunes and ripples (figs. 23, 24). Information from bridge plans indicates that pier 7 is founded on shafts drilled $39 \mathrm{ft}$ into bedrock, having about $43 \mathrm{ft}$ of bed material between the bottom of the scour hole and bedrock (fig. 24; table 6). Pier 6 is founded on a footing on bedrock, having about $12 \mathrm{ft}$ of bed material between the bottom of the scour hole and bedrock (fig. 24; table 6). The surveyed bed generally was about $5 \mathrm{ft}$ lower than the previous multibeam survey in 2011 between the left bank and the middle of the channel between piers 6 and 7, and about 5 to
$10 \mathrm{ft}$ higher than the previous multibeam survey from the middle of the channel to the right bank (fig. 24).

Main channel piers 5 and 8 were along the edges of the surveyed area. Pier 8 is immediately downstream from a longitudinal spur dike and appears to be embedded in the stone revetment along the left bank (fig. 23). A scour hole near the downstream toe of the spur dike reached a minimum channel-bed elevation of about $548 \mathrm{ft}$ (table 6), which is about $21 \mathrm{ft}$ above the elevation of the bottom of the pier seal course of $527.00 \mathrm{ft}$ (fig. 24; table 6). The minimum elevation surveyed near pier 5 was about $564 \mathrm{ft}$ (figs. 23 and 24), which is about $4 \mathrm{ft}$ above the elevation of bedrock near the pier; pier 5 is founded on a footing on bedrock according to bridge plans (fig. 24; table 6). In modern construction, bridge substructural elements usually are pinned or socketed to bedrock (American Association of State Highway Transportation Officials, 2012; Brown and others, 2010), but full exposure of usually buried substructural elements warrants special consideration and observation.

The difference between the surveys on April 29, 2013, and July 25, 2011 (fig. 25), indicates a rough balance between scour and deposition throughout the channel. Moderate scour of as much as $15 \mathrm{ft}$ has occurred downstream from a spur dike on the right bank just upstream from the surveyed reach and near the upstream end of the longitudinal spur dike on the upstream left side of the channel, whereas moderate deposition of as much as $7 \mathrm{ft}$ has occurred throughout the right side of the channel (fig. 25). The mean difference between the July 2011 and April 2013 bathymetric surfaces (0.07 ft; table 7) indicates essentially zero net change overall, as evident in the difference map (fig. 25). The series of large dunes evident in the July 2011 survey is indicated by a series of alternating scour and deposition patches along the left side of the channel in the thalweg (fig. 25). A minimal amount of deposition was observed on the longitudinal spur dike and stone revetment along the left bank (fig. 25).

The vertically averaged velocity vectors indicate mostly uniform flow throughout most of the channel, ranging from about 2 to $6 \mathrm{ft} / \mathrm{s}$ (fig. 26). Flow reversal and minor turbulence was observed on the right side of the channel downstream from the spur dike just upstream from the reach (fig. 26). The bridge piers were aligned with flow, causing little to no turbulence downstream (fig. 26) despite a reduction in velocity downstream from pier 7 (fig. 26).

Structure A4574 on State Highway 5 at Boonville, Missouri. 


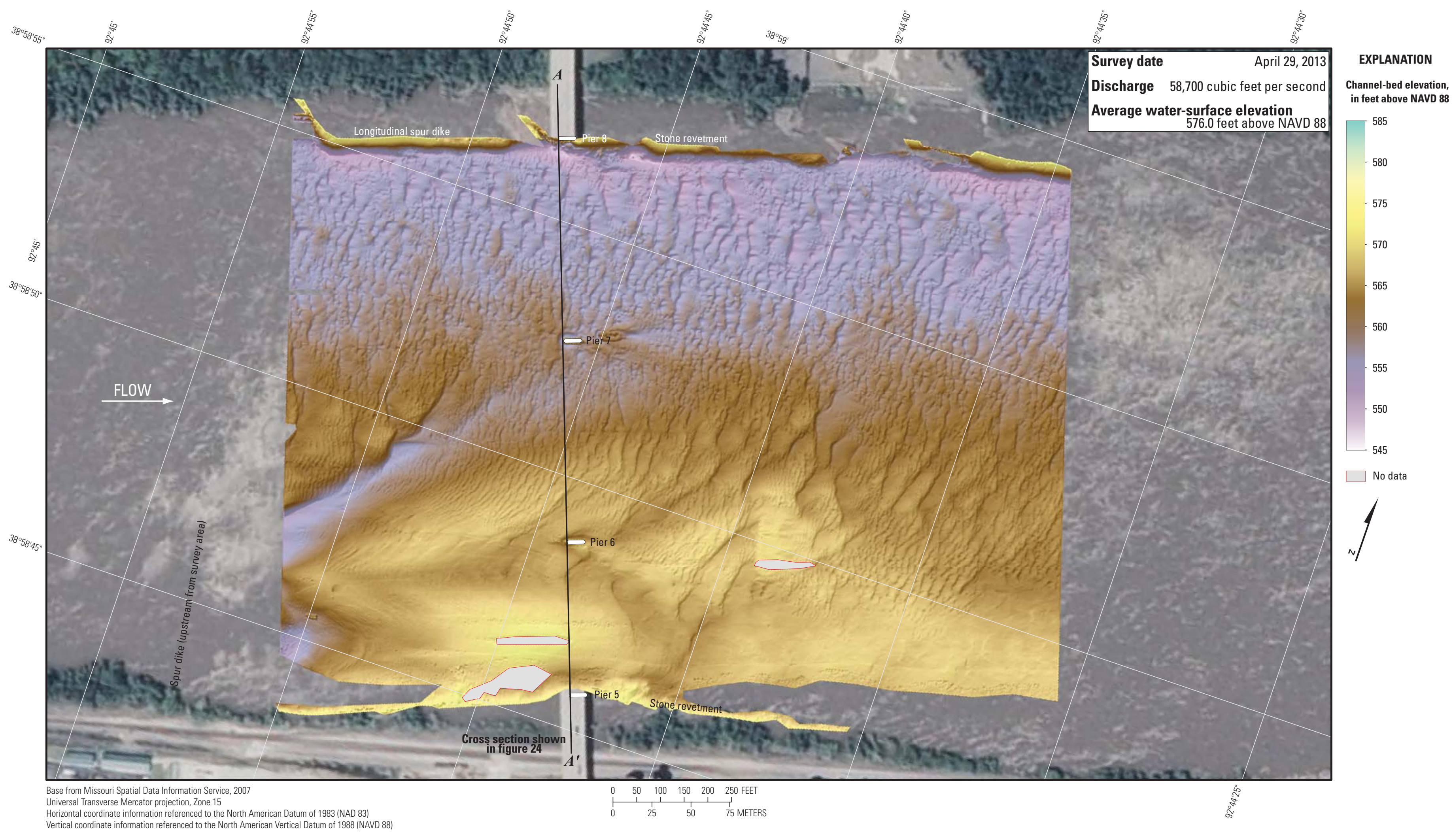

Figure 23. Bathymetric survey of the Missouri River channel in the vicinity of structure A4574 on State Highway 5 at Boonville, Missouri. 


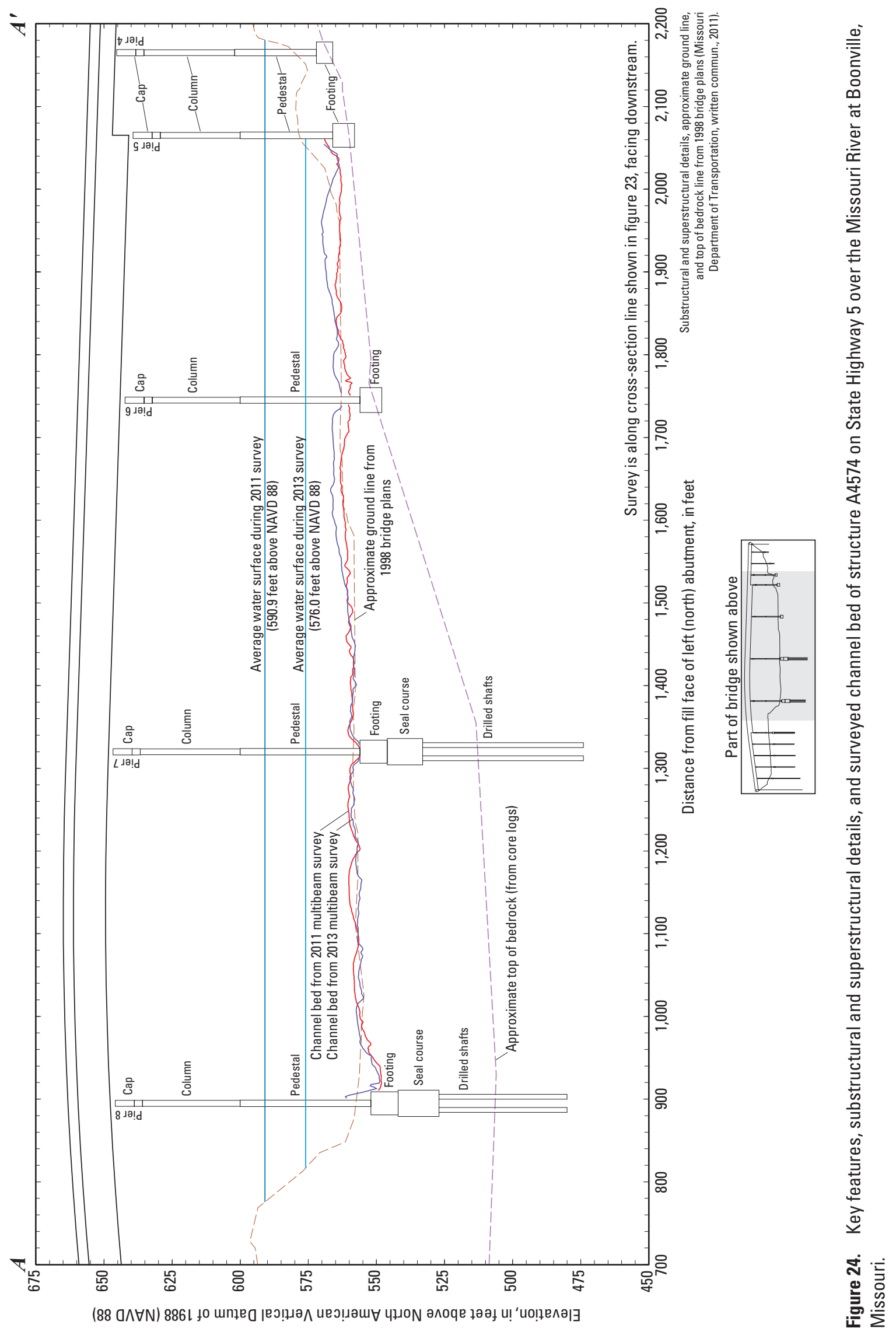




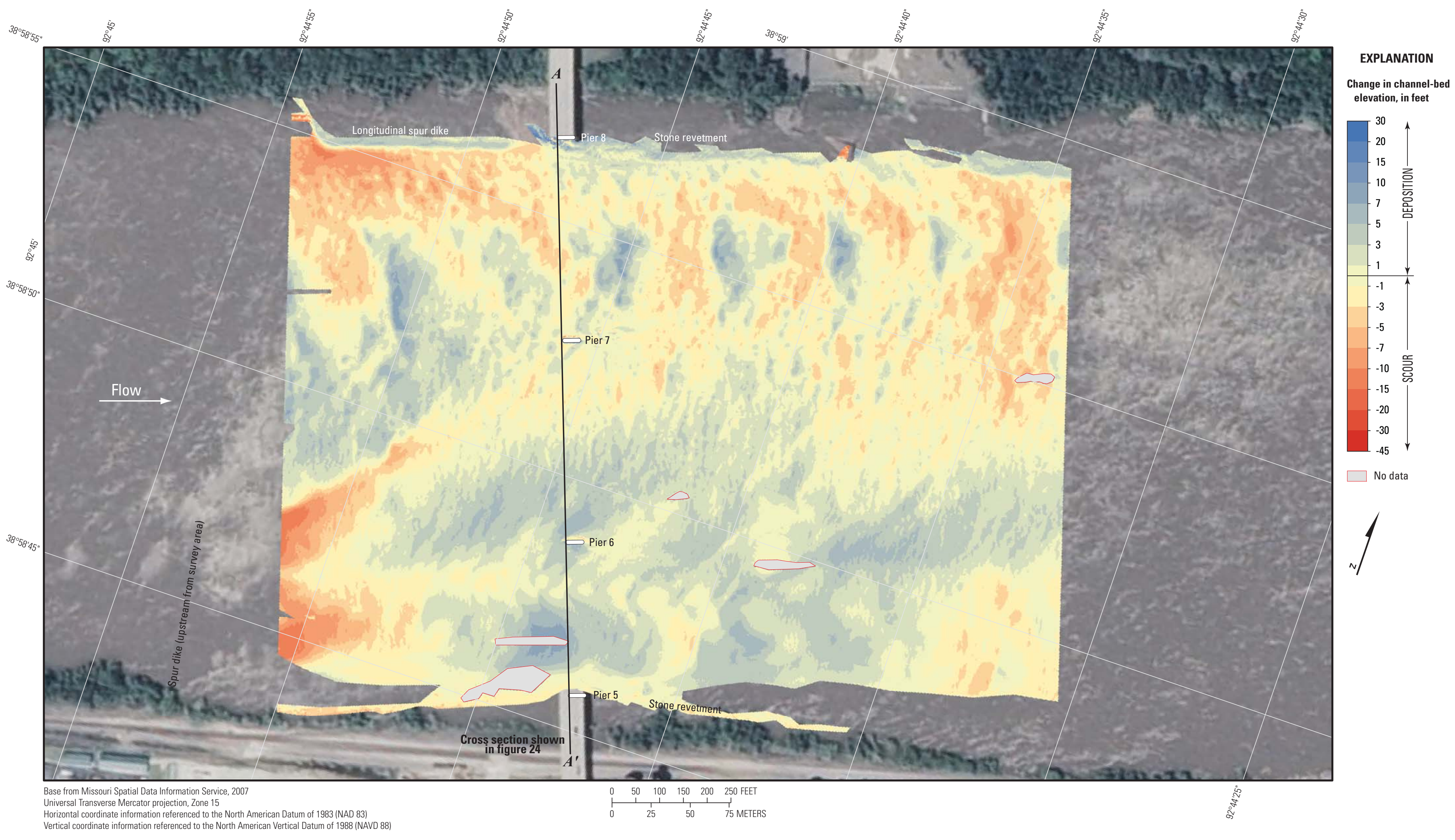

Figure 25. Difference between bathymetric surfaces created from surveys of the Missouri River channel in the vicinity of structure A4574 on State Highway 5 at Boonville, Missouri, on April 29, 2013, and July 25, 2011. 


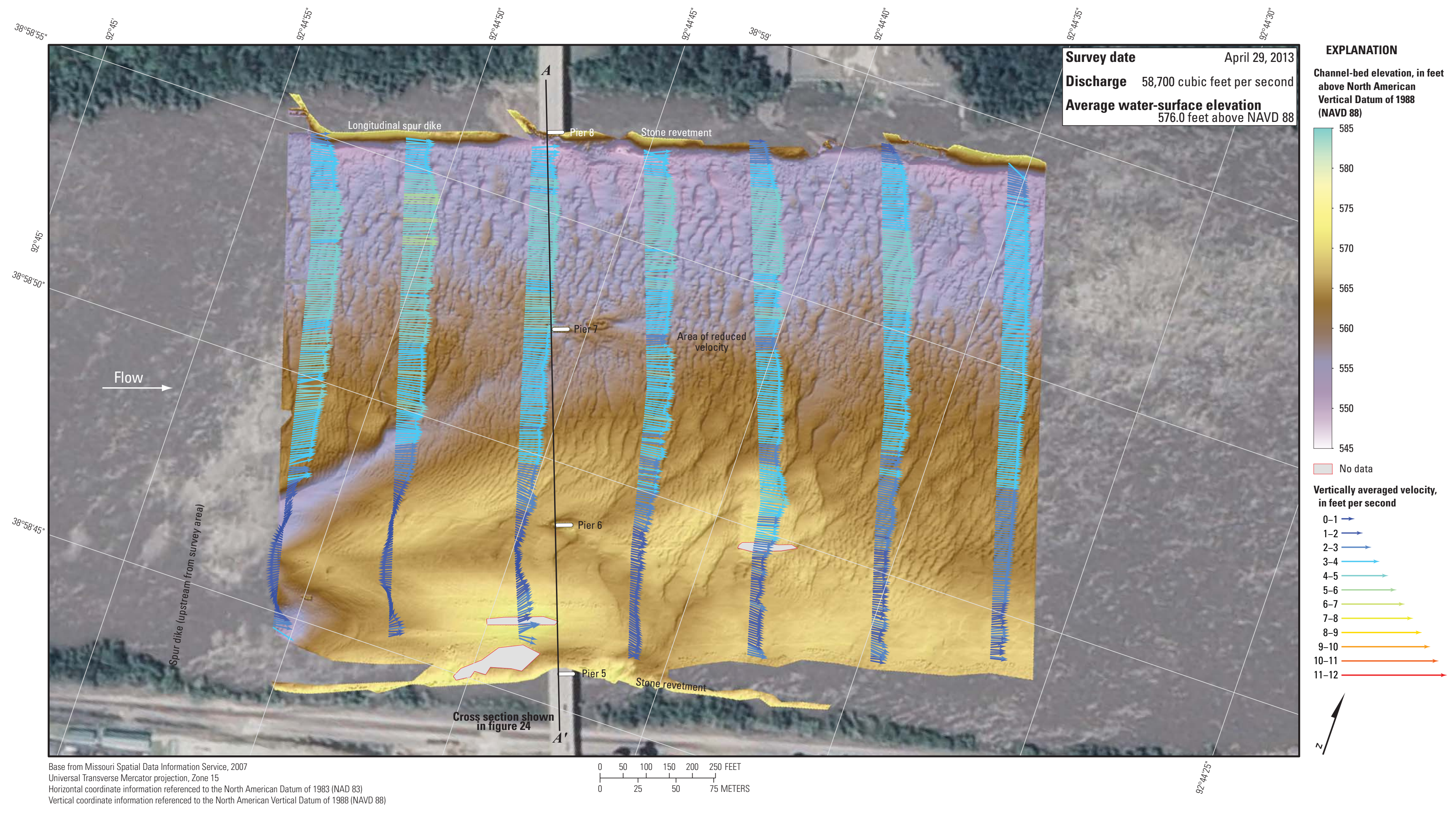

Figure 26. Bathymetry and vertically averaged velocities of the Missouri River channel in the vicinity of structure A4574 on State Highway 5 at Boonville, Missouri. 


\section{Structure L0962 on Interstate 70 near Rocheport, Missouri}

Structure L0962 (site 19) on Interstate 70 crosses the Missouri River at RM 185.1 near Rocheport, Mo., east of Boonville and west of St. Louis, Mo. (fig. 1; table 1). The site was surveyed on April 29, 2013, and the average water-surface elevation of the river in the survey area, determined by the RTK GNSS tide solution, was $566.5 \mathrm{ft}$ (table 2). Discharge on the Missouri River was about $63,400 \mathrm{ft}^{3} / \mathrm{s}$ during the survey (table 2).

The survey area was about 1,640 ft long and about $935 \mathrm{ft}$ wide, generally extending from the longitudinal spur dikes on the left (northeast) bank to the right (southwest) bank in the main channel (fig. 27). The upstream end of the survey area was about $580 \mathrm{ft}$ upstream from the centerline of structure L0962 (fig. 27), and piers 14 and 15 were in the water. The channel-bed elevations ranged from about 538 to $556 \mathrm{ft}$ for most of the surveyed area ( 5 to 95 percentile range of the bathymetric data). A poorly defined thalweg was present along the left bank, and a series of medium dunes were present in the middle of the channel, with numerous small dunes and ripples present throughout the rest of the channel (fig. 27). The part of the channel bed between the longitudinal spur dikes on the upstream left bank was surveyed using the tilted head configuration of the MBES (fig. 27; table 4). The spur dikes prevented surveying to the left of pier 15 or near bent 16 (fig. 27).

In the vicinity of main channel pier 14 (fig. 27), a substantial scour hole had a minimum channel-bed elevation of about $530 \mathrm{ft}$ (table 6), which is about $17 \mathrm{ft}$ below the average channel elevation upstream from the bridge (fig. 28; table 2). Information from bridge plans indicates that pier 14 is founded on a caisson on bedrock, having about $32 \mathrm{ft}$ of bed material between the bottom of the scour hole and bedrock (fig. 28; table 6). Pier 15 is embedded in the longitudinal spur dike, and the minimum channel elevation at the toe of the dike was about $535 \mathrm{ft}$ (figs. 27 and 28; table 6). Pier 15 also is founded on a caisson on bedrock, having about $16 \mathrm{ft}$ of material between the minimum channel elevation and bedrock (fig. 28; table 6); however, the rock of the spur dike will limit or prevent a local scour hole near pier 15 . The surveyed bed generally was higher than the previous multibeam survey in 2011, with 15 to $20 \mathrm{ft}$ of deposition in the middle between piers 14 and 15 , and about 5 to $10 \mathrm{ft}$ of deposition between pier 14 and the right bank (fig. 28).

The difference between the surveys on April 29, 2013, and July 26, 2011 (fig. 29), indicates a rough balance between scour and deposition throughout the channel. Moderate to substantial deposition of as much as $15 \mathrm{ft}$ has occurred between and along the toe of the longitudinal spur dikes on the left bank, and downstream of the spur dike just upstream from the surveyed reach on the right side of the channel, whereas moderate to substantial scour of as much as $15 \mathrm{ft}$ has occurred in the upstream middle part of the channel and near the downstream spur dike (fig. 29). The mean difference between the July 2011 and April 2013 bathymetric surfaces (0.32 ft; table 7) indicates minor deposition overall. The series of very large dunes evident in the July 2011 survey is indicated as a series of alternating scour and deposition patches along the left side of the channel in the thalweg (fig. 29).

The vertically averaged velocity vectors indicate mostly uniform flow in the thalweg, with areas of turbulence along the right bank (fig. 30). Velocities ranged from about 3 to $6 \mathrm{ft} / \mathrm{s}$ for most of the channel (fig. 30), with locally lower velocities and flow reversal along the right bank and between the longitudinal spur dikes on the upstream left bank (fig. 30). Pier 14 was mostly aligned with flow, causing minimal turbulence downstream (fig. 30); however, flow approached pier 14 from the left, causing an asymmetric scour hole that is longer and slightly deeper on the left side (fig. 30).

Structure L0962 on Interstate 70 near Rocheport, Missouri. 


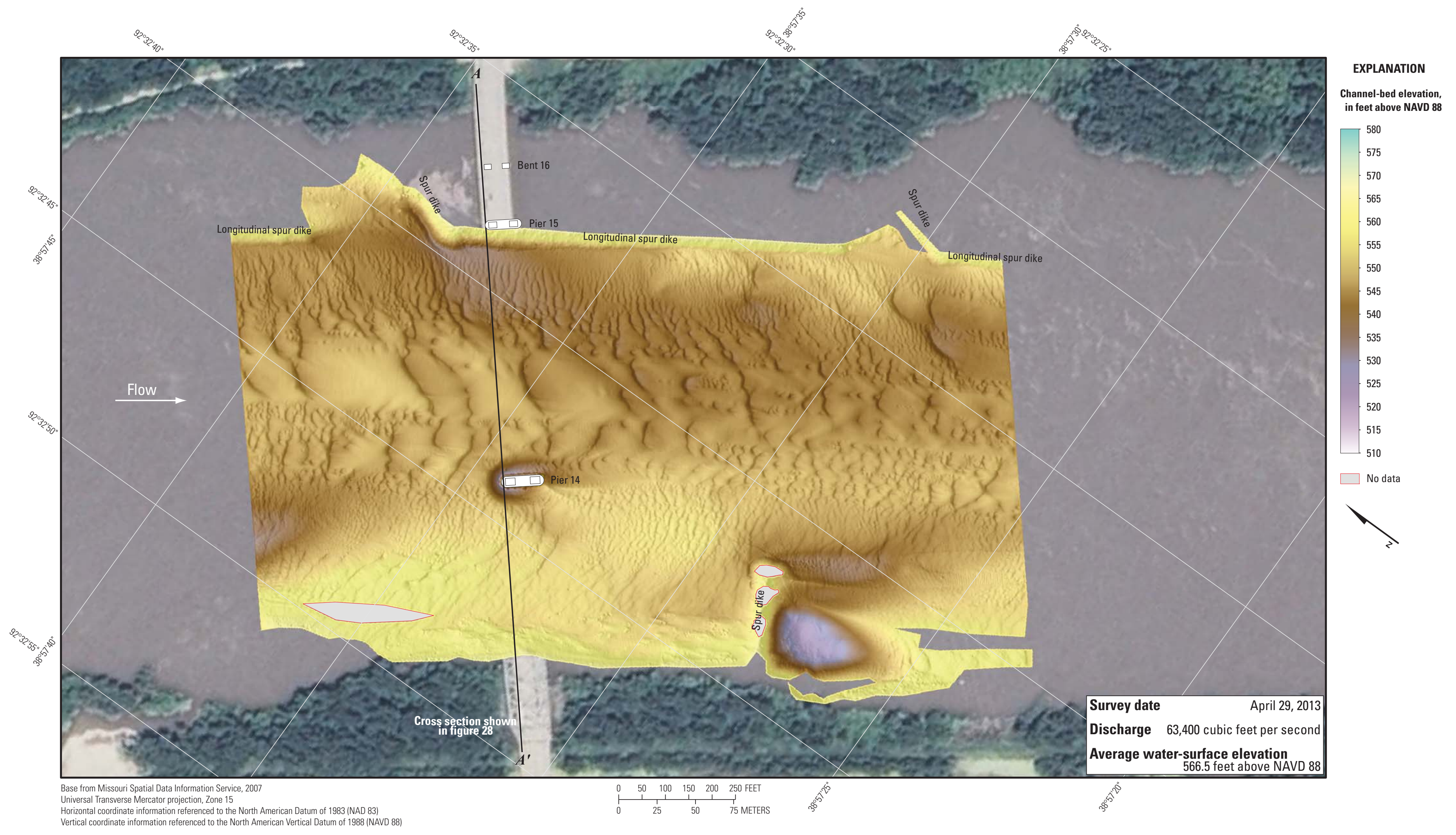

Figure 27. Bathymetric survey of the Missouri River channel in the vicinity of structure L0962 on Interstate 70 near Rocheport, Missouri. 


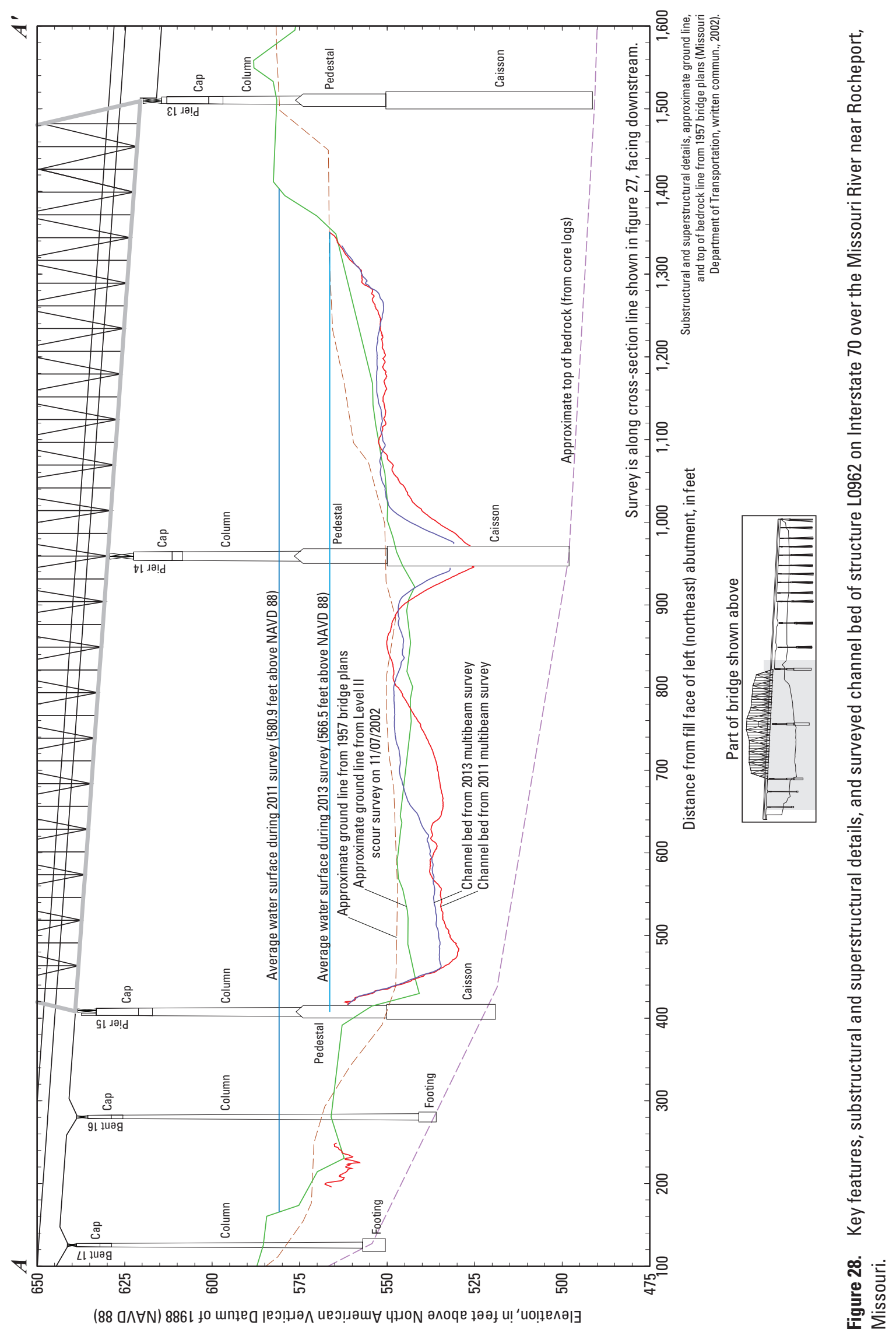




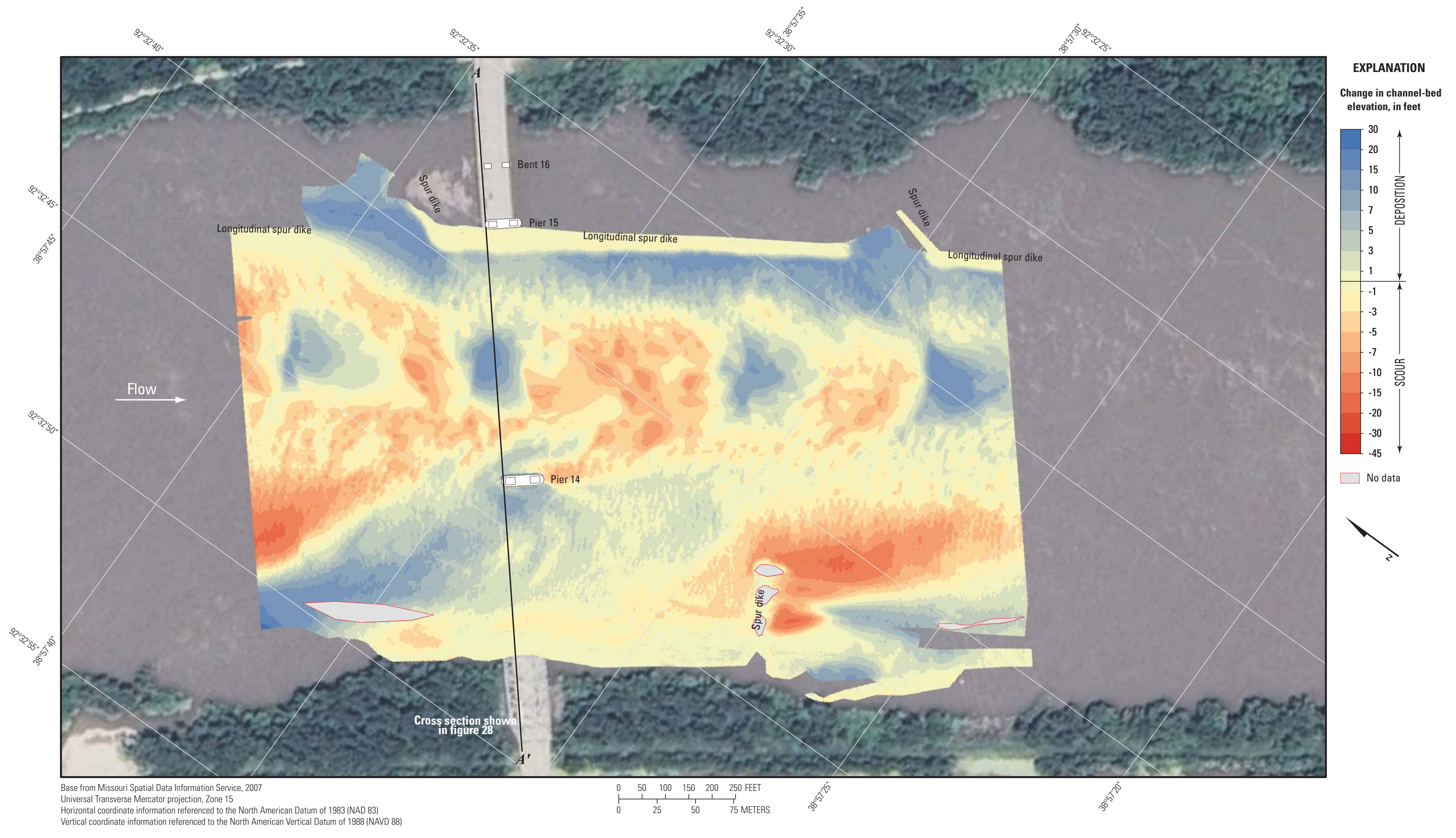

Figure 29. Difference between bathymetric surfaces created from surveys of the Missouri River channel in the vicinity of structure L0962 on Interstate 70 near Rocheport, Missouri, on April 29, 2013, and July 26, 2011. 


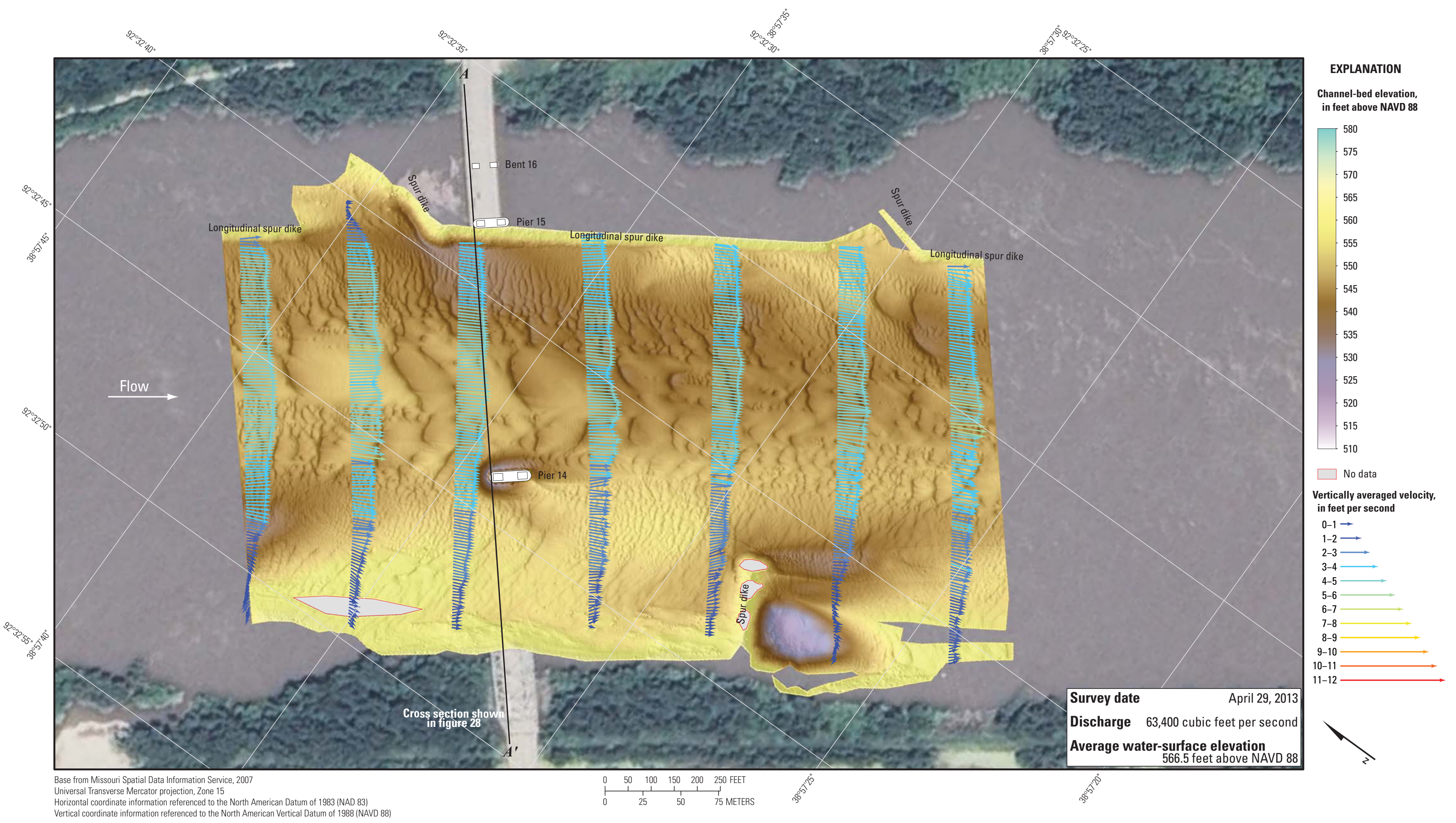

Figure 30. Bathymetry and vertically averaged velocities of the Missouri River channel in the vicinity of structure L0962 on Interstate 70 near Rocheport, Missouri. 


\section{Structures L0550 and A4497 on U.S. Highway 54 at Jefferson City, Missouri}

Structures L0550 and A4497 (site 20) are dual bridges on U.S. Highway 54 crossing the Missouri River at RM 143.9 at Jefferson City, Mo., southeast of Rocheport and west of St. Louis, Mo. (fig. 1; table 1). The site was surveyed on April 30, 2013, and the average water-surface elevation of the river in the survey area, determined by the RTK GNSS tide solution, was $530.3 \mathrm{ft}$ (table 2). Discharge on the Missouri River was about $62,500 \mathrm{ft}^{3} / \mathrm{s}$ during the survey (table 2). This site has been the subject of several multibeam surveys (Huizinga, 2012) that provide bathymetry at a variety of flow conditions for comparison.

The survey area was about 1,640 ft long and about $970 \mathrm{ft}$ wide from bank to bank in the main channel (fig. 31). The upstream end of the survey area was about $630 \mathrm{ft}$ upstream from the centerline between structures L0550 and A4497 (fig. 31), and only pier 4 of each structure was in the water and away from the banks. The channel-bed elevations ranged from about 502 to $521 \mathrm{ft}$ for most of the surveyed area (5 to 95 percentile range of the bathymetric data), except near the piers (fig. 31). Numerous small dunes and ripples were present throughout the channel (fig. 31).

A moderate to substantial scour hole was observed near the main channel piers. In the vicinity of pier 4 of upstream structure L0550 (fig. 31), the scour hole had a minimum channel-bed elevation of about $483 \mathrm{ft}$ (table 6), which is about $21 \mathrm{ft}$ below the average channel elevation upstream from the bridge (fig. 32; table 6). Information from bridge plans indicates that pier 4 of upstream structure L0550 is founded on a caisson on bedrock, having about $24 \mathrm{ft}$ of bed material between the bottom of the scour hole and bedrock (fig. 32; table 6). The scour hole near pier 4 of downstream structure A4497 was substantially affected by the upstream pier, having a minimum channel-bed elevation of about $483 \mathrm{ft}$ (table 6), which is about $11 \mathrm{ft}$ below the elevation of the bottom of the pier seal course of $493.50 \mathrm{ft}$ (figs. 33 and 34; table 6). Pier 4 of structure A4497 is founded on shafts drilled $11 \mathrm{ft}$ into bedrock, having about $24 \mathrm{ft}$ of bed material between the bottom of the surveyed scour hole and bedrock (fig. 33; table 6). The surveyed bed generally was similar to the multibeam survey from March 2011 and higher than the multibeam survey in July 2011, with 5 to $10 \mathrm{ft}$ of deposition compared to the July 2011 survey, except near the piers (figs. 32 and 33). The scour hole at downstream structure A4497 appeared to be relatively consistent in size and depth between the various surveys (fig. 33); however, the scour hole at upstream structure L0550 was substantially deeper in the July 2011 survey, and was substantially shallower in this mostrecent survey than the other surveys by 5 to $10 \mathrm{ft}$ (fig. 32). The drilled shaft under the seal course of the downstream pier can clearly be seen in the TIN visualization (fig. 34).

The real-time scour monitors at this site detailed by Huizinga (2012) have been collecting data almost continuously since they were installed in November 2010 (fig. 35). Although the monitor attached to pier 4 of upstream structure L0550 was not collecting consistent data during any of the

Structures L0550 and A4497 on U.S. Highway 54 at Jefferson City, Missouri. 
surveys using the MBMS, the monitor on pier 4 of downstream structure A4497 functioned flawlessly except when the water-surface elevation dropped below the transducer (approximately $525 \mathrm{ft}$; fig. 35). During the April 2013 survey, the monitor sensed an average channel-bed elevation of $486.5 \mathrm{ft}$, which is about $1.5 \mathrm{ft}$ higher than the surveyed bed elevation of $485 \mathrm{ft}$ at the nose of the pier (table 6). Huizinga (2012) indicated the channel-bed elevation recorded from the downstream monitor was about $3 \mathrm{ft}$ higher than the elevation from near the center of the nose of the downstream pier during the March and July 2011 surveys. Several potential sources of the difference were discussed, and the most probable was that the monitor transducer was tilted forward from vertical to allow the beam to clear the top of the footing and seal course [see fig. 92 in Huizinga (2012)], resulting in uncertainty about the exact location of the transducer beam in the scour hole. In any case, the differences between the MBMS and monitor elevations are deemed to be reasonable, and the monitors have functioned as designed with a tolerance of plus or minus $3 \mathrm{ft}$. The TIN visualization shows the point of minimum elevation near the downstream pier actually is under the seal course, at an elevation of about $483 \mathrm{ft}$ (fig. 34; table 6). Both monitors have documented scour holes forming during flood events, and filling during flood recessions and low-flow periods (fig. 35). Often the scour response is rapid and substantial (the downstream monitor routinely indicates in excess of $10 \mathrm{ft}$ of scour) despite the size of the flood event (fig. 35).

The difference between the surveys on April 30, 2013, and the summer flooding of July 27, 2011 (fig. 36A), indicates substantial deposition of as much as $15 \mathrm{ft}$ has occurred throughout the channel, and deposition of as much as $30 \mathrm{ft}$ near the upstream pier. Scour of as much as $7 \mathrm{ft}$ has occurred at the upstream fringe of the reach, downstream from the spur dike and the boat ramp on the left (north) bank, and around the submerged object near the piers (fig. 36A). The mean difference between the July 2011 and April 2013 bathymetric surfaces ( $3.60 \mathrm{ft}$; table 7 ) indicates moderate to substantial deposition overall, as evident in the difference map (fig. 36A).
The difference between the surveys on April 30, 2013, and during the spring flooding on March 1, 2011 (fig. 36B), indicates an apparent balance between areas of mild to moderate scour and mild to moderate deposition, whereas the difference between the surveys on April 30, 2013, and January 26, 2010 (fig. 36C), indicates more scour overall, with strips of mild to moderate deposition near and downstream from the piers and along the left bank. The mean difference between the March 2011 and April 2013 bathymetric surfaces $(0.21 \mathrm{ft}$; table 7) indicates minor deposition overall, despite the substantially different flow rates $\left(82,500 \mathrm{ft}^{3} / \mathrm{s}\right.$ difference; table 7$)$. The mean difference between the January 2010 and April 2013 bathymetric surfaces $(-1.23 \mathrm{ft}$; table 7$)$ indicates moderate scour overall, and is more consistent with the higher flow rate observed in $2010\left(92,500 \mathrm{ft}^{3} / \mathrm{s}\right.$ difference; table 7). In all of the difference maps (fig. 36), the appearance of substantial deposition or scour near the piers results from minor horizontal positional variances between the surveys; however, there was as much as $30 \mathrm{ft}$ of deposition near the upstream pier of upstream structure L0550 between the July 2011 and April 2013 surveys (fig. 36A), and as much as $20 \mathrm{ft}$ of deposition between the March 2011 and January 2010 surveys, and the April 2013 survey (figs. 36B and 36C). A pocket of entrained air or dense suspended sediment was observed on the left side of the upstream end of the upstream pier in the January 2010 and March 2011 surveys (likely caused by vortex action from the blunt nose of the pier). This pocket or air or sediment appears as a pocket of scour in the difference maps (figs. $36 B$ and 36C).

The vertically averaged velocity vectors indicate uniform flow throughout most of the reach, with small areas of turbulence, particularly along the banks and near the spur dike on the upstream left bank (fig. 37). Velocities ranged from about 3 to $6 \mathrm{ft} / \mathrm{s}$ for most of the channel (fig. 37), except in the vicinity of the spur dike, where low velocities and flow reversals were observed. The piers of both bridges generally were aligned with flow, but minor turbulence was observed downstream (fig. 37). 


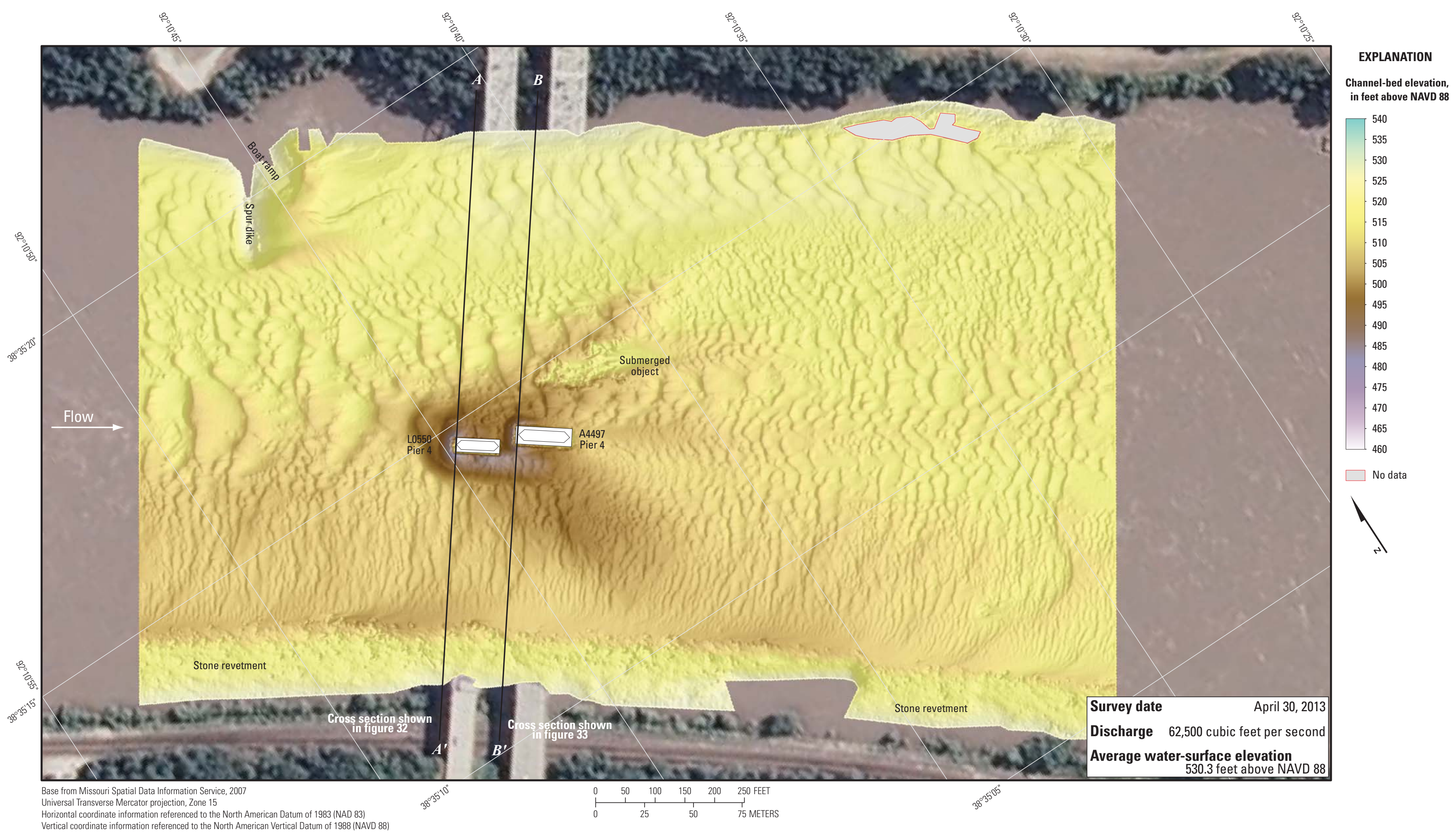

Figure 31. Bathymetric survey of the Missouri River channel in the vicinity of structures L0550 and A4497 on U.S. Highway 54 at Jefferson City, Missouri. 


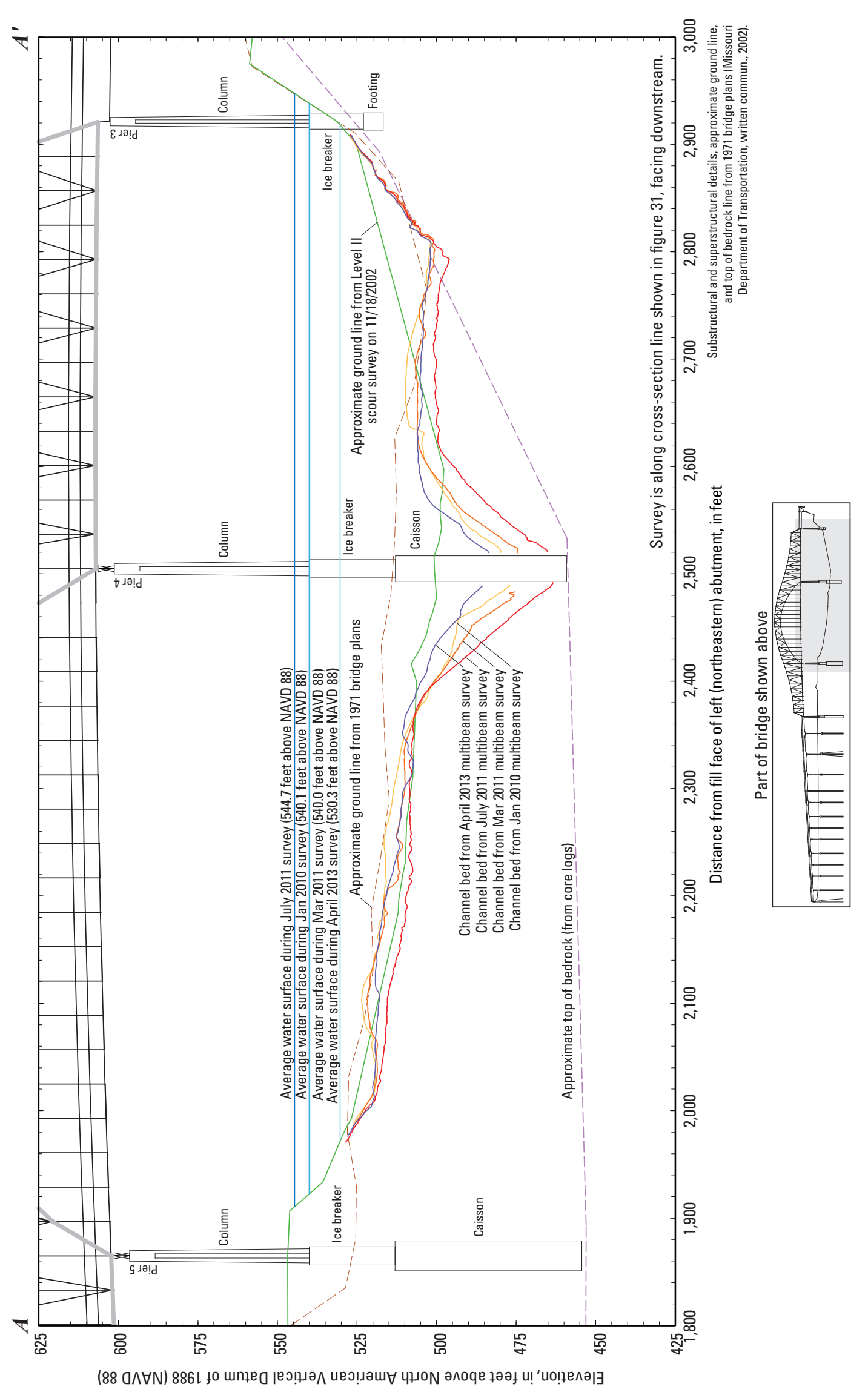

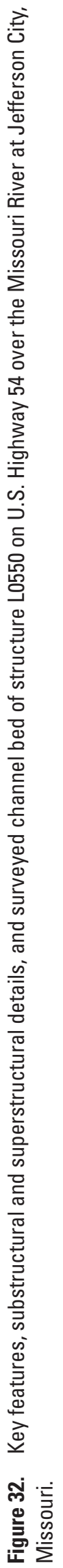




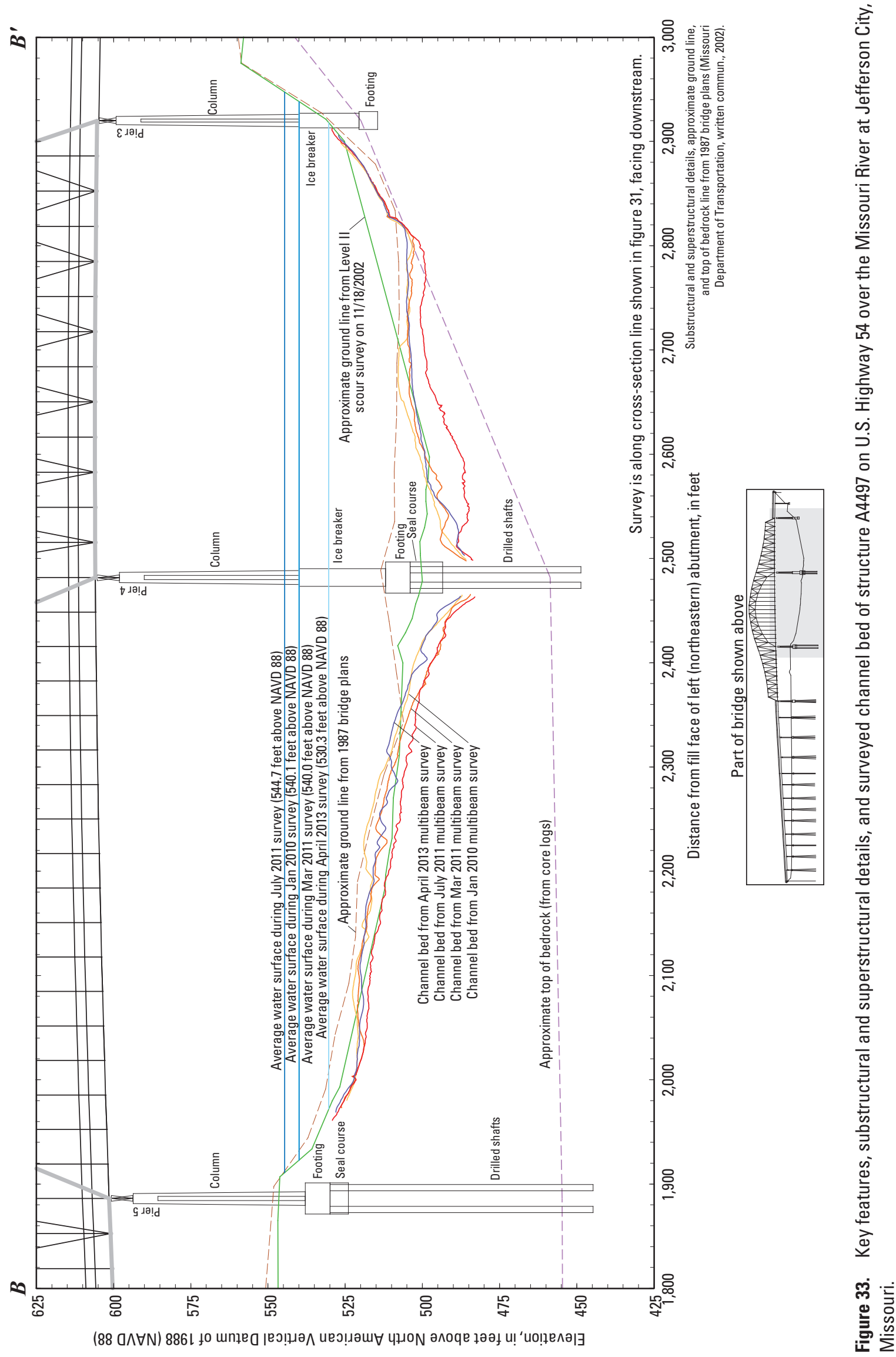




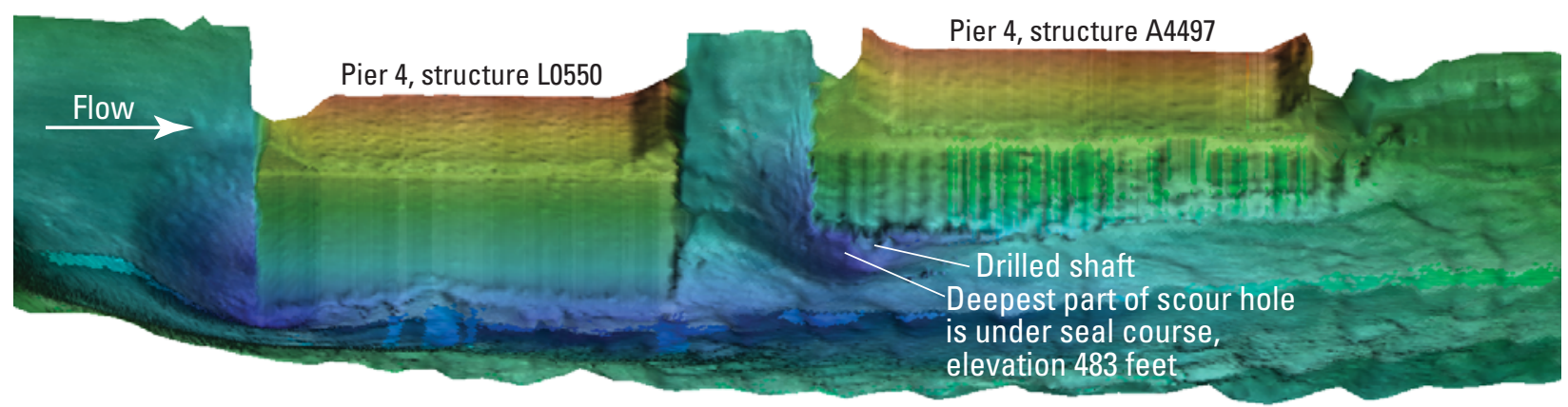

\section{EXPLANATION}

Elevation of point, in feet above the North American Vertical Datum of 1988

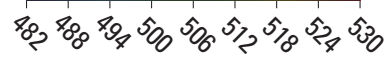

Figure 34. Shaded triangulated irregular network (TIN) visualization of the channel bed and right (southwest) side of main channel piers of structures L0550 and A4497 on U.S. Highway 54 over the Missouri River at Jefferson City, Missouri.

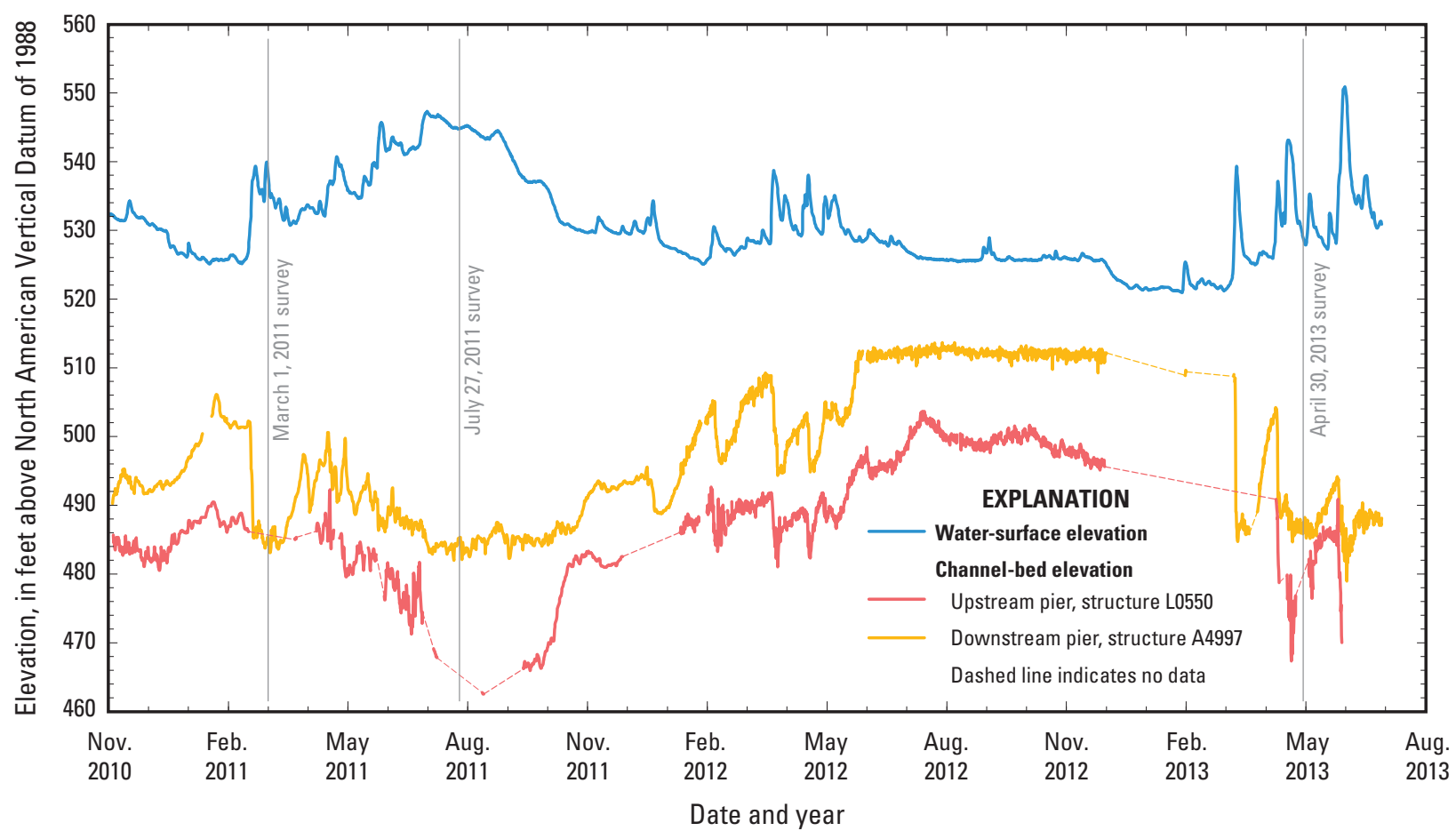

Figure 35. Water-surface and channel-bed elevations as recorded at the real-time scour monitors on the upstream nose of the upstream and downstream main channel piers of structures L0550 and A4497 on U.S. Highway 54 crossing the Missouri River at Jefferson City, Missouri, for the period November 1, 2010, to June 30, 2013. 

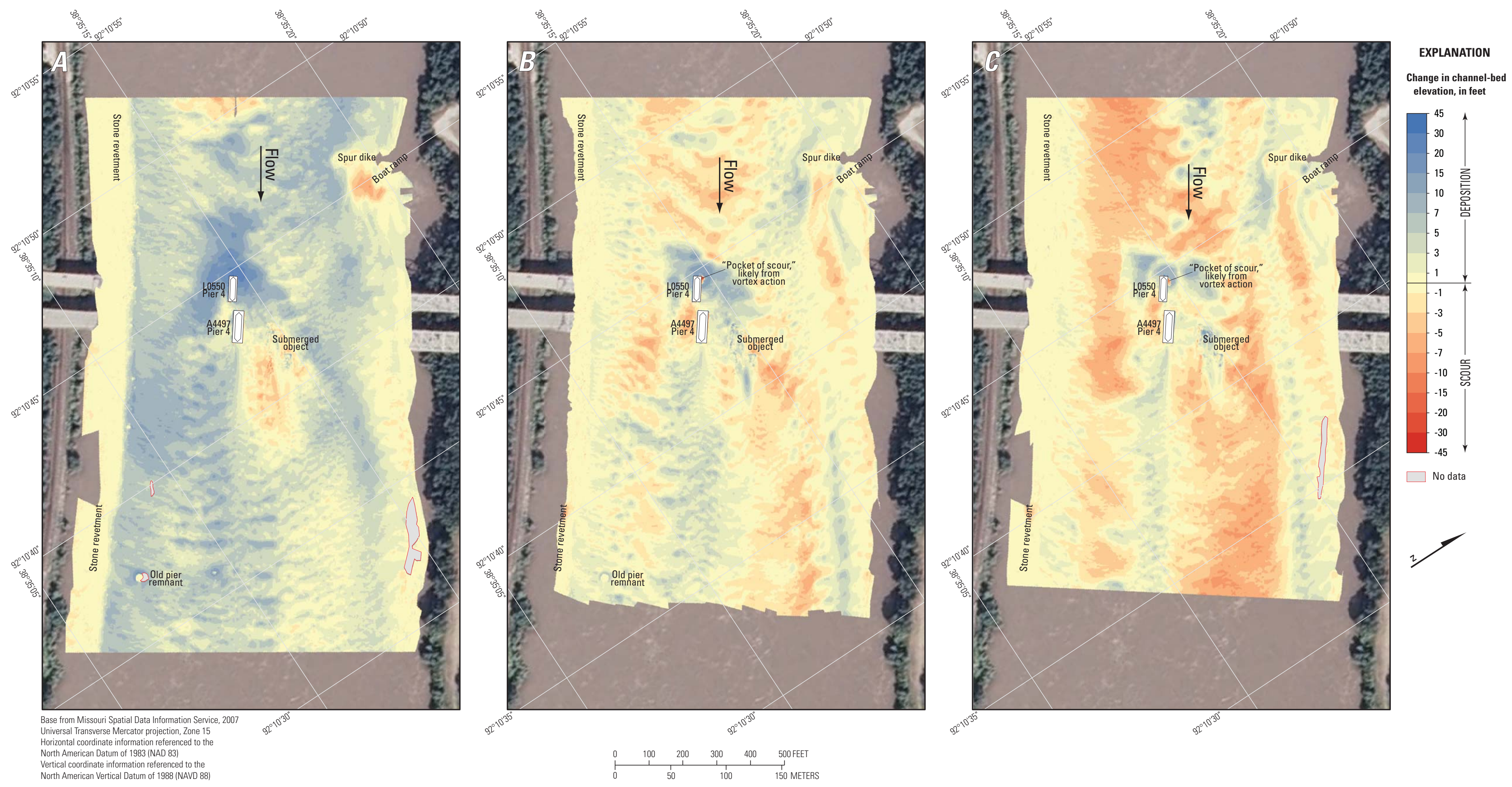

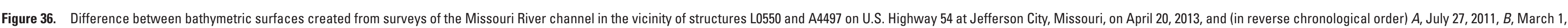
2011, and $C$, January $26,2010$. 


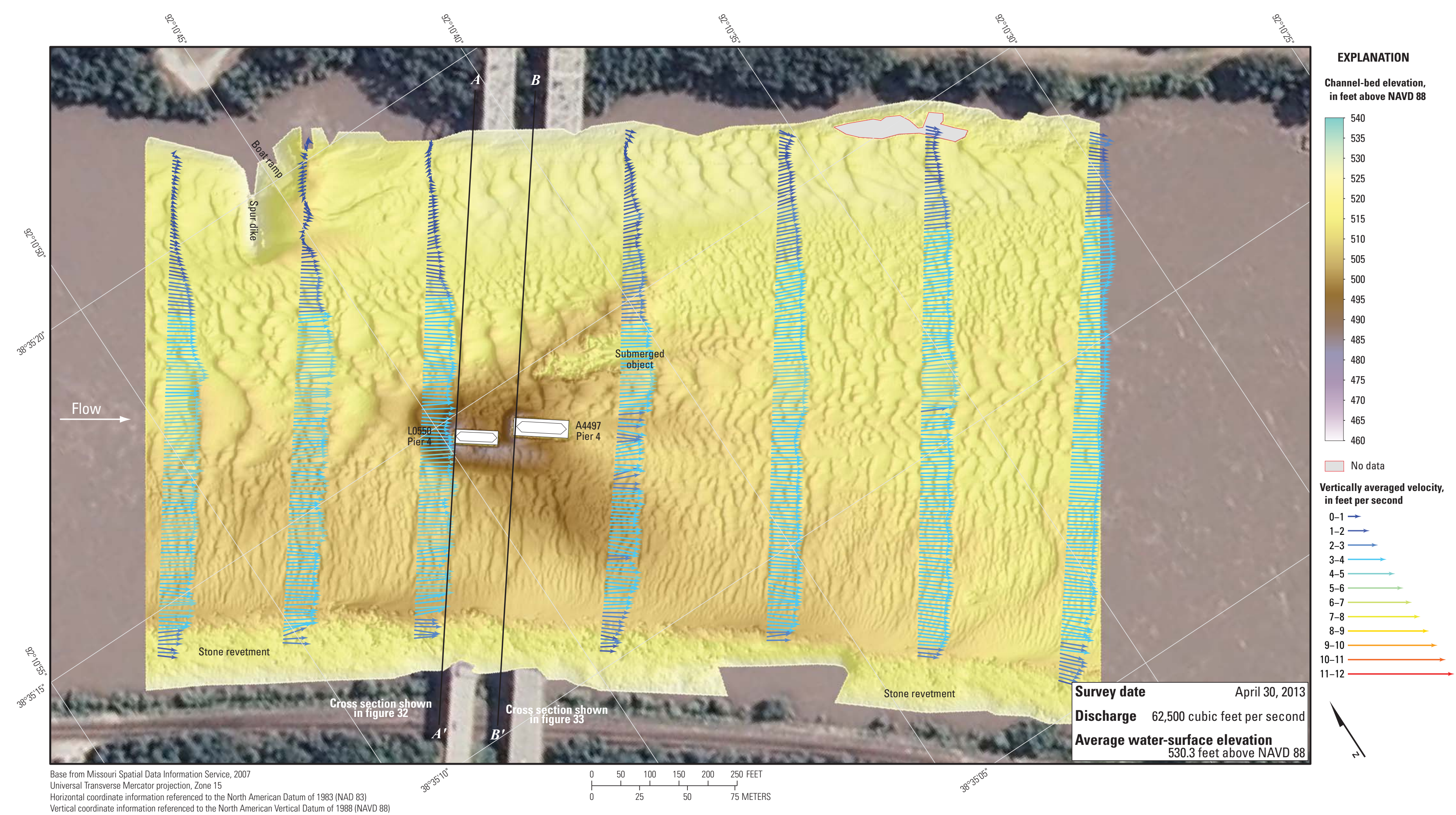

Figure 37. Bathymetry and vertically averaged velocities of the Missouri River channel in the vicinity of structures L0550 and A4497 on U.S. Highway 54 at Jefferson City, Missouri. 


\section{Structure A6288 on State Highway 19 at Hermann, Missouri}

Structure A6288 (site 21) on State Highway 19 crosses the Missouri River at RM 97.9 at Hermann, Mo., east of Jefferson City and west of St. Louis, Mo. (fig. 1; table 1). The site was surveyed on May 2, 2013, and the average water-surface elevation of the river in the survey area, determined by the RTK GNSS tide solution, was $494.6 \mathrm{ft}$ (table 2). Discharge on the Missouri River was about $108,000 \mathrm{ft}^{3} / \mathrm{s}$ during the survey (table 2).

The survey area was about $1,840 \mathrm{ft}$ long and about $1,120 \mathrm{ft}$ wide, generally extending from the longitudinal spur dikes on the left (north) bank to the right (south) bank in the main channel (fig. 38). The upstream end of the survey area was about $690 \mathrm{ft}$ upstream from the centerline of structure A6288 at pier 5 (fig. 38), and piers 4 through 6 were in the water. The channel-bed elevations ranged from about 467 to $481 \mathrm{ft}$ for most of the surveyed area ( 5 to 95 percentile range of the bathymetric data), except near the upstream toe of the downstream left longitudinal spur dike that had a local minimum channel-bed elevation of $458 \mathrm{ft}$ (fig. 38; table 2). A poorly defined thalweg was present along the left bank, and numerous small dunes and ripples were present throughout the channel (fig. 38). The part of the channel bed between the longitudinal spur dikes on the upstream left bank was surveyed using the tilted head configuration of the MBES (fig. 38); however, a shallow area behind the longitudinal spur dike prevented surveying near pier 6 (fig. 38).

Minor scour holes were observed near both of the piers in the main channel (fig. 38). The minor scour hole near pier 5 had a minimum channel-bed elevation of about $468 \mathrm{ft}$ (table 6), which is about $24 \mathrm{ft}$ above the elevation of the bottom of the pier seal course of $444.50 \mathrm{ft}$ (fig. 39; table 6). The minor scour hole near pier 4 had a minimum channel-bed elevation of about $469 \mathrm{ft}$ (table 6), which is about $18 \mathrm{ft}$ above the elevation of the bottom of the pier seal course of $451.50 \mathrm{ft}$ (fig. 39; table 6). Both scour holes were difficult to discern from nearby dunes and ripples. Information from bridge plans indicates that piers 4 and 5 are founded on shafts drilled as much as $26 \mathrm{ft}$ into bedrock, having about $54 \mathrm{ft}$ of bed material between the bottom of the scour hole and bedrock at pier 5 , and about $26 \mathrm{ft}$ of material at pier 4 (fig. 39; table 6). The surveyed bed generally was similar to the previous multibeam survey in 2011, which was similar to the original ground line in 2001 from bridge plans (fig. 39).

The difference between the surveys on May 2, 2013, and July 28, 2011 (fig. 40), indicates minor deposition throughout the channel. Moderate deposition of as much as $10 \mathrm{ft}$ has occurred throughout much of the channel, except for scour at the upstream face of the upstream left longitudinal spur dike, and the series of alternating scour and deposition patches along the middle of the channel from the series of medium and large dunes in the July 2011 survey (fig. 40). The mean difference between the July 2011 and May 2013 bathymetric surfaces (1.18 ft; table 7$)$ indicates minor to moderate deposition overall.

The vertically averaged velocity vectors indicate mostly uniform flow throughout the middle of the channel, ranging from about 4 to $6 \mathrm{ft} / \mathrm{s}$ (fig. 41). Moderate turbulence was observed along the right side of the channel and upstream from the upstream left longitudinal spur dike (fig. 41). The bridge piers were skewed to flow, but caused only minor turbulence downstream (fig. 41).

Structure A6288 on State Highway 19 at Hermann, Missouri. 


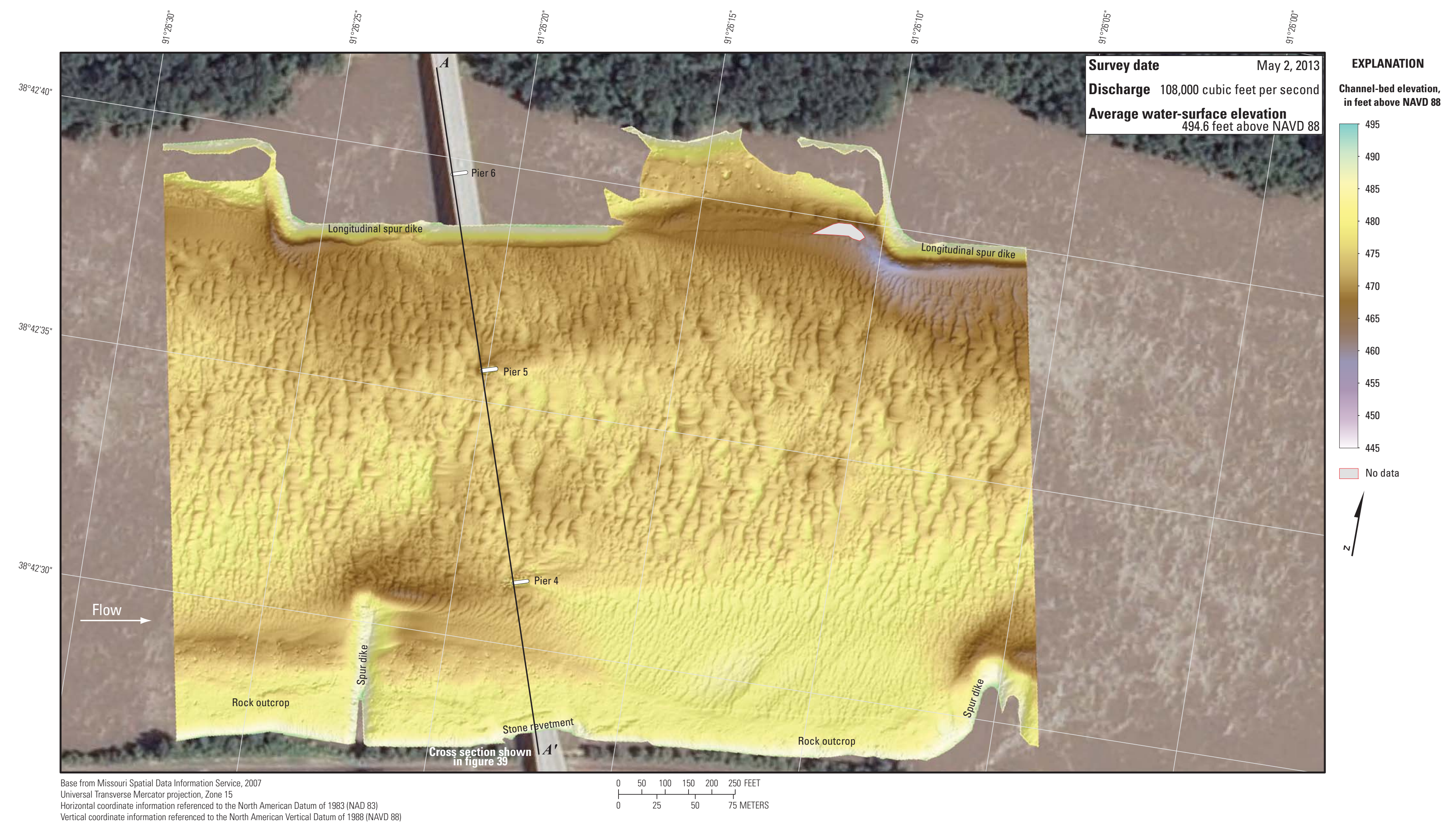

Figure 38. Bathymetric survey of the Missouri River channel in the vicinity of structure A6288 on State Highway 19 at Hermann, Missouri. 


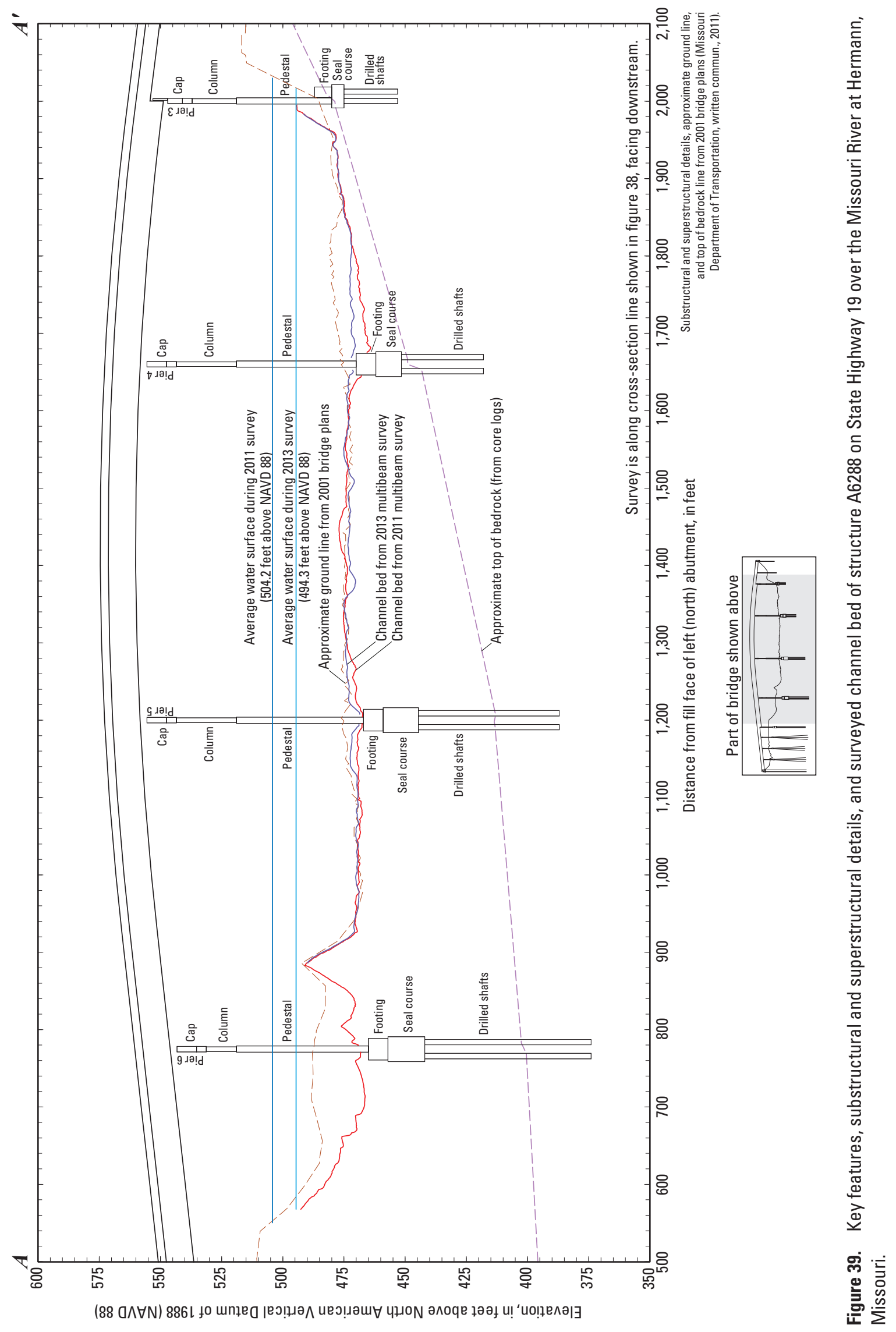




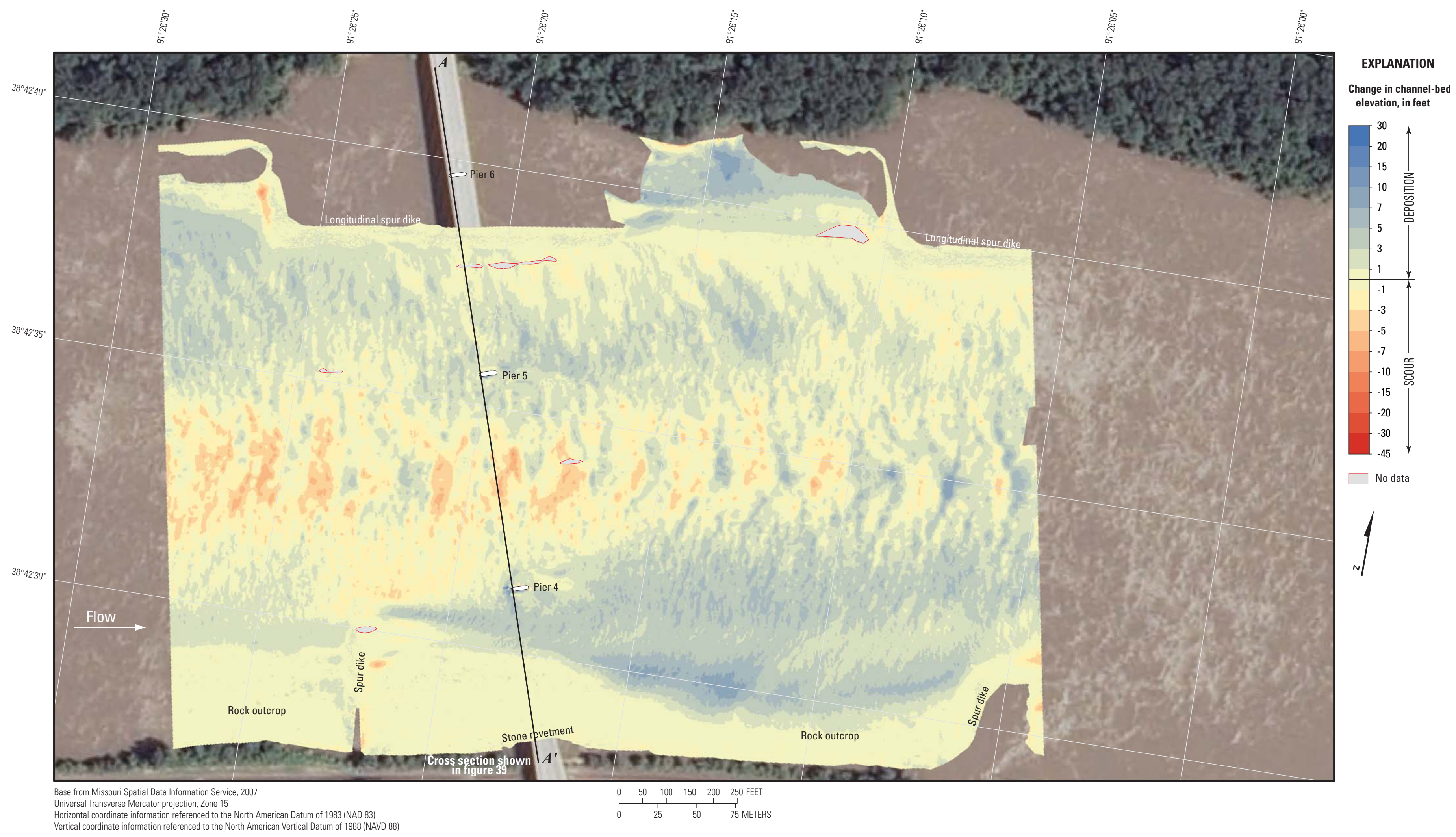

Figure 40. Difference between bathymetric surfaces created from surveys of the Missouri River channel in the vicinity of structure A6288 on State Highway 19 at Hermann, Missouri, on May 2, 2013 , and July 28, 2011. 


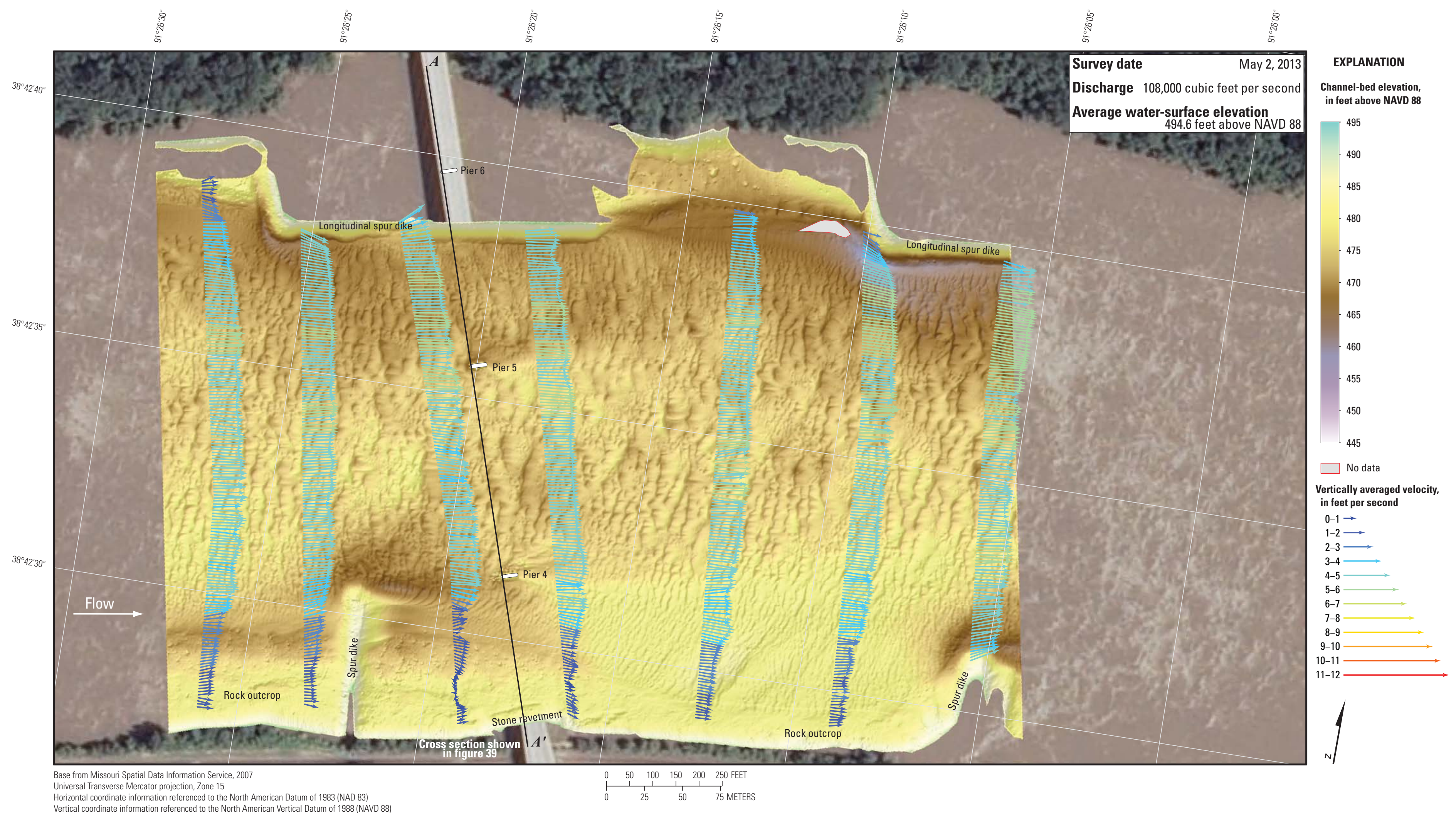

Figure 41. Bathymetry and vertically averaged velocities of the Missouri River channel in the vicinity of structure A6288 on State Highway 19 at Hermann, Missouri. 


\section{Structure K0969 on State Highway 47 at Washington, Missouri}

Structure K0969 (site 22) on State Highway 47 crosses the Missouri River at RM 67.6 at Washington, Mo., east of Hermann and west of St. Louis, Mo. (fig. 1; table 1). The site was surveyed first, on April 22, 2013, during a moderate flood event at the site (site 22, fig. 2), and the average water-surface elevation of the river in the survey area, determined by the RTK GNSS tide solution, was $477.6 \mathrm{ft}$ (table 2). Discharge on the Missouri River was about 245,000 $\mathrm{ft}^{3} / \mathrm{s}$ during the survey (table 2).

The survey area was about 1,640 ft long and about $1,250 \mathrm{ft}$ wide for most of the area, extending from about $250 \mathrm{ft}$ to the right of the left (north) bank to the right (south) bank; an attempt was made to survey along the left bank, but substantial amounts of floating debris prevented this except for the downstream one-third of the survey area (fig. 42). The upstream end of the survey area was about $570 \mathrm{ft}$ upstream from the centerline of structure K0969 (fig. 42), and piers 4 through 6 were in the water. The channel-bed elevations ranged from about 440 to $457 \mathrm{ft}$ for most of the surveyed area ( 5 to 95 percentile range of the bathymetric data), except in the scour hole at pier 5 and downstream from the downstream left (north) spur dike that had a local minimum channel-bed elevation of about $427 \mathrm{ft}$ (fig. 42). A thalweg was present along the right (south) bank and deepened in a downstream direction throughout the reach (fig. 42). A series of medium dunes were present in the middle of the channel, and numerous small dunes and ripples were present throughout the rest of the channel (fig. 42). An unusual, nearly planar area was present between piers 5 and 6 (fig. 42).

Scour holes were observed near piers 5 and 6 (fig. 42). There was a substantial scour hole in the vicinity of main channel pier 5 (fig. 42), having a minimum channel-bed elevation of about $429 \mathrm{ft}$ (table 6), which is about $15 \mathrm{ft}$ below the average channel-bed elevation upstream from the pier (fig. 43; table 6). The moderate scour hole near pier 6 (fig. 42) had a minimum channel-bed elevation of about $444 \mathrm{ft}$ (table 6), which is about $12 \mathrm{ft}$ below the average channel-bed elevation upstream from the pier (fig. 43; table 6). Information from bridge plans indicates that piers 5 and 6 are founded on caissons on bedrock, having about $54 \mathrm{ft}$ of bed material between the bottom of the scour hole and bedrock at pier 6 , and about $36 \mathrm{ft}$ of material at pier 5 (fig. 43; table 6). Pier 4 was embedded in the longitudinal spur dike, and the minimum channel elevation at the toe of the dike was about $448 \mathrm{ft}$ (figs. 42 and 43; table 6). Pier 4 is founded on a footing on bedrock, and bedrock was exposed at the toe of the spur dike (fig. 43; table 6); however, the rock of the spur dike likely will limit or prevent a local scour hole near pier 4 . The surveyed bed generally was similar to the previous multibeam survey in July 2011, except near pier 5 where there was 5 to $10 \mathrm{ft}$ of deposition (fig. 43) that caused the scour hole near that pier to be smaller and shallower in 2013 than in 2011.

The difference between the surveys on April 22, 2013, and July 27, 2011 (fig. 44), indicates a rough balance between scour and deposition throughout the channel. Moderate to substantial scour of as much as $20 \mathrm{ft}$ has occurred downstream from the spur dike on the left bank and on the left side of the channel near the upstream end of the reach, whereas moderate deposition of as much as $15 \mathrm{ft}$ has occurred in the middle of the channel and near pier 5 (fig. 44). The mean difference between the July 2011 and April 2013 bathymetric surfaces $(0.15 \mathrm{ft}$; table 7$)$ indicates essentially no net change overall, as evident in the difference map (fig. 44). The series of medium dunes evident in the July 2011 survey is indicated by a series of alternating scour and deposition patches upstream from pier 5 (fig. 44). Minor deposition was observed on the rock outcrop between the right (south) longitudinal spur dike and the right bank and downstream (fig. 44).

The vertically averaged velocity vectors indicate mostly uniform flow in the middle of the channel, with velocities ranging from about 4 to $10 \mathrm{ft} / \mathrm{s}$ (fig. 45). Local lower velocities and turbulence were observed downstream from the various spur dikes on both banks (fig. 45). The bridge piers were aligned with flow, and caused little to no evident turbulence downstream (fig. 45).

Structure K0969 on State Highway 47 at Washington, Missouri. 


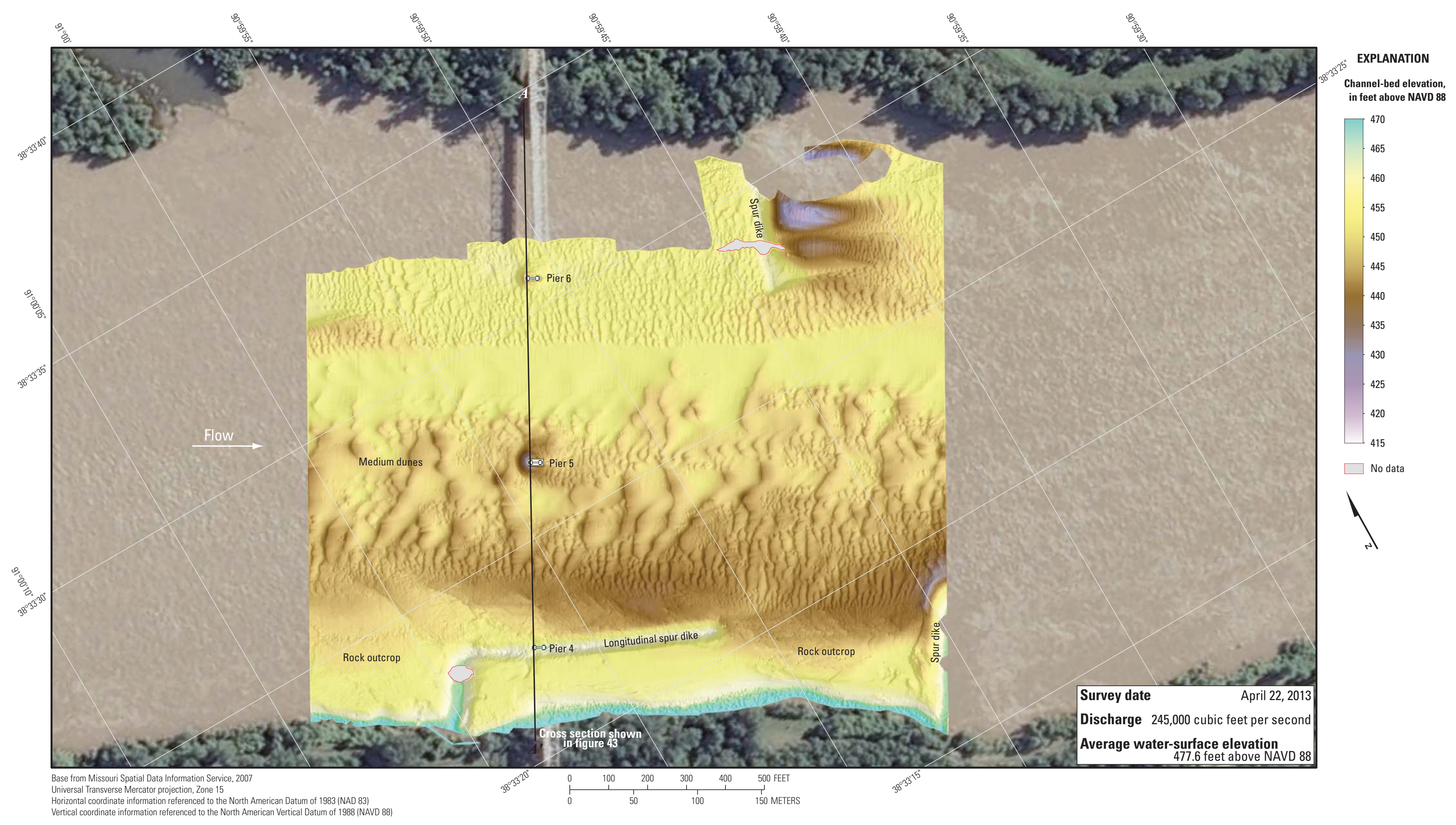

Figure 42. Bathymetric survey of the Missouri River channel in the vicinity of structure K0969 on State Highway 47 at Washington, Missouri. 


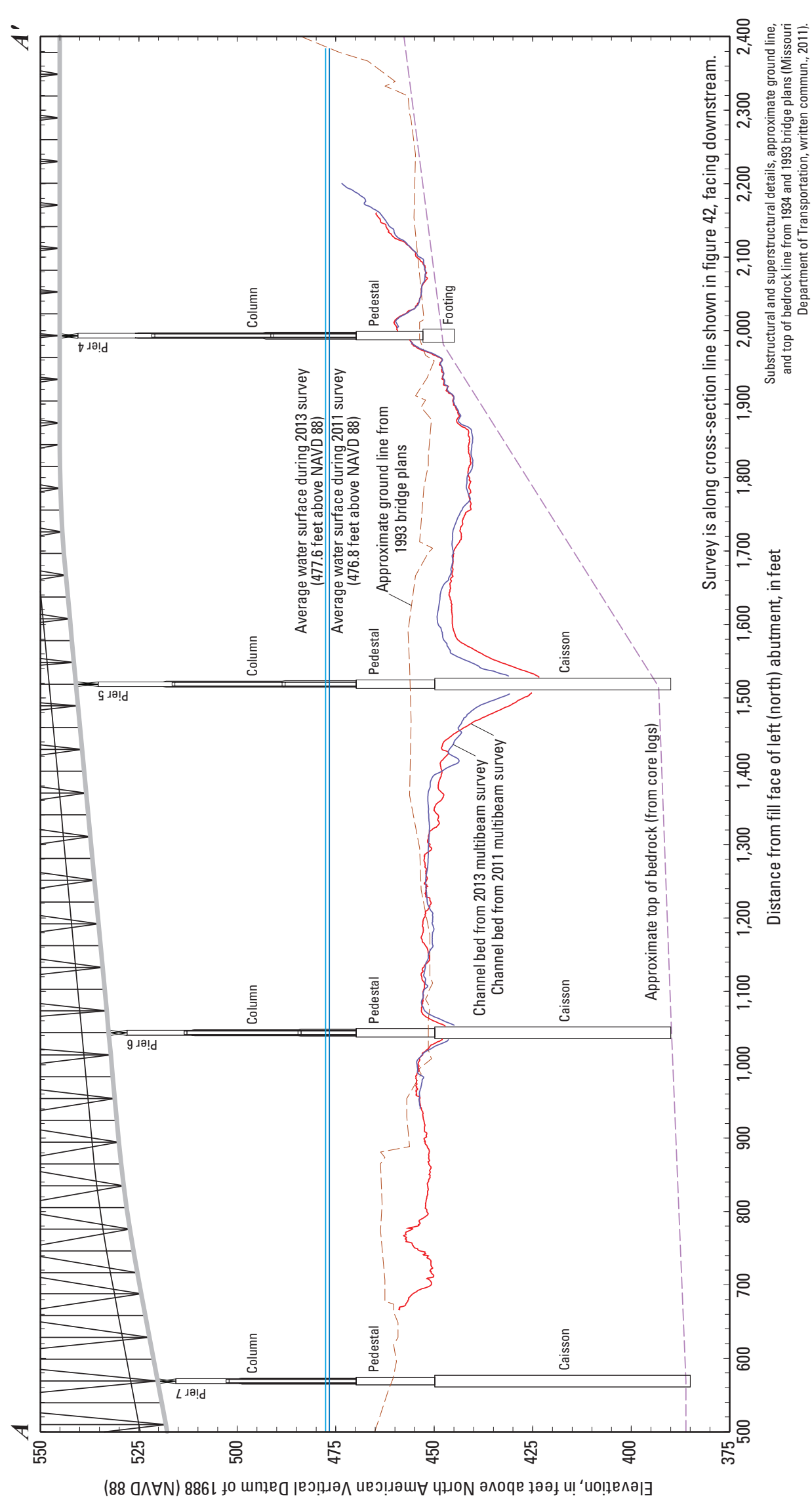

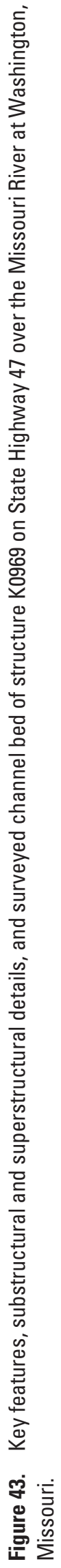




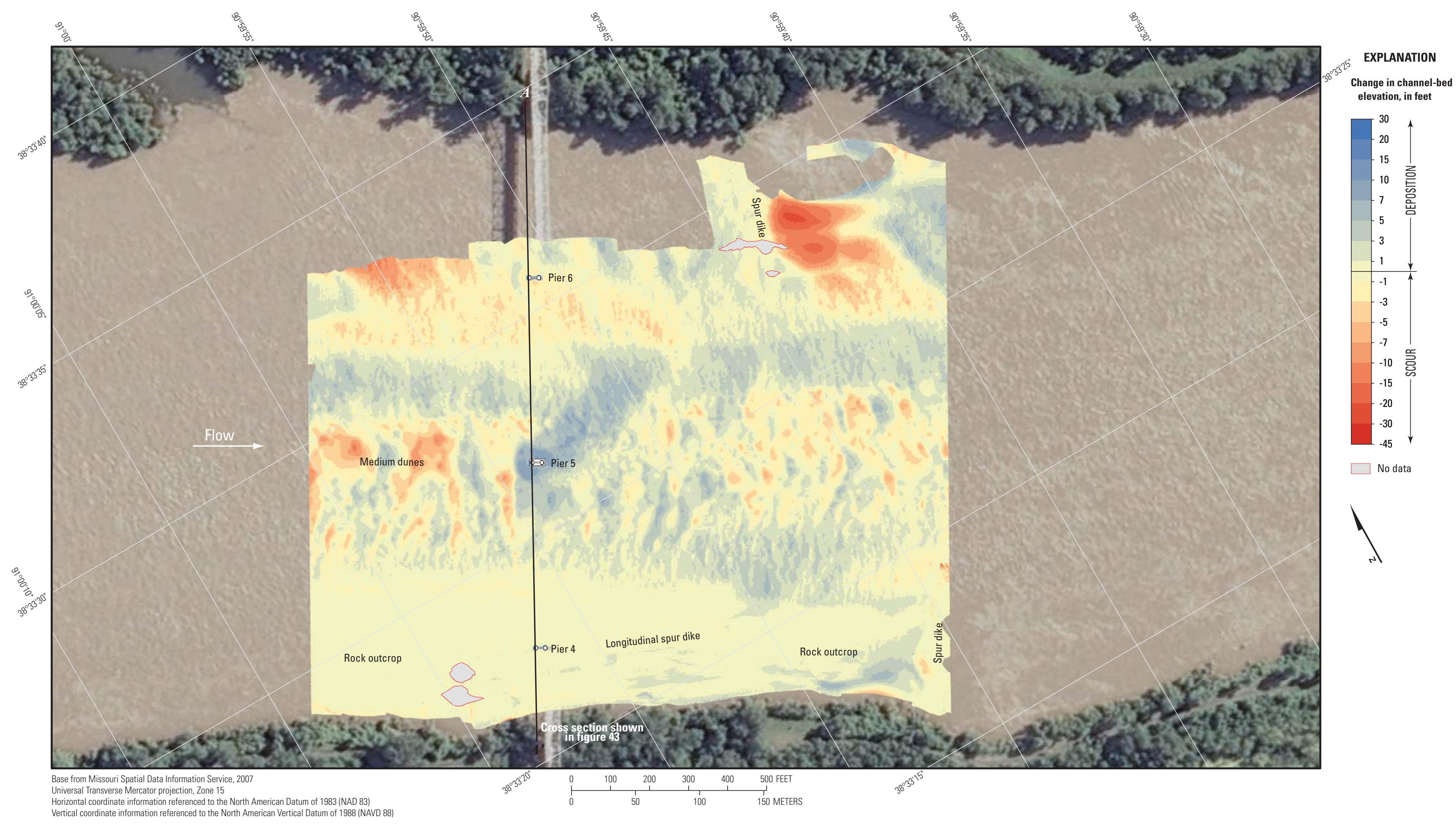

Figure 44. Difference between bathymetric surfaces created from surveys of the Missouri River channel in the vicinity of structure K0969 on State Highway 47 at Washington, Missouri, on April 22, 2013 , and July 27, 2011. 


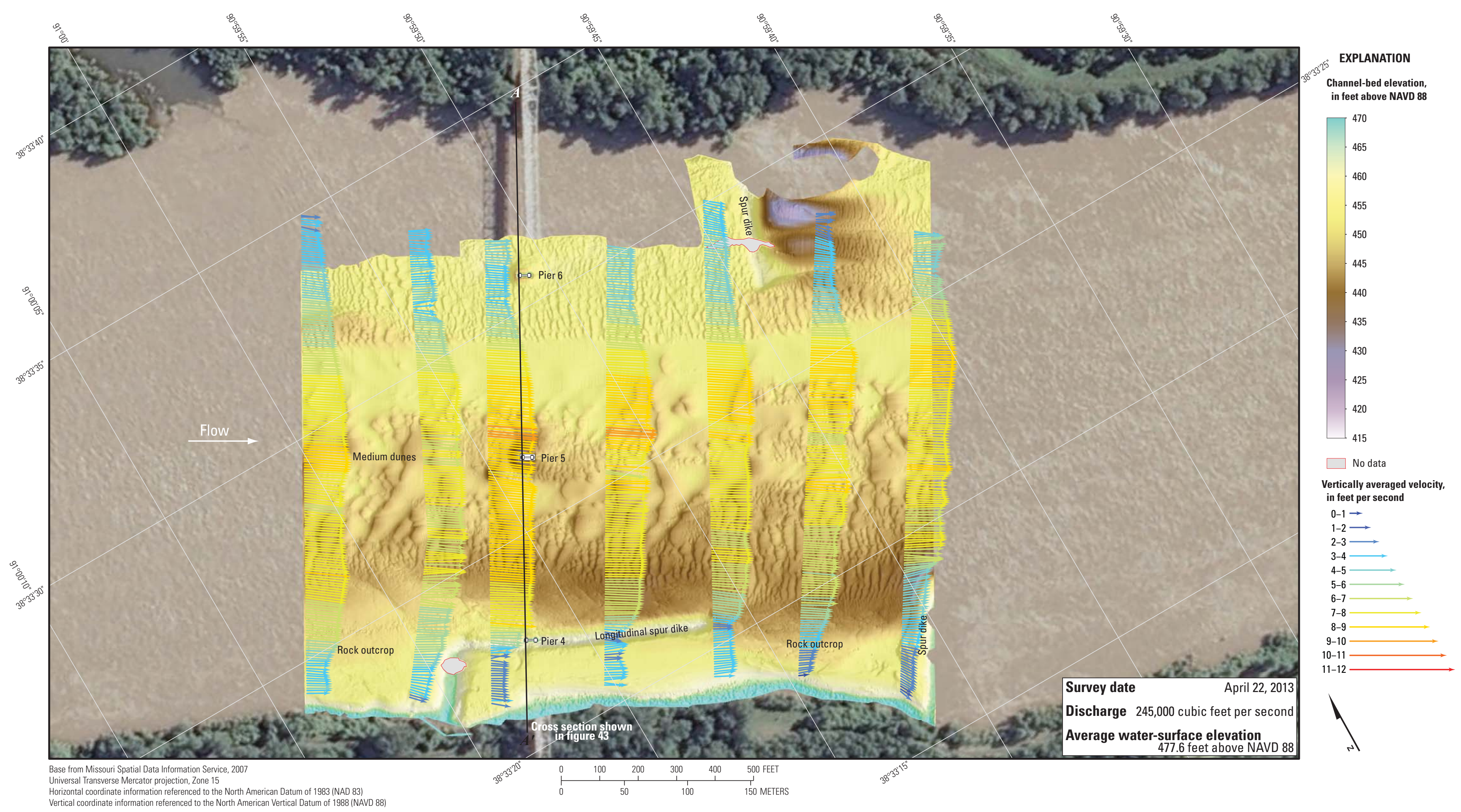

Figure 45. Bathymetry and vertically averaged velocities of the Missouri River channel in the vicinity of structure K0969 on State Highway 47 at Washington, Missouri. 


\section{General Findings and Implications}

Several of the findings at each surveyed bridge were common to all of the bridges, and some findings were evident only when the surveys were examined as a set. These general findings are of benefit in the assessment of scour at the surveyed bridges, as well as other bridges in the vicinity or in similar settings.

\section{Effects of Low to Moderate Flooding Compared to Previous Surveys}

Richardson and Davis (2001) separate long-term aggradation and degradation of a channel from the contraction and local scour that occurs at a bridge site during floods. Contraction scour is the general change in the channel-bed elevation across a bridge opening resulting from the passage of a flood through a constriction. Local scour is the localized erosion of material caused by flow vortex action that forms near bridge piers and abutments. Although all of the scour processes (longterm, contraction, and local scour) continually are at work, contraction and local scour generally are cyclic, and result in a decrease and subsequent increase of the channel-bed elevation during the passage of a flood.

Many flood durations on the Missouri can be measured in weeks and months because of the large upstream contributing drainage area; however, as described in the "Description of flow conditions" section earlier in this report, most of the surveys in this study were on the recession side of a shortduration flood pulse (fig. 2). The fixed scour monitors on structures L0550 and A4997 at Jefferson City, Mo., indicate that many of the scour holes observed at the upstream nose of the piers does not fill in rapidly after the recession of a flood (fig. 35); nevertheless, deposition does occur in the scour holes upon flood recession. Therefore, it might be reasonable to assume that the scour holes near the piers and the general scour observed under the bridge crossings might be of a lesser magnitude than that observed during a previous survey in July during the 2011 flood. Generally, this assumption proved to be true, particularly in respect to the depth of observed scour near the piers when compared to results from the 2011 flood.

Flows ranged from about 20 to 30 percent of the 2011 flow rate for the sites upstream from and including Jefferson City, Mo. (sites 14 to 20), during the 2013 surveys, and watersurface elevations were about 14 to $18 \mathrm{ft}$ lower in 2013 than in 2011 (table 7). At structure A6288 at Hermann, Mo. (site 21), the flow was 50 percent of the 2011 flow rate, and the 2013 water-surface elevation was $9.6 \mathrm{ft}$ lower than in 2011 (table 7). At structure K0969 at Washington, Mo. (site 22), the flow was 114 percent of the 2011 flow rate, and the 2013 watersurface elevation was $0.8 \mathrm{ft}$ higher than in 2011 (table 7). However, all but one (site 16) of the bathymetric surfaces from the 2013 surveys were higher than the 2011 surveys, with the mean difference between the bathymetric surfaces varying from $0.5 \mathrm{ft}$ lower to $4.4 \mathrm{ft}$ higher in 2013 than 2011 (table 7).
Structure K0999 at Miami, Mo. (site 16), was the one site with a negative mean difference between the bathymetric surfaces from 2011 to 2013, which indicates overall net scour between the compared bathymetric surfaces; however, this site had substantially less area covered in 2013 than in 2011 (nearly 40 percent less; table 7), and the area surveyed was along the bedrock thalweg and away from the observed deposition on the left bank downstream from the spur dike (fig. 16). It is likely that the area not surveyed in 2013 would have experienced deposition because it is on the inside of a bend in the river, and is implied by the deposition observed along the left edge of the 2013 survey area. The statistics of the differences between the bathymetric surfaces for that site may have been skewed by not including this area of potential deposition.

The depth of the scour holes from the upstream channel bed near the piers generally was greater in 2011 than in 2013 [table 7, compared with table 9 from Huizinga (2012)], which is consistent with the higher flow conditions. At more than one-half of the sites, the scour holes were less than $5 \mathrm{ft}$ deeper in 2011 than in 2013; however, at pier 5 of structure K0999 on State Highway 41, the scour hole was almost $8 \mathrm{ft}$ deeper in 2011 than in 2013 (fig. 16), and at pier 4 of upstream structure L0550 on U.S. Highway 54, the scour hole was more than $20 \mathrm{ft}$ deeper in 2011 than in 2013 (fig. 36). The slight difference in pier scour depth at most of the piers implies that they are well-aligned with flow and narrow in aspect, with efficient nose shapes and substructural elements that are below the average channel bed during flood conditions. The moderate- to high-flow conditions during the summer 2011 flood did result in greater scour hole depths, but the effects of the higher flow conditions appeared to be mitigated by the shape and alignment of the piers at these sites.

The multiple surveys at structures L0550 and A4497 at Jefferson City, Mo. (site 20), indicate that the flow condition is not the sole variable in the determination of the size of scour holes at sites with a dual bridge configuration. The channel cross sections from the multiple surveys near the pier of upstream structure L0550 (fig. 32) show that the scour holes differed in depth by $5 \mathrm{ft}$ or more in all of the four surveys, even though the January 2010 and March 2011 flow conditions were similar (water-surface elevation difference of $0.1 \mathrm{ft}$ and flow difference of $10,000 \mathrm{ft}^{3} / \mathrm{s}$; table 7). Nevertheless, the scour hole is the smallest and shallowest in the April 2013 survey, which is consistent with the pier scour predictive equations in Richardson and Davis (2001). Conversely, the channel cross sections near the pier of downstream structure A4497 (fig. 33) show that the scour holes did not differ in depth by more than $5 \mathrm{ft}$ in all of the four surveys, despite the similar flow conditions of the January 2010 and March 2011 flows, and their difference from the July 2011 and April 2013 flows. Perhaps the turbulence from the upstream pier creates a particular scour scenario at the downstream pier that does not substantially change despite the flow conditions; however, the fixed single-beam monitors on the piers at this site capture the dynamic nature of the channel bed and document the formation of scour holes driven by moderate- to high-flow events 
that are generally followed by aggradation of the channel bed during the time between high-flow events (fig. 35). The downstream monitor indicates that the depth of scour ultimately observed is not purely a function of the observed discharge, and yet also is not a constant value in all flow conditionsalthough it appears that a relatively constant value often is reached in a series of events that are closely spaced temporally (fig. 35).

A comparison of the dune sizes at the various sites also is indicative of the different flow regimes between 2011 and 2013. At most of the sites, the dunes were smaller in magnitude, sometimes substantially, in 2013 than in 2011 (structure L0962 at Rocheport, Mo., figs. 27 and 29). Only structure A5664 at Lexington, Mo., and structure K0969 at Washington, Mo., had similar dune sizes in the 2011 and 2013 surveys. At structure K0969, the similarity likely is the result of the similar discharge values in the two surveys even though the dunes appear out of phase in the difference map (fig. 44). At structure A5664, although the size classification established by Huizinga (2012) and used in this study was the same ("medium"), the physical size was not; in 2011 the dunes typically were 7 to $9 \mathrm{ft}$ tall, which is on the large side of the "medium" classification, whereas in 2013 the dunes typically were 5 to $6 \mathrm{ft}$ tall, which is on the small side of the "medium" classification. Furthermore, the dunes were more irregular in form and placement in 2013 compared to 2011.

\section{Size and Shape of Scour Holes}

Generally, every pier in the main channel area for which bathymetry could be obtained had some sort of scour hole, except those on banks or embedded in spur dikes. However, the size and shape of these holes was different from one bridge to the next and occasionally even at the same bridge site. As discussed in Huizinga (2012), the local pier scour equation in Richardson and Davis (2001) indicates pier scour is a function of several factors, including the depth and velocity of approach flow, the width and nose shape of the pier, the angle of approach flow, and the condition and armoring of the channel bed. Several of these factors are discussed below.

For the various bridges in this study, flow velocities generally were greater in the deeper parts of the channel (the thalweg), and lower in the shallow parts of the channel. Of course, there were local exceptions, such as downstream from a spur dike where a local deep area may have had a low velocity (for example, figs. 17, 26, 30, and 45). Exceptions notwithstanding, the size of the scour holes at sites having more than one pier in the water was related to the depth and velocity of flow upstream from the pier in question, and consistent with the local pier scour equation in Richardson and Davis (2001); deeper flow or higher velocity generally resulted in larger, deeper scour holes than shallow flow or lower velocities (figs. 22, 26, 41, and 45) in the absence of a spur dike or rock outcrop that might limit local scour (pier 4 in fig. 45). Similar findings have been observed during the various studies using the MBMS in Missouri (Huizinga, 2010, 2011, 2012).
Also consistent with the local pier scour equation in Richardson and Davis (2001), piers having wide or blunt noses resulted in larger, deeper scour holes than those having narrow, round, or sharp noses. In fact, narrow piers having round or sharp noses that were aligned with flow often had scour holes that were difficult to discern from nearby small dunes and ripples (figs. 6, 10, 23, and 38), whereas the scour hole generally was substantial near piers having blunt noses (figs. 14, 18, 31, and 42) and those that were rounded but wide relative to their length (fig. 27). When the channel bed immediately upstream from a pier was above the top of a footing, the scour holes near that pier occasionally did not penetrate below the top of the footing (pier 21, fig. 7; pier 7, fig. 24; and pier 5, fig. 39); the footing effectively was a scour limiter at these piers. Similar findings have been observed during the various studies using the MBMS in Missouri (Huizinga, 2010, 2011), particularly during the 2011 flood (Huizinga, 2012).

Several of the surveyed bridges had piers that were skewed to approach flow, resulting in asymmetric scour holes at those bridges: pier 3 of structure G0069 on State Highway 240 at Glasgow, Mo. (fig. 18), structure L0962 on Interstate 70 near Rocheport, Mo. (fig. 27), and structures L0550 and A4497 on U.S. Highway 54 at Jefferson City, Mo. (fig. 31). The scour hole typically was deeper and longer on the side of the pier with impinging flow, with some amount of deposition on the leeward side. At structure L0962, the skew to approach flow is apparent in the velocity vectors (fig. 30), but it is interesting to note that the skew to approach flow is not readily apparent at structures G0069 (fig. 22) or L0550 and A4497 (fig. 37).

In the previous studies in the Kansas City, Mo., and St. Louis, Mo., areas (Huizinga, 2010, 2011), the movement of bed material affected the bathymetric data and the shape of the scour holes at several of the bridges, such that several of the scour holes displayed subtle "steps" and waves in the front of or along the sides of the holes. These "steps" were more pronounced in the Kansas City, Mo., area bridges than in the area bridges in the previous studies, presumably because the nonflood flow conditions during the St. Louis, Mo., area surveys would result in less dynamic movement of bed material than the moderate flood conditions during the Kansas City, Mo., area surveys; subsequently, the scour holes were presumed to be less likely to have lateral or longitudinal sand input in the St. Louis, Mo., surveys. However, during the 2011 flood study (Huizinga, 2012), the Missouri River was in moderate- to high-flow conditions at all of the bridges that resulted in substantial and dynamic movement of bed material, yet "steps" and waves were observed at only a few bridges. No such "steps" or waves were observed in the current study, which was in low to moderate flow conditions. In the earliest previous survey at structures L0550 and A4497 at Jefferson City, Mo., on January 26, 2010, the "steps" and waves caused the scour hole to be nearly rectangular (apparent in the difference map; fig. 36C), whereas there were no such features apparent in the most-recent survey on April 30, 2013 (fig. 31). 


\section{Summary and Conclusions}

Bathymetric and velocimetric data were collected on the Missouri River in the vicinity of 10 highway bridges at 9 crossings between Kansas City and St. Louis, Missouri, by the U.S. Geological Survey in cooperation with the Missouri Department of Transportation. A multibeam echosounder mapping system was used to obtain channel-bed elevations for areas ranging from 1,640 to 1,840 feet long, and extending across the active channel between banks and spur dikes in the Missouri River during low- to moderate-flow conditions. These bathymetric surveys provide a "snapshot" of the channel conditions at the time of the surveys (April 22-May 2, 2013) and provide characteristics of scour holes that may be useful in the development of predictive guidelines or equations for scour holes. These data also may be used by the Missouri Department of Transportation to assess the bridges for stability and integrity issues with respect to bridge scour during floods.

The estimated total propagated uncertainty for the bathymetric surface of each survey area was computed as an estimate of the accuracy to be expected for each point with all relevant error sources taken into account. An analysis of the surveys indicated that nearly 90 percent of the bathymetric data at all the sites have a total propagated uncertainty of less than 1.00 feet, and more than one-half of the data at the five upstream-most sites have a total propagated uncertainty of 0.50 feet or less.

At all of the surveyed bridges, a variety of features were detected in the channel ranging from small ripples to medium dune features that indicate moderate transport of sediment. Rock outcrops also were detected at several sites where the alluvial material of the channel bed had been washed away, usually on one side of the channel.

Bathymetric data were collected around every pier that was in water, except those at the edge of water or in very shallow water (less than 6 feet of depth). Scour holes were present at most piers for which bathymetry could be obtained, except at piers on channel banks, those near or embedded in lateral or longitudinal spur dikes, and those on exposed bedrock outcrops. Occasionally, the scour hole near a pier was difficult to discern from nearby bed features. The observed scour holes at the surveyed bridges were examined with respect to shape and depth.
Although exposure of parts of substructural support elements was observed at several piers, at most sites the exposure likely can be considered minimal compared to the overall substructure that remains buried in bed material at these piers. The notable exceptions are pier 4 at structure K0999 on State Highway 41 at Miami, Mo., piers 2 and 3 at structure G0069 on State Highway 240 at Glasgow, Mo., and pier 5 at structure A4574 on State Highway 5 at Boonville, Mo.; at these structures, the bed material thickness between the bottom of the scour hole and bedrock was less than 6 feet. In modern construction, bridge substructural elements usually are pinned or socketed to bedrock, but full exposure of usually buried substructural elements warrants special consideration and observation. The drilled shafts under the seal course also were apparent in the survey of structure A4497 on U.S. Highway 54 at Jefferson City, Mo., but there was about 24 feet of bed material between the bottom of the surveyed scour hole and bedrock at this pier.

Previous bathymetric surveys had been done at all of the sites in this study. Comparisons between bathymetric surfaces from the previous surveys and those of this study generally indicate that there was a consistent increase in the elevation of the channel bed and decrease in the size of scour holes at these sites that was likely caused by a substantial decrease in discharge and water-surface elevation compared to the 2011 surveys at most sites. However, multiple surveys at structures L0550 and A4497 on U.S. Highway 54 at Jefferson City, Mo., indicate that the flow condition is not the sole variable in the determination of the size of scour holes at sites having a dual bridge configuration. Furthermore, the discharge at structure K0969 on State Highway 47 at Washington, Mo., was slightly greater in 2013 than in 2011, yet the scour hole near pier 5 was smaller and shallower in 2013 compared to 2011.

Pier size, nose shape, and alignment to flow had a profound effect on the size of the scour hole observed for a given pier. Narrow piers having round or sharp noses that were aligned with flow often had scour holes that were difficult to discern from nearby bed features, whereas piers having wide or blunt noses resulted in larger, deeper scour holes. Several of the structures had piers that were skewed to primary approach flow, and scour holes near these piers generally displayed deposition on the leeward side of the pier and greater depth on the side of the pier with impinging flow. 


\section{References Cited}

American Association of State Highway Transportation Officials, 2012, AASHTO LRFD bridge design specifications, Section 10, (Customary U.S. Units, 6th ed.): Washington, D.C., 167 p.

Applanix Corporation, 2009, POS-Pac ${ }^{\mathrm{TM}}$ MMS ${ }^{\mathrm{TM}}$ GNSSinertial tools user guide, rev. 4: Richmond Hill, Ontario, Canada, PUBS-MAN-001768, 523 p.

Brown, D.A., Turner, J.P., and Castelli, R.J., 2010, Drilled shafts - Construction procedures and LRFD Design Methods: U.S. Federal Highway Administration Publication FHWA-NHI-10-016 Geotechnical Engineering Circular no. $10,970 \mathrm{p}$.

Calder, B.R., and Mayer, L.A., 2003, Automatic processing of high-rate, high-density multi-beam echosounder data: Geochemistry, Geophysics, Geosystems, v. 4, no. 6, p. 1048.

Czuba, J.A., Best, J.L, Oberg, K.A., Parsons, D.R., Jackson, P.R., Garcia, M.H., and Ashmore, P., 2011, Bed morphology, flow structure, and sediment transport at the outlet of Lake Huron and in the Upper Saint Clair River: Journal of Great Lakes Research, v. 37, no. 3, p. 480-493.

Dietsch, B.J., Densmore, B.K., and Strauch, K.R., 2014, Hydrographic surveys at selected highway bridges crossing the Missouri River using a multibeam echosounder, 2011: U.S. Geological Survey Scientific Investigations Report 2014-5062, $53 \mathrm{p}$.

Densmore, B.K., Strauch, K.R., and Dietsch, B.J., 2013, Hydrographic surveys of the Missouri and Yellowstone Rivers at selected bridges and through Bismarck, North Dakota, during the 2011 flood: U.S. Geological Survey Scientific Investigations Report 2013-5087, 59 p. [Also available at http://pubs.usgs.gov/sir/2013/5087/.]

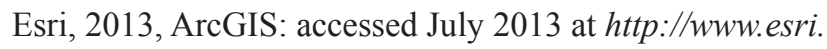
com/software/arcgis/.

Huizinga, R.J., 2010, Bathymetric surveys at highway bridges crossing the Missouri River in Kansas City, Missouri, using a multibeam echo sounder, 2010: U.S. Geological Survey Scientific Investigations Report 2010-5207, 61 p. [Also available at $h t t p: / / p u b s . u s g s . g o v /$ sir/2010/5207/.]

Huizinga, R.J., 2011, Bathymetric surveys at highway bridges crossing the Missouri and Mississippi Rivers near St. Louis, Missouri, 2010: U.S. Geological Survey Scientific Investigations Report 2011-5170, 75 p. [Also available at $h t t p: / /$ pubs.usgs.gov/sir/2011/5170/.]
Huizinga, R.J., 2012, Bathymetric and velocimetric surveys at highway bridges crossing the Missouri River in and into Missouri during summer flooding, July-August 2011: U.S. Geological Survey Scientific Investigations Report 2012-5204, 166 p. [Also available at http://pubs.usgs.gov/ sir/2012/5204/.]

Huizinga, R.J., 2013, Results of repeat bathymetric and velocimetric surveys at the Amelia Earhart Bridge on U.S. Highway 59 over the Missouri River at Atchison, Kansas, 2009-2013: U.S. Geological Survey Scientific Investigations Report 2013-5177, 50 p. [Also available at http:// pubs.usgs.gov/sir/2013/5177.]

Huizinga, R.J., 2014, Bathymetric surveys and area/capacity tables of water-supply reservoirs for the city of Cameron, Missouri, July 2013: U.S. Geological Survey Open-File Report 2014-1005, 15 p. [Also available at $h t t p: / / d x . d o i$. org/10.3133/ofr20141005.]

Huizinga, R.J., Elliott, C.M., and Jacobson, R.B., 2010, Bathymetric and velocimetric survey and assessment of habitat for pallid sturgeon on the Mississippi River in the vicinity of the proposed Interstate 70 Bridge at St. Louis, Missouri: U.S. Geological Survey Scientific Investigations Report 2010-5017, 28 p. [Also available at http://pubs.usgs.gov/ sir/2010/5017/.]

Huizinga, R.J., and Rydlund, P.H., Jr., 2004, Potential-scour assessments and estimates of scour depth using different techniques at selected bridge sites in Missouri: U.S. Geological Survey Scientific Investigations Report 2004-5213, $42 \mathrm{p}$.

HYPACK, Inc., 2011, HYPACK ${ }^{\circledR}$ Hydrographic survey software user's manual 02/11: Middletown, Conn., 1,582 p.

Lagasse, P.F., Shall, J.D., Johnson, F., Richardson, E.V., Richardson, J.R., and Chang, F., 1991, Stream stability at highway structures: U.S. Federal Highway Administration Publication FHWA-IP-90-014 Hydraulic Engineering Circular no. 20, 195 p.

Mueller, D.S., and Wagner, C.R., 2009, Measuring discharge with acoustic Doppler current profilers from a moving boat: U.S. Geological Survey Techniques and Methods, book 3, chap. A22, 72 p.

Oberg, K.A., Morlock, S.E., and Caldwell, W.S., 2005, Quality-assurance plan for discharge measurements using acoustic Doppler current profilers: U.S. Geological Survey Scientific Investigations Report 2005-5183, 35 p.

Richardson, E.V., and Davis, S.R., 2001, Evaluating scour at bridges (4th ed.): U.S. Federal Highway Administration Publication FHWA-NHI-01-001 Hydraulic Engineering Circular no. $18,378 \mathrm{p}$. 
Rydlund, P.H., Jr., 2009, Real-time river channel-bed monitoring at the Chariton and Mississippi Rivers in Missouri, 2007-09: U.S. Geological Survey Scientific Investigations Report 2009-5254, 27 p.

U.S. Army Corps of Engineers, 2004a, Upper Mississippi River System flow frequency study, appendix E: Rock Island, Ill., U.S. Army Corps of Engineers, accessed March 2014 at http://www.mvr.usace.army.mil/Portals/48/docs/ FRM/UpperMissFlowFreq/App.\%20E\%20Kansas\%20 City\%20Dist.\%20Hydrology_Hydraulics.pdf.

U.S. Army Corps of Engineers, 2004b, Engineering and design-Hydrographic surveying: Washington D.C., U.S. Army Corps of Engineers, manual no. EM 1110-2-1003, $560 \mathrm{p}$.

U.S. Geological Survey, 2003, User's manual for the National Water Information System of the U.S. Geological Survey—Automated Data Processing System (ADAPS): U.S. Geological Survey Open-File Report 2003-123, 413 p., accessed September 2010 at http://pubs.usgs.gov/of/2003/ ofr03123/.

U.S. Geological Survey, 2014, National Water Information System: U.S. Geological Survey database, accessed March 2014 at http://waterdata.usgs.gov/nwis/. 



\section{Appendix 1. Shaded Triangulated Irregular Network (TIN) Images of Channel and Side of Pier for Each Surveyed Pier}

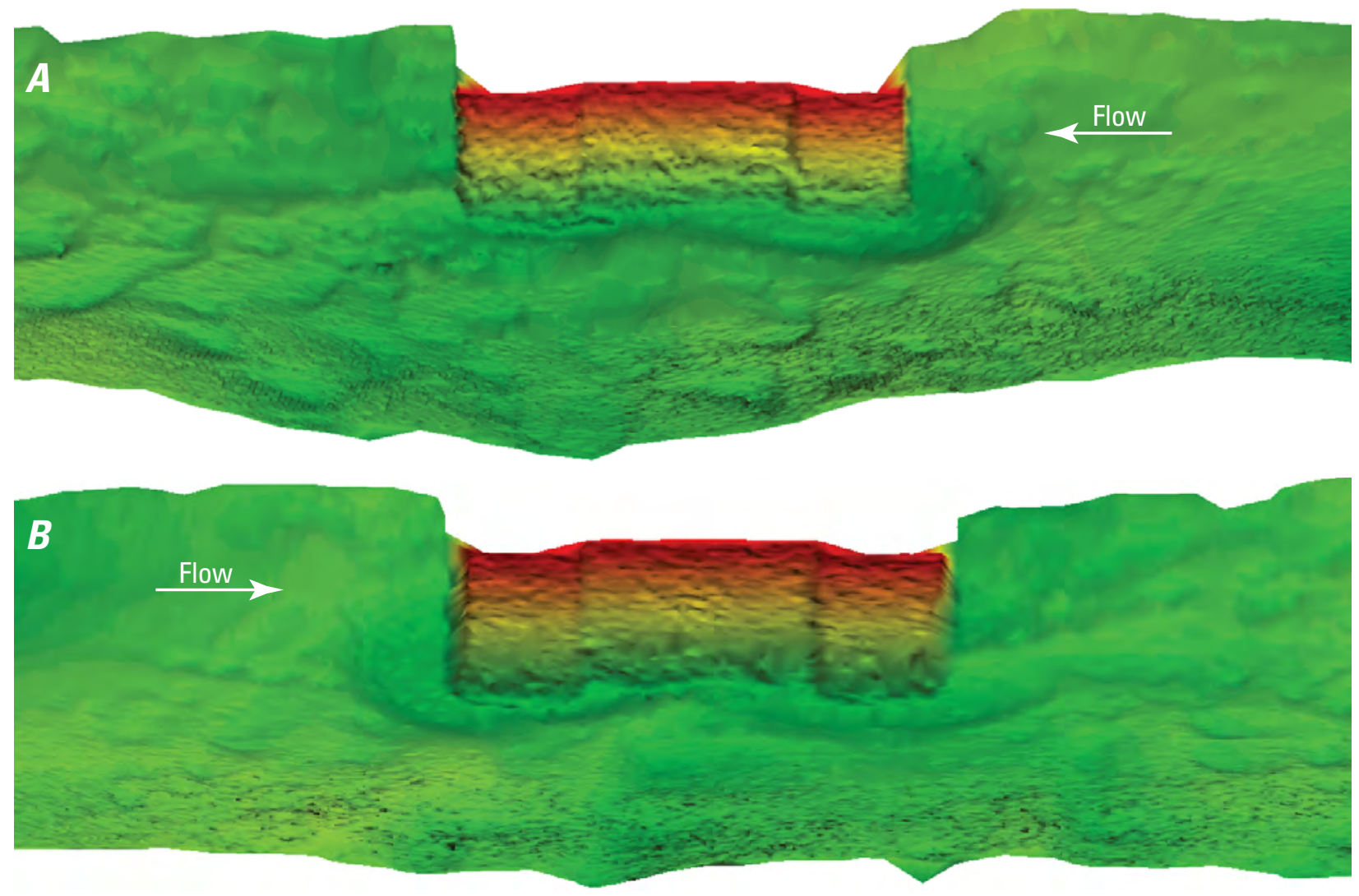

EXPLANATION

Elevation of point, in feet

above the North American

Vertical Datum of 1988

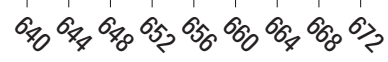

Figure 1-1. Shaded triangulated irregular network (TIN) visualization of the channel bed and $A$, left (northwest) side, and $B$, right (southeast) side of main channel pier 21 of structure A5664 on State Highway 13 over the Missouri River at Lexington, Missouri. 

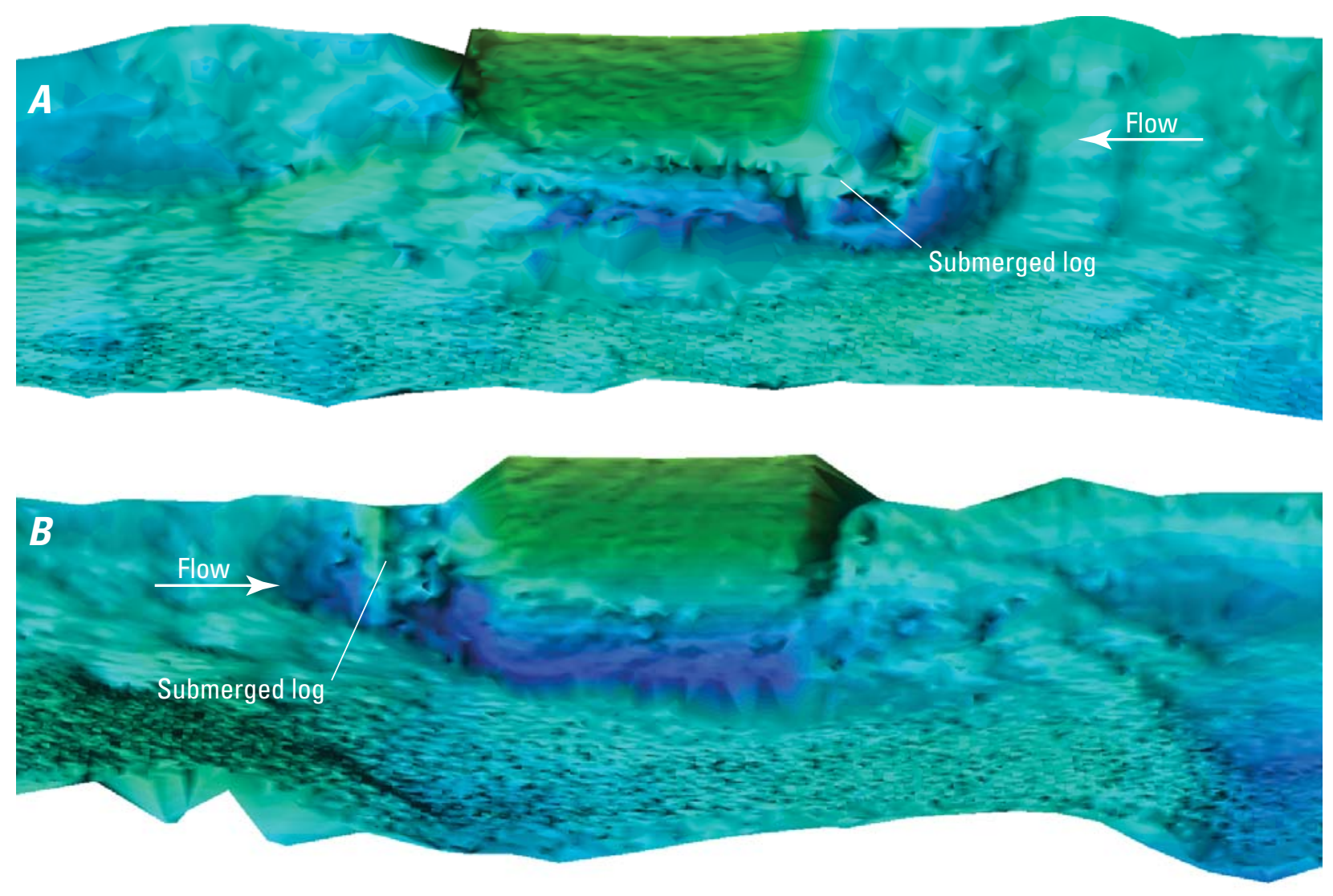

EXPLANATION

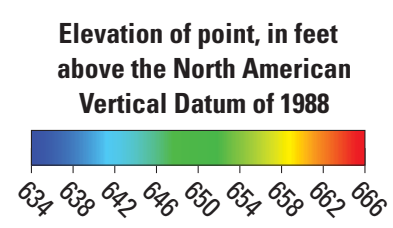

Figure 1-2. Shaded triangulated irregular network (TIN) visualization of the channel bed and $A$, left (north) side, and $B$, right (south) side of main channel pier 11 of structure A5910 on U.S. Highway 24 over the Missouri River at Waverly, Missouri. 

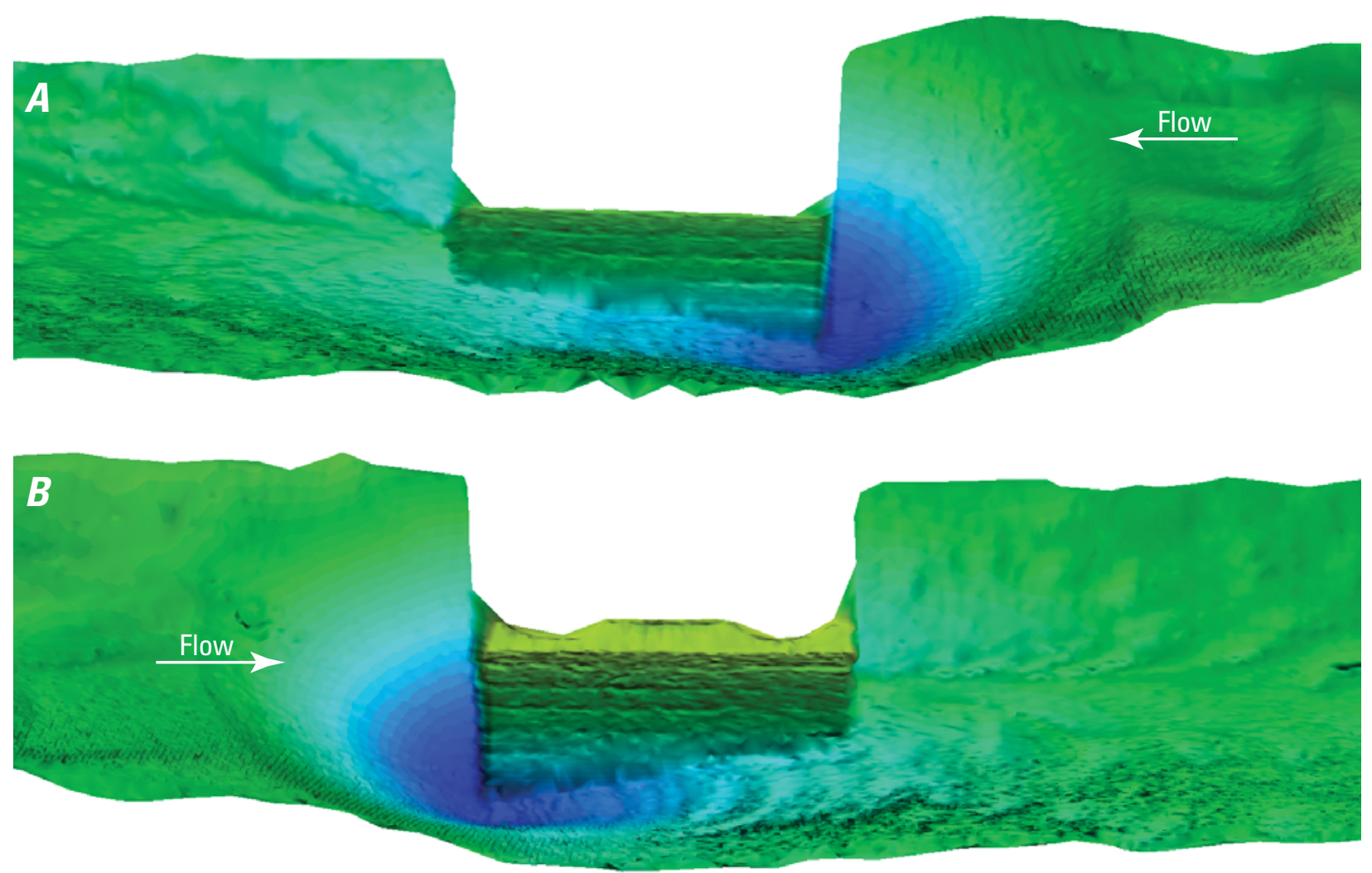

\title{
EXPLANATION
}

\author{
Elevation of point, in feet \\ above the North American \\ Vertical Datum of 1988 \\ $\sigma_{0} \sigma_{8} \sigma_{0} \sigma_{2} \sigma_{\%} \sigma_{20} \sigma_{2} \sigma_{28} \sigma_{3}$
}

Figure 1-3. Shaded triangulated irregular network (TIN) visualization of the channel bed and $A$, left (northwest) side, and $B$, right (southeast) side of main channel pier 5 of structure K0999 on State Highway 41 over the Missouri River at Miami, Missouri. 

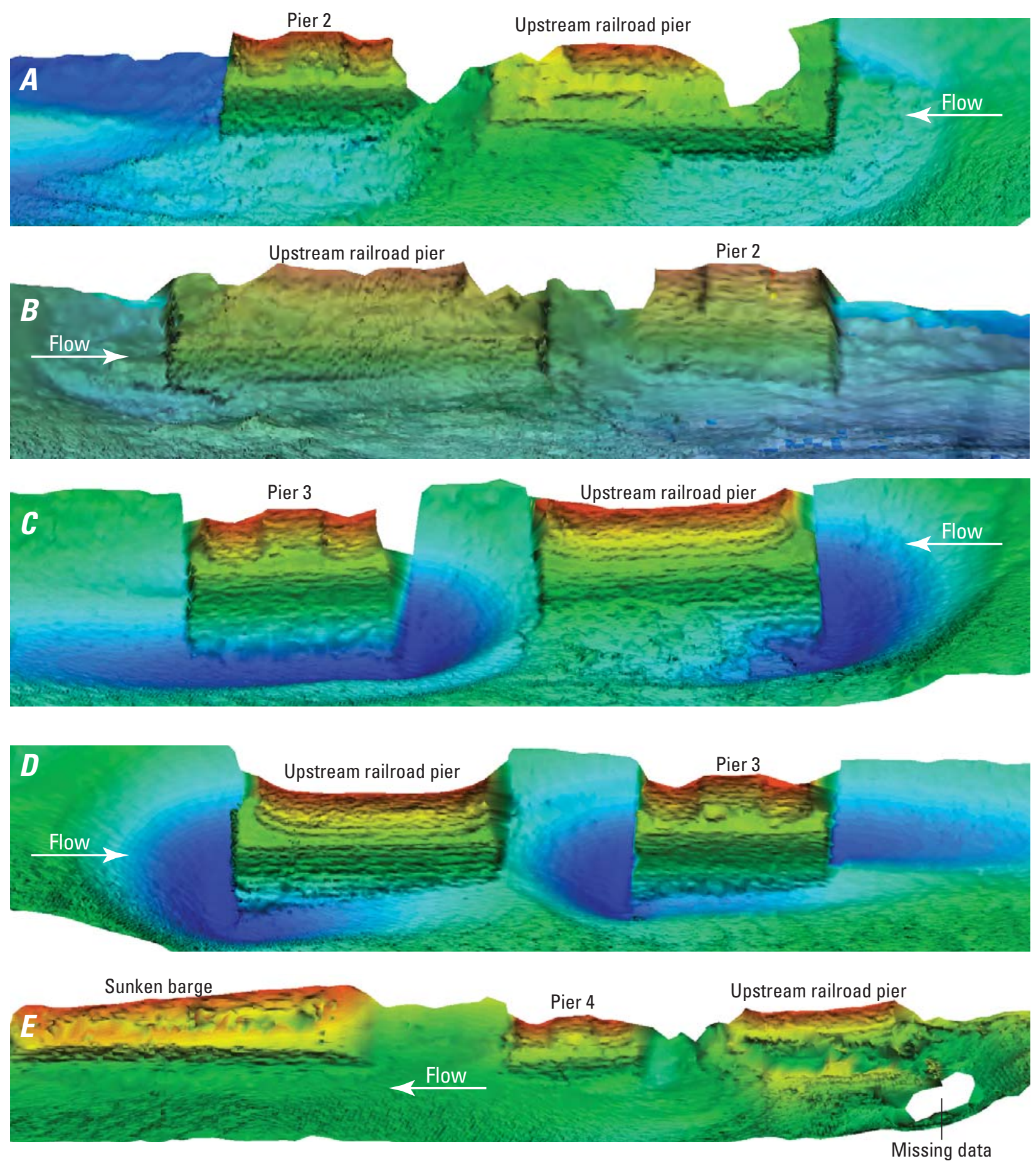

\section{EXPLANATION}

Elevation of point, in feet above the North American Vertical Datum of 1988

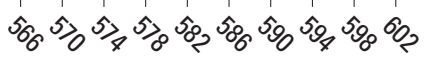

Figure 1-4. Shaded triangulated irregular network (TIN) visualization of the channel bed and $A$, left (east) side, and $B$, right (west) side of main channel pier 2; $C$, left (east) side, and $D$, right (west) side of main channel pier 3; and $E$, left (east) side of main channel pier 4 of structure G0069 on State Highway 240 over the Missouri River at Glasgow, Missouri. 

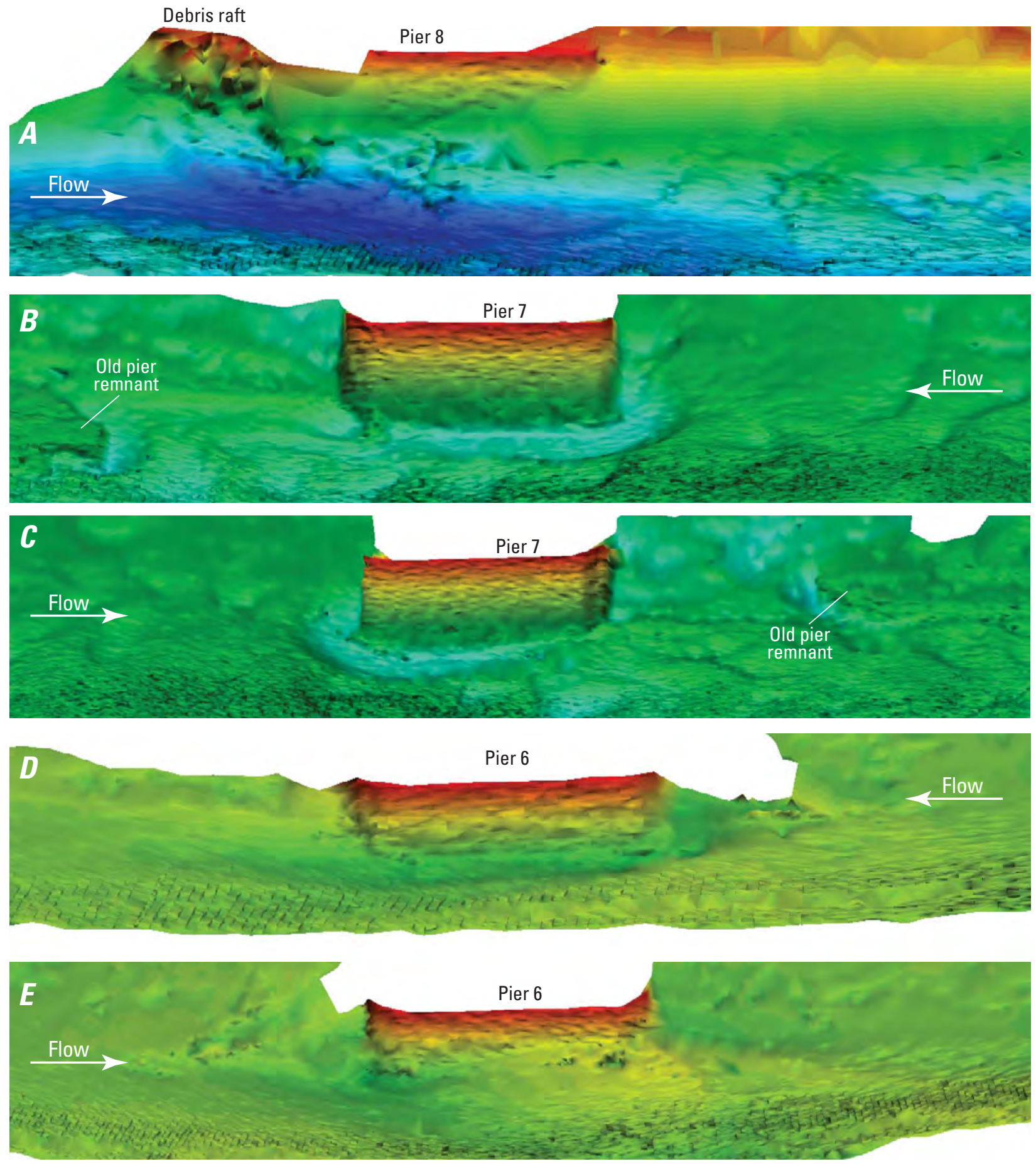

\section{EXPLANATION}

Elevation of point, in feet above the North American Vertical Datum of 1988

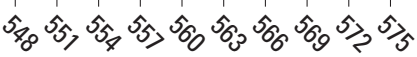

Figure 1-5. Shaded triangulated irregular network (TIN) visualization of the channel bed and $A$, right (south) side of main channel pier 8; $B$, left (north) side, and $C$, right (south) side of main channel pier 7; and, $D$, left (north) side, and $E$, right (south) side of main channel pier 6 of structure A4574 on State Highway 5 over the Missouri River at Boonville, Missouri. 

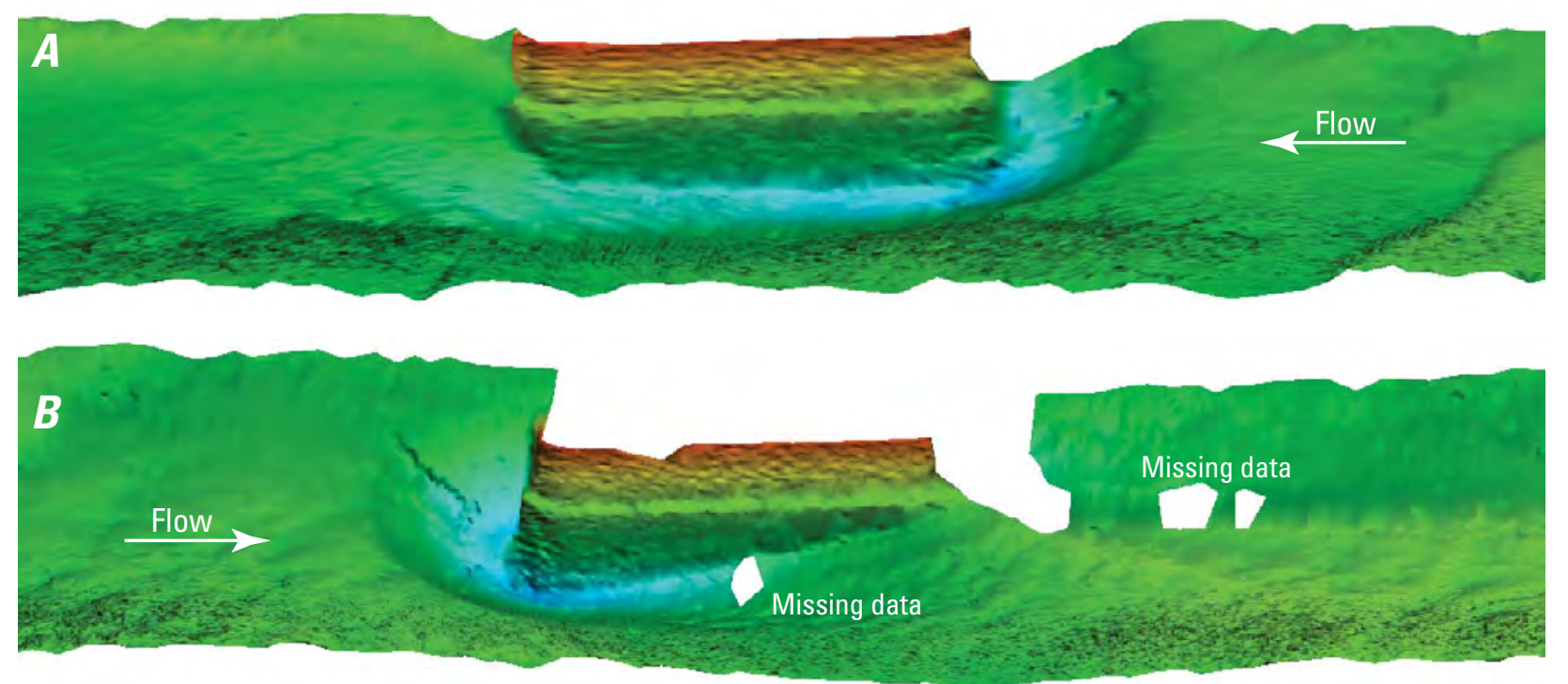

\section{EXPLANATION}

Elevation of point, in feet

above the North American

Vertical Datum of 1988

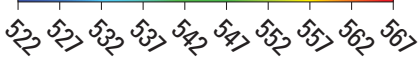

Figure 1-6. Shaded triangulated irregular network (TIN) visualization of the channel bed and $A$, left (northeast) side, and $B$, right (southwest) side of main channel pier 14 of structure L0962 on Interstate 70 over the Missouri River near Rocheport, Missouri. 

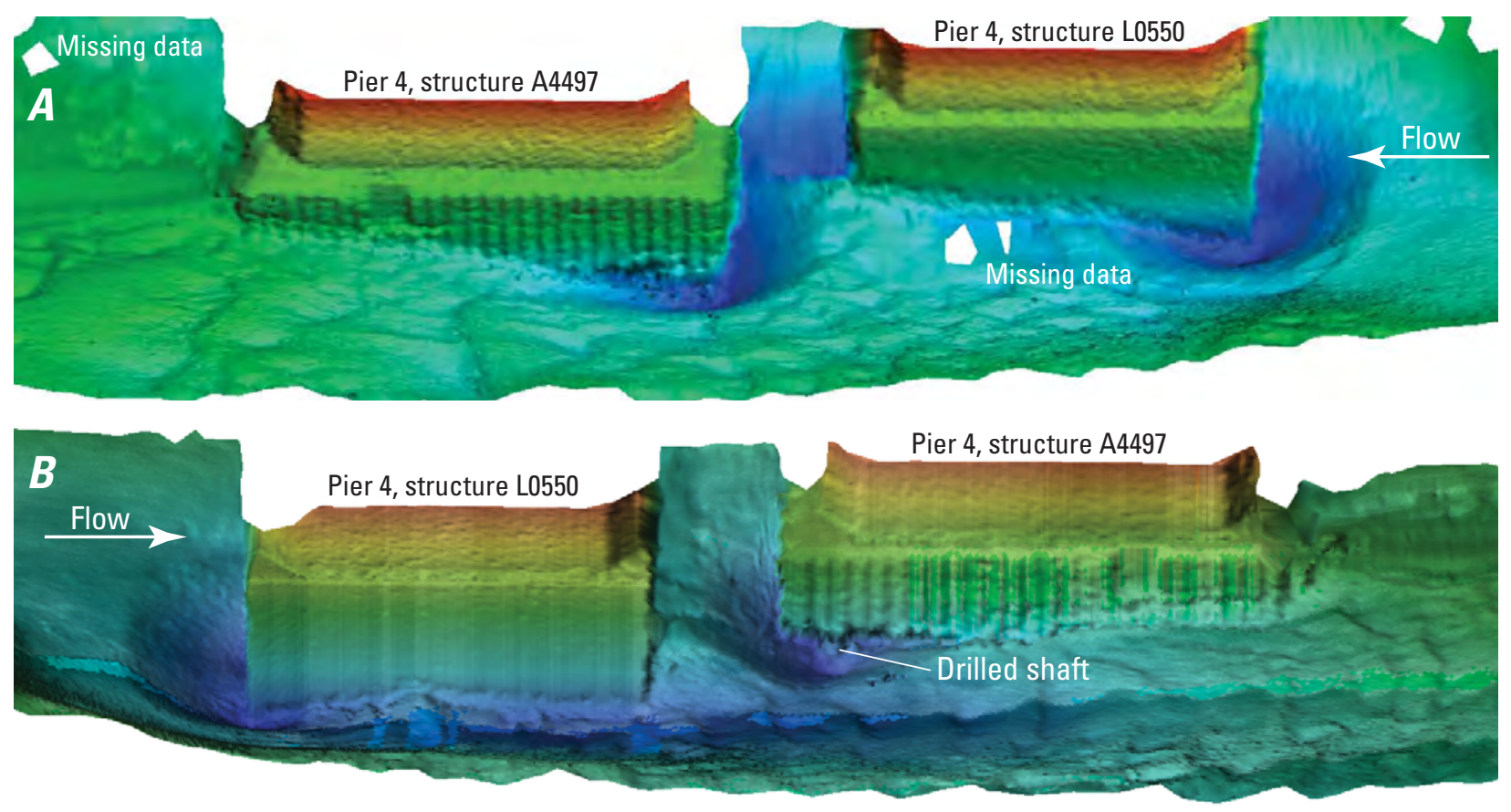

\section{EXPLANATION}

Elevation of point, in feet above the North American Vertical Datum of 1988

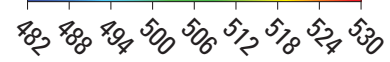

Figure 1-7. Shaded triangulated irregular network (TIN) visualization of the channel bed and $A$, left (northeast) side, and $B$, right (southwest) side of main channel pier 4 of structures L0550 and A4497 on U.S. Highway 54 over the Missouri River at Jefferson City, Missouri. 

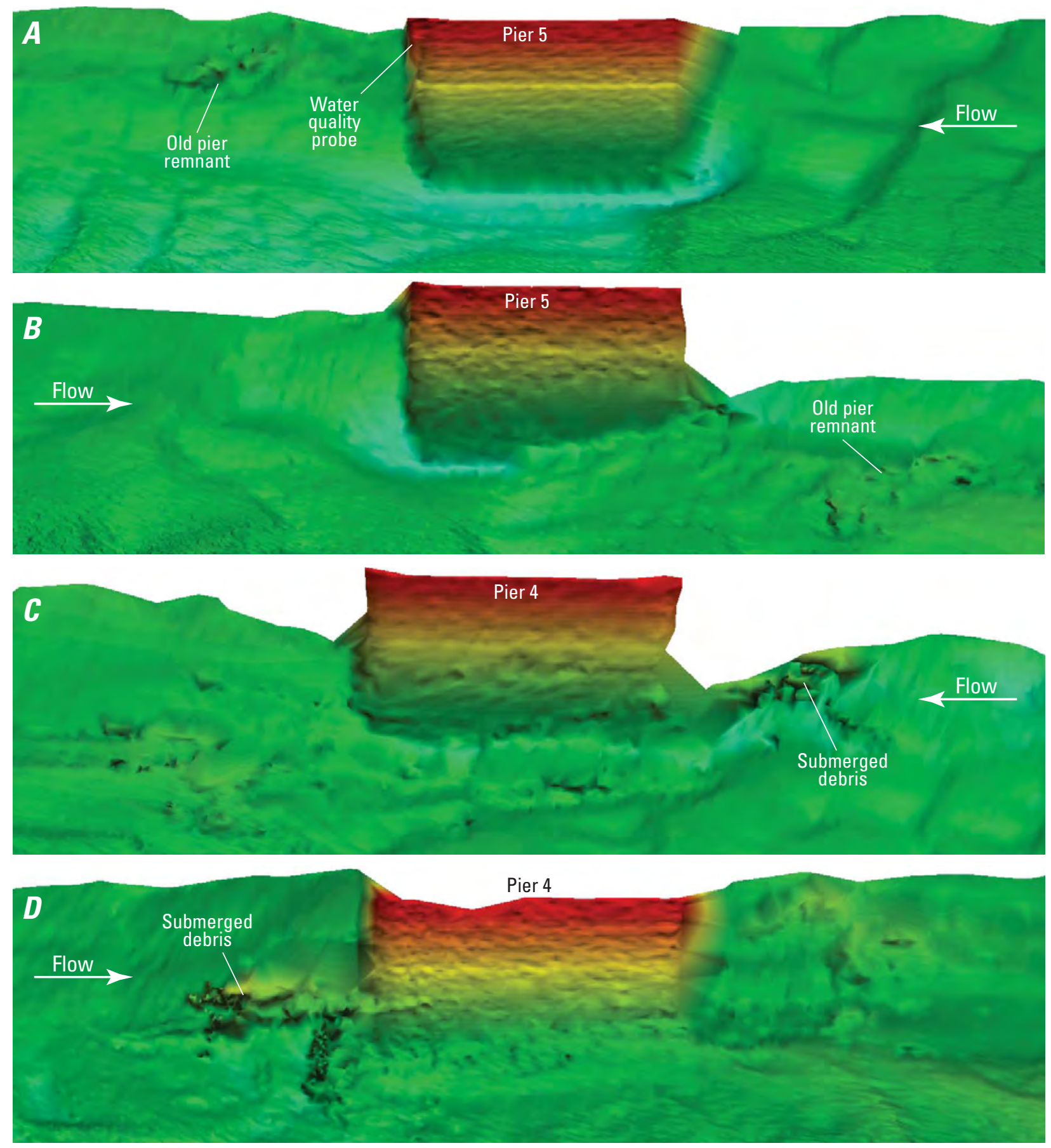

\section{EXPLANATION}

Elevation of point, in feet above the North American Vertical Datum of 1988

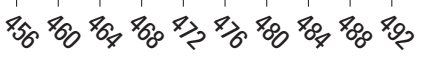

Figure 1-8. Shaded triangulated irregular network (TIN) visualization of the channel bed and $A$, left (northwest) side, and $B$, right (southeast) side of main channel pier 5 ; and, $C$, left (northwest) side, and $D$, right (southeast) side of main channel pier 4 of structure A6288 on State Highway 19 over the Missouri River at Hermann, Missouri. 

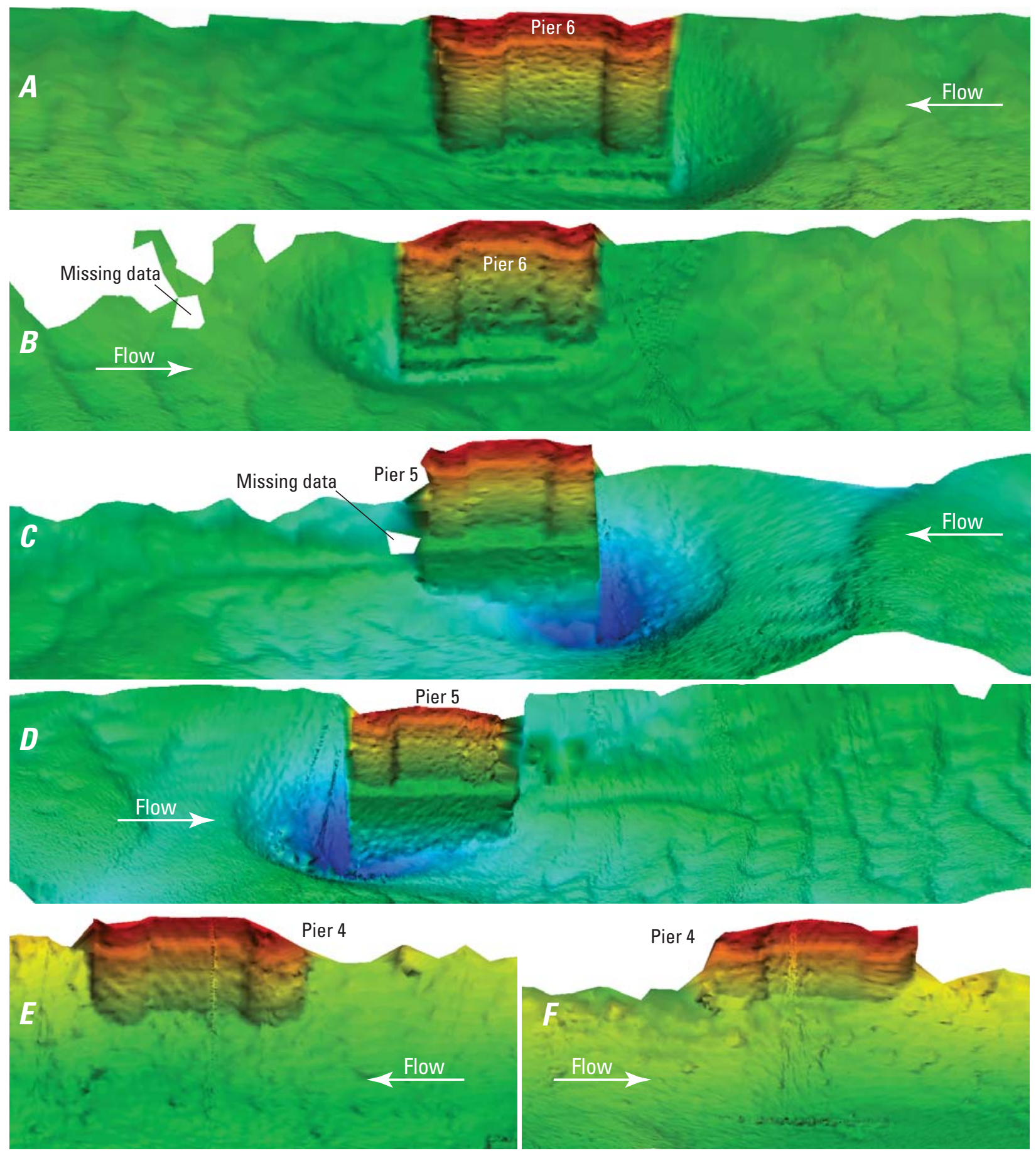

\section{EXPLANATION}

Elevation of point, in feet above the North American

Vertical Datum of 1988

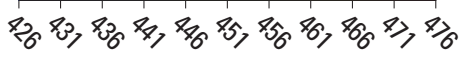

Figure 1-9. Shaded triangulated irregular network (TIN) visualization of the channel bed and $A$, left (northeast) side, and $B$, right (southwest) side of main channel pier $6 ; C$, left (northeast) side, and $D$, right (southwest) side of main channel pier 5 ; and $E$, left (northeast) side, and $F$, right (southwest) side of main channel pier 4 of structure K0969 on State Highway 47 over the Missouri River at Washington, Missouri. 
Publishing support provided by: Rolla Publishing Service Center

For more information concerning this publication, contact: Director, Missouri Water Science Center

U.S. Geological Survey

1400 Independence Road, MS-100

Rolla, M0 65401

(573) 308-3667

Or visit the Missouri Water Science Center Web site at: http://mo.water.usgs.gov/ 


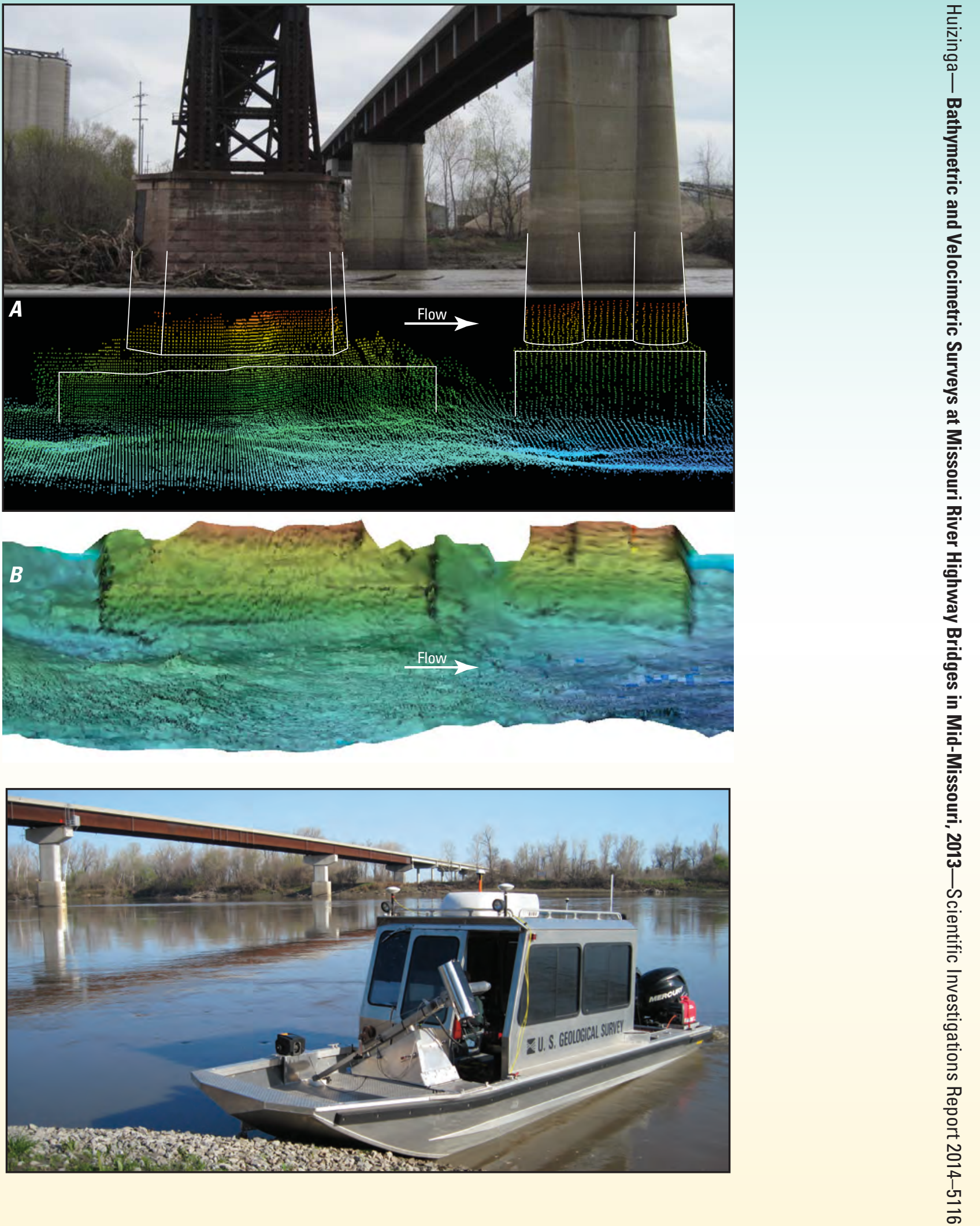

ISSN 2328-0328 (online) 